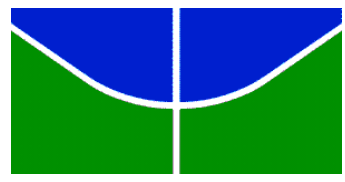

UNIVERSIDADE DE BRASÍLIA

DEPARTAMENTO DE GEOGRAFIA

PROGRAMA DE PÓS-GRADUAÇÃO EM GEOGRAFIA

Aspectos da Morfometria de Drenagem e Produção de Sedimentos em Relação a Variante Chuva x Vazão de Diferentes Trechos da Bacia do Ribeirão do Gama - Distrito Federal nos anos de 2014 a 2015

\author{
Isabela Catarina de Souza
}

Orientador: Dr. Mário Diniz de Araújo Neto 
Instituto de Ciências Humanas

Departamento de Geografia

Programa de Pós-Graduação em Geografia

\author{
UNIVERSIDADE DE BRASÍLIA \\ PÓS-GRADUAÇÃO EM GEOGRAFIA
}

\title{
Aspectos da Morfometria de Drenagem e Produção de Sedimentos em Relação a Variante Chuva x Vazão de Diferentes Trechos da Bacia do Ribeirão do Gama - Distrito Federal nos anos de 2014 a 2015
}

\author{
Isabela Catarina de Souza
}

Dissertação de Mestrado submetida ao Programa de Pós-Graduação em Geografia da Universidade de Brasília, como parte dos requisitos necessários para a obtenção do Grau de Mestre em Geografia, área de concentração Representação Espacial da Dinâmica Territorial e Ambiental.

Aprovado por:

Dr. Mário Diniz de Araújo Neto (Orientador) (GEA - UnB)

Dr. André de Souza Avelar (Examinador externo)

Dr. Osmar Abílio de Carvalho Jr. (GEA - UnB) (Examinador Interno)

Brasília-DF, 30 de novembro de 2015. 
Universidade de Brasília

Instituto de Ciências Humanas

Departamento de Geografia

Programa de Pós-Graduação em Geografia

SOUZA, ISABELA CATARINA DE

Aspectos da Morfometria de Drenagem e Produção de Sedimentos em Relação a Variante Chuva x Vazão de Diferentes Trechos da Bacia do Ribeirão do Gama - Distrito Federal nos anos de 2014 a 2015.

\begin{tabular}{|l|l|}
\hline 1. Bacia Hidrográfica & 2. Erosão \\
\hline 3. Curva-Chave & 4. Hidrossedimentologia \\
\hline I. UnB-GEA & II. \\
\hline
\end{tabular}

É concedida à Universidade de Brasília permissão para reproduzir cópias desta dissertação (tese) e emprestar ou vender tais cópias somente para propósitos acadêmicos e científicos. O autor reserva outros direitos de publicação e nenhuma parte desta dissertação de mestrado (tese de doutorado) pode ser reproduzida sem a autorização por escrito do autor. 


\section{DEDICATÓRIA}

Dedico todo meu trabalho a minha amada mãe Maria das Dores de Souza que sempre está ao meu lado. 


\section{AGRADECIMENTOS}

Os meus agradecimentos, primeiramente vão para Deus, por ter me dado força e paciência para levar este período da minha vida até sua conclusão.

A seguir agradeço minha mãe por ter me ajudo sempre, em todos sentidos, por ter tido paciências nos momentos estressantes, por me aconselhar e nunca desistir de mim.

Agradeço ao meu orientador Mário Diniz pelo auxílio prestado, pela paciência e compreensão.

Aos meus amigos e colegas que me ajudaram, devo dizer que sem o apoio deles não conseguiria finalizar, Raina Santos; Rafaela Silva; Flávio Moreira; Marcelo Aguiar; Bruno Távora; Venícius Juvêncio; Jefferson Martins; Ane Caroline, Renan Smith, Marina Mesquita, Érika Noronha, Ligier Braga e Rafaela Araújo.

Ao Sr. Diogo, Ramon, Cana Verde, Sr. Augusto, Vasco, Daniel, Iara, Luciano, Gustavo, Ronaldo, Sr. Machado, Nice, contar com a presença e o auxílio de vocês na Fazenda Água Limpa deixaram as atividades de campo leves, descontraídas e rápidas.

Agradeço ainda a todos os outros amigos e colegas que não citei, por ter compreendido minha ausência e as vezes meu mal humor, principalmente no final do curso.

Ao meu noivo Sósthenes Vasconcelos por ter me ajudado em algumas partes desta pesquisa, pela paciência, compreensão em alguns momentos, pelo carinho e apoio nos momentos difíceis.

Agradeço ao apoio financeiro e material da CAPES, Programa de Pós-Graduação em Tecnologia Ambiental e Recursos Hídricos do Departamento de Engenharia Civil e Ambiental da Universidade de Brasília - PTHAR-UnB, Departamento de Pós-Graduação em GeografiaUnB e Instituto de Geociência-UnB, a Agência Nacional de Aguas - ANA pela concessão de aparelhos de meteorológicos e apoio em campo; a Companhia de Saneamento Ambiental do Distrito Federal - CAESB e por fim agradeço a Fazenda Experimental Água Limpa da Universidade de Brasília - FAL-UnB. 


\section{RESUMO}

Compreender o comportamento de bacias hidrográficas tem adquirido relevância tanto em âmbito acadêmico quanto socioeconômico, pois, basicamente, são essas unidades geomorfológicas, com seus atributos naturais, que sustentam a vida humana sobre a terra. Dessa forma decidiu-se realizar este estudo hidrossedimentológico na bacia hidrográfica do Ribeirão do Gama, que fornece água e sedimentos para o Lago Paranoá - Distrito Federal. A fim de compreender o comportamento sedimentológico dessa bacia, buscou-se medir a quantidade de sedimentos em suspensão através de coleta de amostras e cálculo de seu volume. Os métodos utilizados nas coletas de sedimento em suspensão foram: Igual Incremento Largura - IIL, Vertical Central e o Amostrador Automático. Nas coletas manuais foram utilizados dois amostradores: USDH-48 e USDH-59. Já na coleta automática utilizou-se o ISCO 6712. Ademais, foram medidos alguns índices morfométricos da área, uma vez que estes auxiliam na dinâmica de transporte dos sedimentos em suspensão. Adicionalmente, obtiveram-se as curvaschave de descarga líquida da bacia hidrográfica do Ribeirão do Gama, assim como de duas de suas sub-bacias (córrego Capetinga e córrego Taquara), a partir das quais calculou-se a carga sedimentar das três bacias hidrográficas. Estes resultados possibilitaram inferir alguns comportamentos hidro-fluviossedimentométricos para a área de estudo, a qual tem sua importância para a qualidade hídrica da bacia do Ribeirão do Gama, para a agricultura local, a geração de energia elétrica, a manutenção da biodiversidade de região, o abastecimento hídrico humano, dentre outros fatores socioeconômicos.

Palavras-Chave: Métodos de Coleta de Sedimento em Suspensão; Transporte de Sedimentos; Assoreamento; Abastecimento Hídrico Humano. 


\begin{abstract}
Understanding physical behavior of river basins has turned into a relevant issue in both academic and socioeconomic level, this Geomorphological unit and its physical atributes, sustains human life and the countries's economies. Thus, the hydrosedimentological study of Ribeirão Gama basin, which is one of the Paranoá Lake - Distrito Federal's major supplier, became much more significant. To achieve project proposal the use of morphometric ratios were necessary in all area, as those interferes in the dynamics which controls the spatial distribution of materials and energy, such as dynamic regime of the flows, presence of unconsolidated sediments in water bodies; in addition it was possible to obtain the ratio curves of Ribeirão Gama's basin, as well as two of its sub-basins (Capetinga and Taquara Streams) in which, based on the collected data, the sediment load of the three watersheds was built. These results allowed inferring some hydro river-sedimentometric behaviors for the quoted area, which, despite being a small area compared to others suppliers basins of Paranoá Lake, its considerable importance for water quality, local agriculture, electric power generation, biodiversity, among other factors.
\end{abstract}

Keywords: Sediment Collection Methods Suspended; Sediment Transport; Silting; Human Leaf Water Supply. 


\section{SUMÁRIO}

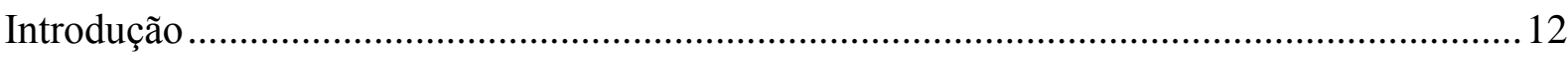

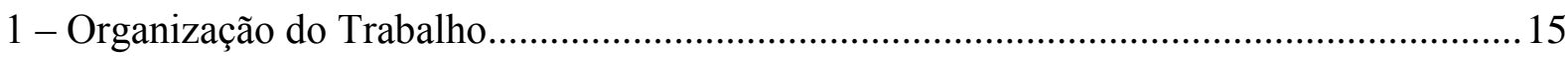

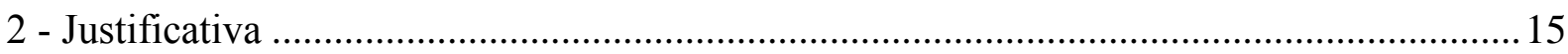

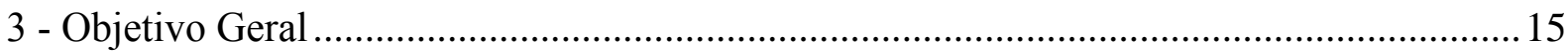

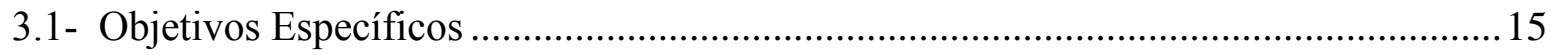

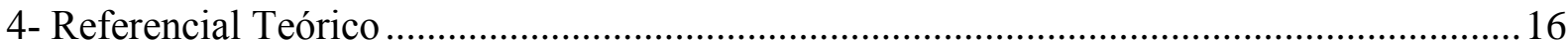

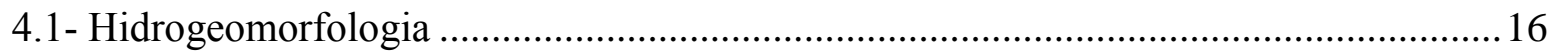

4.1.1 - Análise Morfométrica em Bacias Hidrográficas ................................................... 17

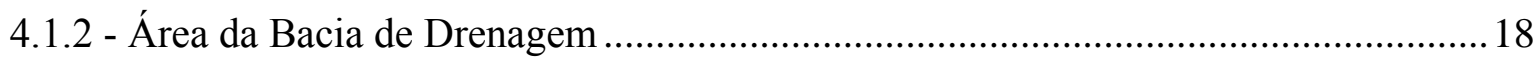

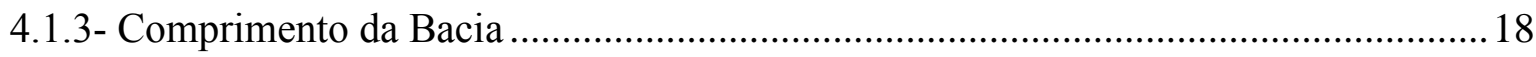

4.1.4 - Hierarquização da Rede de Drenagem ................................................................. 19

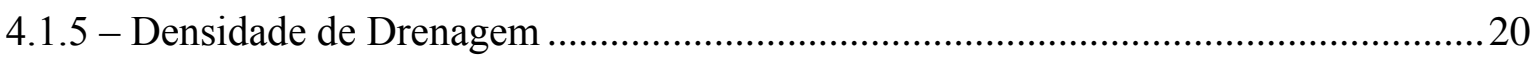

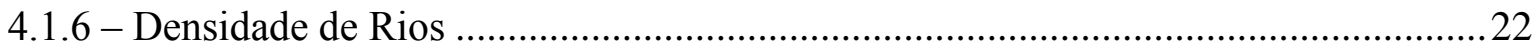

4.1.7 - Coeficiente de Manutenção da Bacia ……............................................................. 22

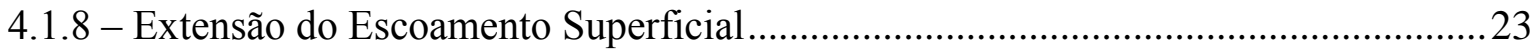

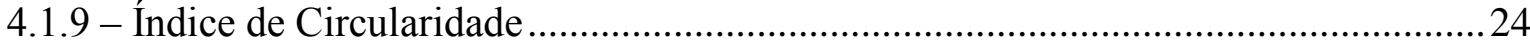

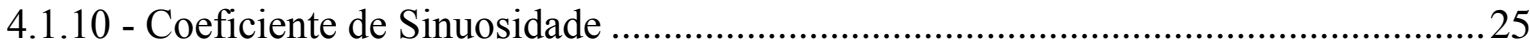

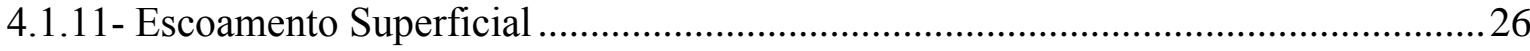

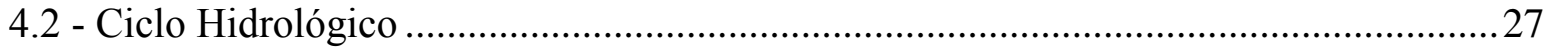

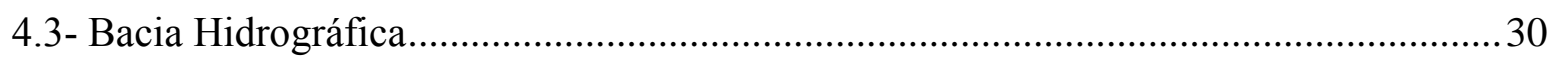

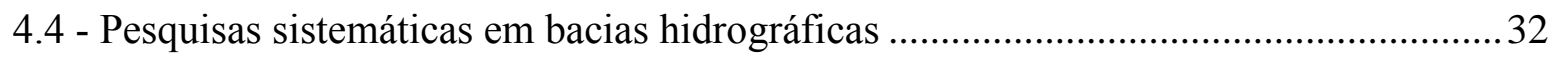

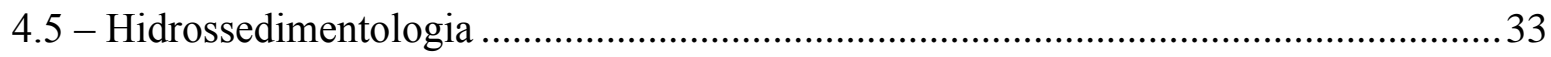

4.6 - Forças Atuantes nas Partículas de Sedimento Durante o Transporte em Suspenção .. 34

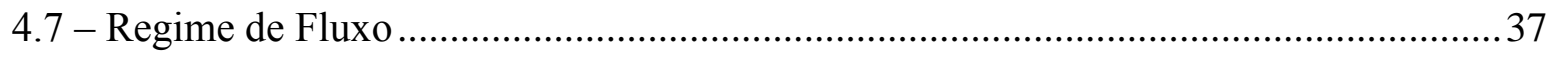

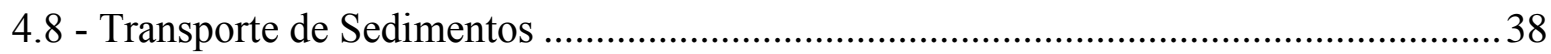

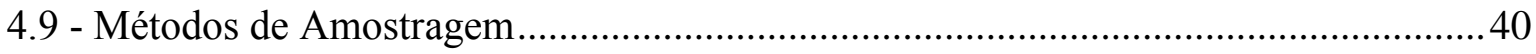




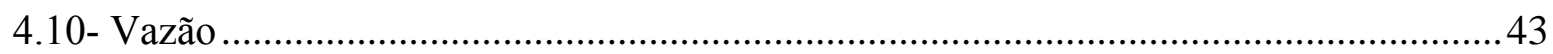

4.11- Curva-Chave de Vazão ....................................................................................... 45

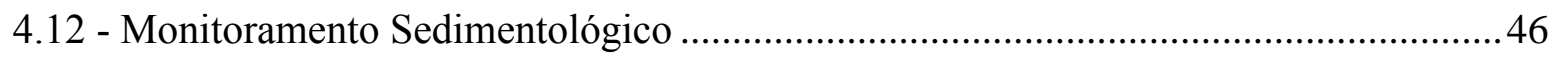

4.13 -Curva-Chave de Sedimentos em Suspensão Instantânea......................................... 47

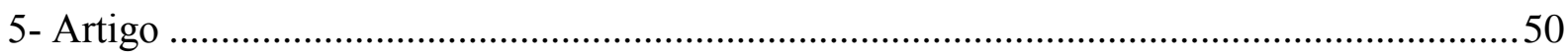

Keywords: Sediment Production; Small basin; Water Resources........................................ 51

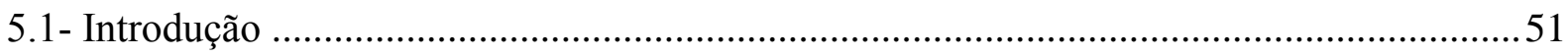

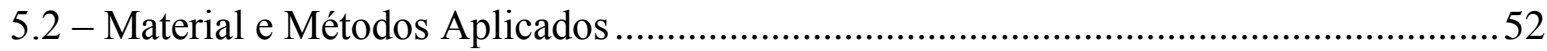

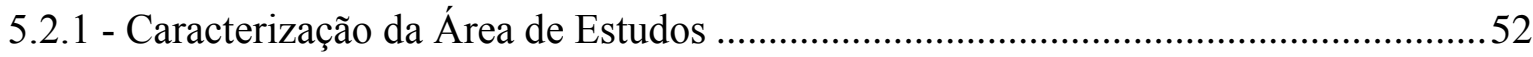

5.2.2 - Aquisição dos Insumos Geoespaciais e Análise Laboratorial das Amostras de

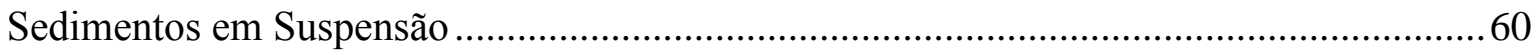

5.2.3 - Curva-Chave Descarga Líquida e Quantidade de Sedimentos em Suspensão ..........61

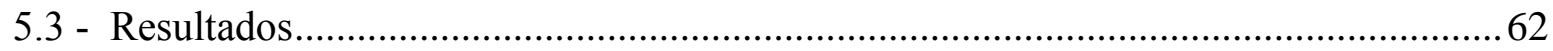

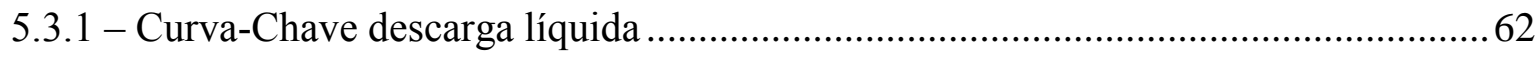

5.3.2 - Resposta pluvio-fluviométrica e sedimentar....................................................... 63

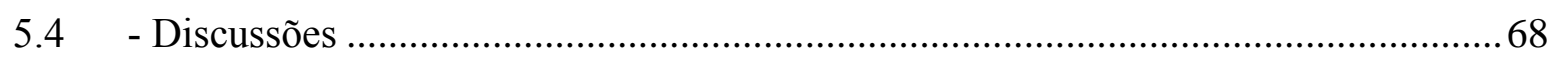

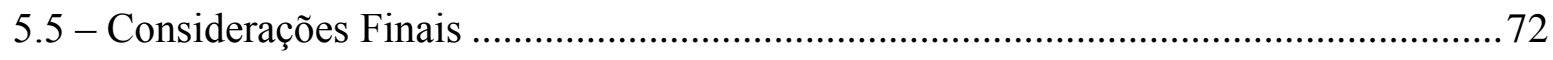

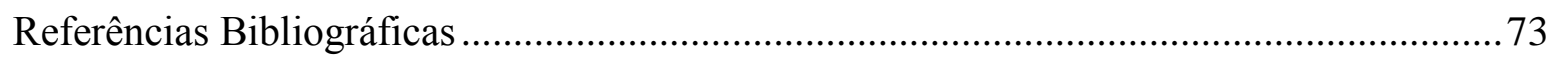

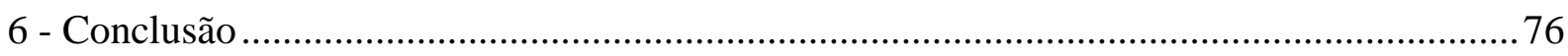

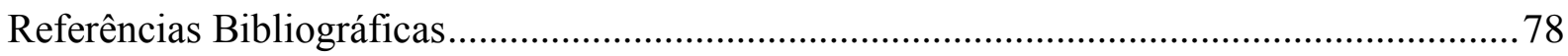

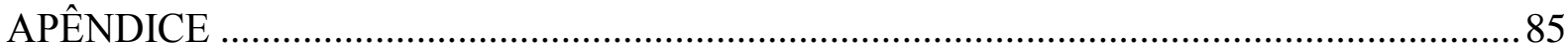

A - Descrição Ampliada dos Materiais e Métodos Utilizados ................................................. 85

A.1 - Obtenção dos Parâmetros Meteorológicos, do Nível e da Vazão nos Trechos Analisados

A.2 - Instrumentalização das Estações Córrego Taquara e FAL - UnB .............................. 87

A.3 - Dificuldades na Coleta dos Dados em Campo ........................................................ 91

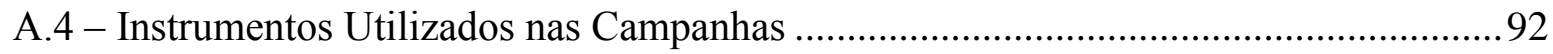

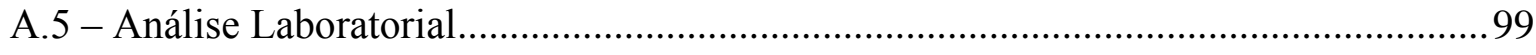


1) Procedimento para Análise Sedimentométrica em Laboratório pelo Método da Filtração 


\section{LISTA DE FIGURAS}

Figura 1: Balanços hídricos climatológicos utilizando dados da normal climatológica da estação

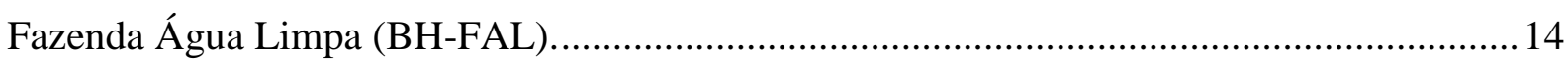

Figura 2: Modelos conceituais de três interações entre a Geomorfologia, Hidrologia e Hidrogeomorfologia: a) sobreposição, b) intersecção e c) nova ciência.............................. 16

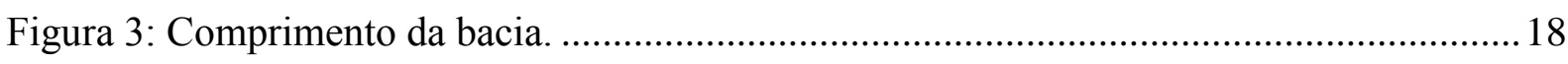

Figura 4: Hierarquização segundo Horton (A) e Strahler (B) . ............................................ 20

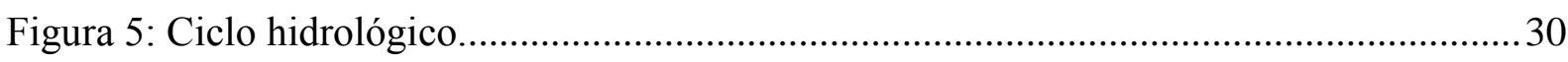

Figura 6: Fluxograma do processo de transporte de sedimento em cursos d'água. ..................34

Figura 7: Forças atuantes Lei de Stokes. Onde: Fg: Força Gravitacional; Fb: Força Ascensional

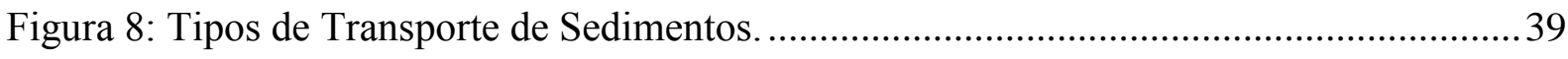

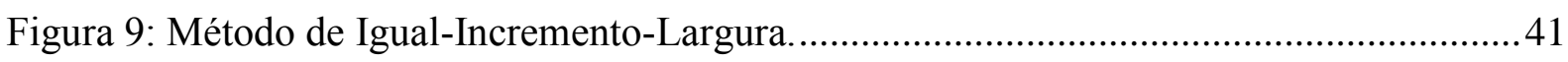

Figura 10: Seção de medição de vazão. L - Comprimento de uma margem a outra; $\mathrm{h}$ - Altura da superfície da lâmina d'água até o leito do canal, hm: Altura média da lâmina d'água.......44 Figura 11: Seção transversal de canal e suas verticais. De A a D - Largura do canal; E a J Pontos das verticais onde serão realizadas as medições da velocidade do fluxo.

Figura 12: Mapa de uso dos solos - Bacia Ribeirão do Gama. Vetorizado na escala: 1:10.000.

Figura 13: Mapa de localização da área de estudos. Bacia do Ribeirão do Gama, com bacia do córrego Capetinga (amarelo) e bacia do córrego Taquara (vermelho).

Figura 14: Média mensal - bacia hidrográfica Ribeirão do Gama - Estação pluviométrica Área Alfa (1979 - 2015).

Figura 15: Média mensal precipitação (01/2014- 02/2015) - bacia hidrográfica do Ribeirão do Gama - Estação pluviométrica - Área Alfa. 55

Figura 16: A - Mapa de declividade - Bacia Ribeirão do Gama. Escala: 1:10.000, escala vertical: 5m. B - Mapa altimétrico - Bacia Ribeirão do Gama. Escala: 1:10.000, escala vertical: 5m. .57 Figura 17: Mapa geológico - bacia hidrográfica do Ribeirão do Gama. Escala: 1:250.000....58 Figura 18: Quantidade e ordem dos canais - Bacia hidrográfica córrego Taquara e córrego Capetinga. 59

Figura 19: Curva-chave exponencial - vazão - Ribeirão do Gama. 63 
Figura 20: Curva-chave exponencial - vazão - córrego Taquara.

Figura 21: Curva-chave exponencial - córrego Capetinga.

Figura 22: Precipitação (mm) - Estação pluviométrica Área Alfa x vazão $\left(\mathrm{m}^{3} / \mathrm{s}\right) \mathrm{x}$ descarga sólida observada em suspensão (ton. $/ \mathrm{km}^{2} / \mathrm{dia}$ ) - Método Igual Incremento Largura e Vertical Central- Ribeirão do Gama.

Figura 23: Precipitação $(\mathrm{mm})$ Estação pluviométrica - córrego Taquara $x$ vazão $\left(\mathrm{m}^{3} / \mathrm{s}\right) \mathrm{x}$ descarga sólida observada em suspensão (ton. $/ \mathrm{km}^{2} / \mathrm{dia}$ ) - Método Igual Incremento Largura e Vertical Central - córrego Taquara.

Figura 24: Precipitação (mm) Estação pluviométrica - Fal_UnB x vazão $\left(\mathrm{m}^{3} / \mathrm{s}\right)$ x descarga sólida observada em suspensão (ton. $/ \mathrm{km}^{2} / \mathrm{dia}$ ) - Método Igual Incremento Largura e Vertical Central- córrego Capetinga.

Figura 25: Curva de resposta da vazão x evento pluviométrico - Estação Área Alfa (23/03/2014

- 14:14 - 26/03/2014 - 00:14 - 1h/1h) - Ribeirão do Gama.

Figura 26: Curva de resposta da vazão x evento pluviométrico - Estação córrego Taquara (24/03/2014 - 24/03/2014 - 15min./15 min.) - córrego Taquara.

Figura 27: Curva de resposta da vazão x evento pluviométrico - Estação FAL - UnB (24/03/2014 - 25/03/2014 - 15min./15 min.) - córrego Capetinga.

Figura 28: Resposta vazão x Qss amostrador automático.

Figura 29: Correlação vazão x Qss (ton. $/ \mathrm{km}^{2} / \mathrm{dia}$ ) - Método Igual Incremento Largura Ribeirão do Gama. .68

Figura 30: Correlação vazão $\left(\mathrm{m}^{3} / \mathrm{s}\right)$ x Qss (ton./L/min.) Método amostrador automático Ribeirão do Gama. .68

Figura 31: Estações utilizadas na pesquisa. 86

Figura 32: Esquema de posicionamento do pluviômetro em relação aos obstáculos. 87

Figura 33: Escolha das árvores para confecção das pontes - córrego Taquara e Capetinga. ... 89

Figura 34: Ponte córrego Taquara. 89

Figura 35: Instalação estação pluviométrica- fluviométrica - córrego Taquara. 89

Figura 36: Técnicos da ANA auxiliando na instalação da estação córrego Taquara. 89

Figura 37: Instalação radar e ponte concluída - córrego Capetinga. 89

Figura 38: Instalação estação pluviométrica e fluviométrica - córrego Capetinga. .89

Figura 39: Estação FAL - UnB concluída. 90

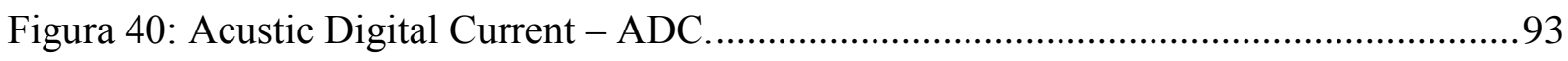

Figura 41: Acustic Digital Current - ADC - OTT Qlinner 2 ............................................. 94

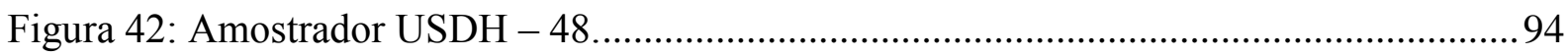


Figura 43: Amostrador USDH-59.

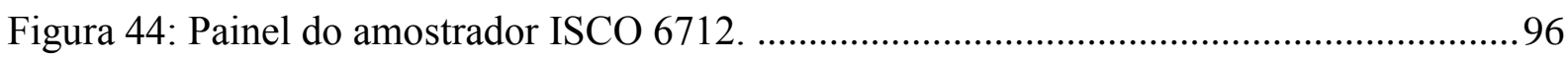

Figura 45: Amostrador instalado no Ribeirão do Gama............................................................96

Figura 46: Resultado após um evento de pluviométrico. .......................................................96

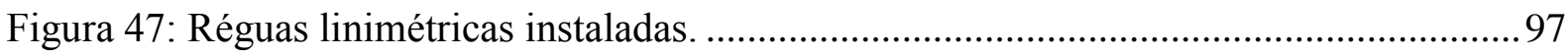

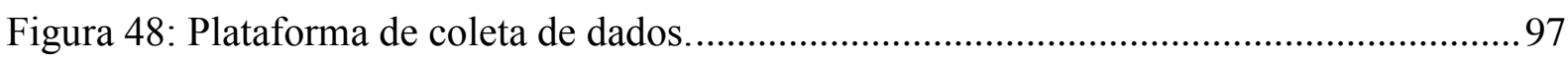

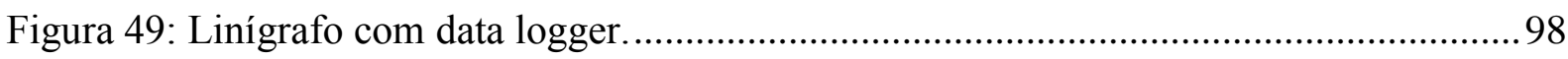

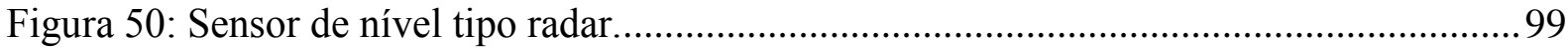

Figura 51: Estação para filtragem completa....................................................................... 101

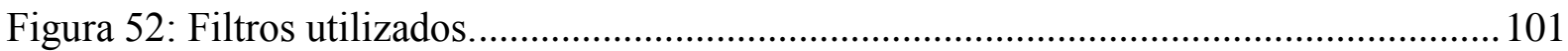

Figura 53: Petris com amostras filtradas (Ribeirão do Gama são as escuras e as mais claras são

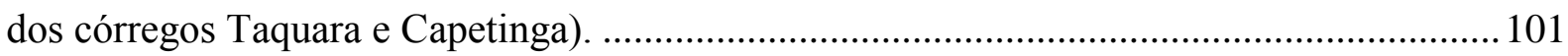

Figura 54: Retirada dos sedimentos sobrenadante. ........................................................ 101 


\section{LISTA DE TABELAS}

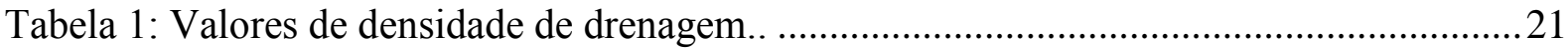

Tabela 2: Classificação da sinuosidade da bacia hidrográfica.. ...............................................26

Tabela 3: Velocidade e tempo gasto para decantação de partículas de areia fina, silte e argila.

Tabela 4: Tipo de medições de sedimentos, suas descrições e equipamentos mais utilizados nas coletas realizadas no Brasil. 42

Tabela 5: Porcentagem dos usos de solos das bacias hidrográficas estudadas. 53

Tabela 6: Porcentagem das classes de solos para cada Bacia hidrográfica. 56

Tabela 7: Índices morfométricos para as bacias hidrográficas estudadas. 59

Tabela 8: Demonstrativo do número de coletas, período de coleta e tipo de amostrador utilizado. 61

Tabela 9: Índices de ajuste da curva-chave de descarga líquida - bacias hidrográficas estudadas. 


\section{Introdução}

Os diversos processos integrados ao longo do tempo que atuam sob a superfície terrestre (geológico, geomorfológico, hidrológico, pedológico, ecológico, antrópico) resultam em variadas feições topológicas, tais como chapadas, morros, escarpas, planícies, rios, voçorocas, dentre outras, as quais são caracterizadas por tamanho, forma, orientação e posição geográfica peculiares (MACMILLAN e SHARY, 2009).

Essas feições apresentam importante papel na natureza, pois interferem sobre as dinâmicas que controlam a distribuição espacial de materiais e energia, como por exemplo, regime da dinâmica da água, transporte de sedimentos, desenvolvimento do solo, presença de sedimentos não consolidados, áreas com maior susceptibilidade à erosão, entre outros elementos. Devido ao acelerado avanço do domínio do homem sobre o meio natural, com a construção de edificações, alguns ambientes foram e continuam sendo desestabilizados por falta de adequado manejo dos recursos naturais.

O planejamento e o licenciamento ambientais são indispensáveis, no sentido de compatibilizar os vários usos de água, solo e vegetação, a fim de viabilizar os diferentes setores produtivos, monitorando a quantidade e a qualidade dos recursos hídricos e naturais, melhorando os níveis de eficiência global dos usos (PAZ et al. 2000).

Desta forma, a fim de auxiliar a compreensão do comportamento ambiental e hídrico de uma bacia hidrográfica contribuinte do Lago Paranoá, visando a melhora do uso dos recursos hídricos do Distrito Federal, optou-se, em virtude da proximidade, facilidade de acesso e de instrumentação, por estudar a bacia hidrográfica do Ribeirão do Gama - Brasília - Distrito Federal (DF), localizada ao sul do DF entre as coordenadas de $15^{\circ} 50^{\prime}$ e $16^{\circ}$ de latitude sul e $47^{\circ}$ $50^{\prime}$ e $48^{\circ}$ de longitude oeste, com área de aproximadamente $147,81 \mathrm{~km}^{2}$, na qual se ressalta a característica de uso agricultural da água.

As coletas de dados hidrossedimentológicos foram realizadas em duas estações pluviofluviométricas (córrego Capetinga e córrego Taquara) e uma fluviométrica (Gama Base-Aérea). Esta última foi implantada pela Companhia de Saneamento Ambiental do Distrito Federal CAESB na década de 1970, desde quando permanece sob os cuidados da Companhia. As outras duas estações foram instaladas pelo Laboratório de Geografia Física - LAGEF em parceria com a Agência Nacional de Águas - ANA juntamente com a CAESB e Fazenda Experimental Água Limpa - FAL-UnB.

De acordo com Carmo (2001) o posicionamento do DF na porção central do Planalto Central e sua altitude fazem com que essa unidade da federação seja um dos divisores naturais 
de águas das três principais bacias hidrográficas do Brasil - bacia do Paraná, bacia do São Francisco e bacia do Araguaia-Tocantins. O DF sofre escassez de água, justamente porque age como divisor de águas, e não como receptor de águas, o que torna mais importantes os cuidados com os recursos hídricos existentes, dentre os quais se destaca o Lago Paranoá, que, mesmo em escala reduzida, é utilizado para geração de energia e, conforme exposto no Projeto do Sistema de Abastecimento de Água com Captação no Lago Paranoá (CONSÓRCIO THEMAGNA, 2009) será utilizado como fonte de umidade, abastecimento de água e lazer para a população local.

O estudo da bacia hidrográfica do Ribeirão do Gama é estrategicamente convidativo, dado que ela abrange áreas de usos variados: áreas de preservação/conservação (Reserva Ecológica do IBGE, Fazenda Experimental da UnB - Água Limpa e Estação Ecológica do Jardim Botânico), áreas urbanizadas (setor de mansões do Park Way), áreas agrícolas (Núcleo Rural Vargem Bonita e Núcleo Rural do Córrego da Onça, o primeiro considerado um importante polo de abastecimento de produtos hortifrutigranjeiros em Brasília) - e Áreas de Relevante Interesse Ecológico (ARIE's dos córregos Capetinga e Taquara) (Carvalho et al, 2001).

Em relação aos aspectos físicos da bacia hidrográfica do Ribeirão do Gama, tem-se que a margem esquerda é predominantemente composta pela unidade Ardósia, local onde se instalou o Setor de Mansões do Park Way e a área entre os Córregos do Cedro e Mato Seco está urbanizada; esse lado da bacia é também onde se localiza um importante polo de abastecimento de hortifrutigranjeiros em Brasília, os Núcleos Rurais da Vargem Bonita e do Córrego da Onça (CARVALHO et al., 2001). Já a margem direita, composta pela unidade geológica do Metarritimito Arenoso, é mais preservada, pois abriga a Reserva Ecológica do IBGE, a Fazenda Experimental da UnB - Água Limpa e a Estação Ecológica do Jardim Botânico; estas áreas permitem a maior preservação dessa porção da bacia.

O clima do Distrito Federal é composto por duas estações bem definidas: o período de maio a setembro é caracterizado por ser seco, e o de outubro a abril por ser úmido; neste último a amplitude térmica varia menos, pois as máximas mantêm-se e as mínimas se elevam (BARROS, 2003).

Conforme Carvalho (2012), o regime das chuvas no Distrito Federal caracteriza-se por precipitações que variam entre 1.500 e $1.750 \mathrm{~mm} / \mathrm{ano}$, com média em torno de $1.600 \mathrm{~mm} / \mathrm{ano}$, alcançando em janeiro - no verão - seu maior índice pluviométrico, que é de $320 \mathrm{~mm} / \mathrm{mês}$, e durante os meses de junho, julho e agosto - no inverno - os menores índices, chegando à média mensal total da ordem de $50 \mathrm{~mm} / \mathrm{mês}$. Conforme Santos et al. (2001) o balanço hídrico vem se 
alterando, ocorrendo atraso no início do período com excedente hídrico, que passou de outubro para novembro, refletindo nas taxas de precipitação; já o período de deficiência hídrica é antecipado em um mês. Os pesquisadores concluem que há antecipação e prolongamento do período de deficiência hídrica na região da Fazenda Água Limpa.

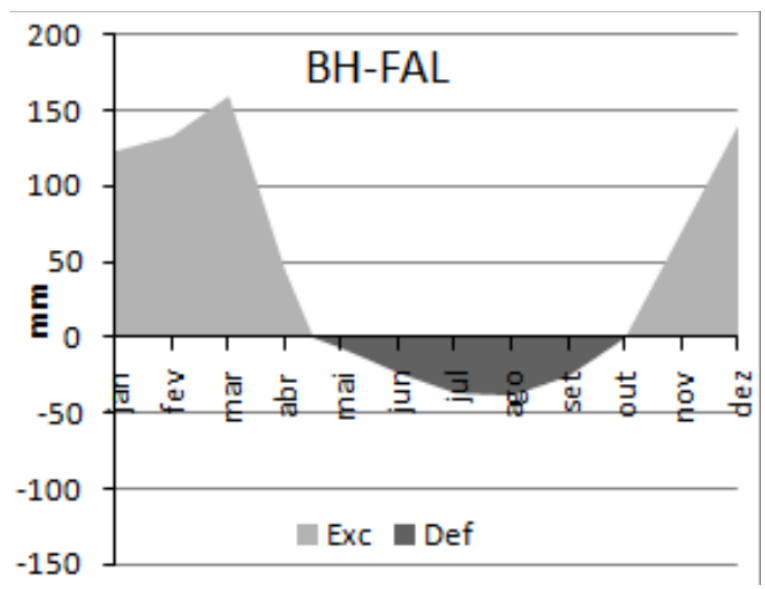

Figura 1: Balanços hídricos climatológicos utilizando dados da normal climatológica da estação Fazenda Água Limpa (BH-FAL). Fonte: Santos et. al. 2001.

A geologia da região da bacia hidrográfica do Ribeirão do Gama apresenta o Grupo Paranoá, da Idade Meso/Neoproterozóica (1.300 a 1.100 milhões de anos atrás), sendo caracterizada por Ardósias e Metarritimito Arenosos (FREITAS-SILVA, 1998).

$\mathrm{Na}$ sua geomorfologia, predominam os Pediplanos, Superfícies Residuais de Aplainamento nas cotas mais elevadas, Depressões Interplanálticas e Planícies (CODEPLAN, 1984). Quanto à formação pedológica da área de estudos, tem-se o predomínio do Latossolo Vermelho, Latossolo Vermelho-Amarelo, Cambissolo, Gleissolos e Laterita. Entretanto, afirma-se que para essa região a combinação Latossolo Vermelho-Escuro, Latossolo VermelhoAmarelo e Cambissolo são as mais abundantes (MOURA, 2008).

Esta pesquisa obteve auxílio financeiro e material das seguintes instituições: Coordenação de Aperfeiçoamento de Pessoal de Nível Superior - CAPES, Programa de PósGraduação em Tecnologia Ambiental e Recursos Hídricos do Departamento de Engenharia Civil e Ambiental da Universidade de Brasília - PTHAR-UnB, Departamento de PósGraduação em Geografia-UnB, Fazenda Experimental Água Limpa - FAL-UnB e Instituto de Geociência-UnB. 


\section{1 - Organização do Trabalho}

Este trabalho foi organizado no formato de artigo, intitulado "Aspectos da Morfometria de Drenagem e Produção de Sedimentos em Relação a Variante Chuva x Vazão de Diferentes Trechos da Bacia do Ribeirão do Gama - Distrito Federal nos anos de 2014 a 2015". Entretanto, em antecedência, há um referencial teórico para embasar a construção do artigo e uma versão estendida dos procedimentos metodológicos, a fim de deixar claro para o leitor todos os passos desenvolvidos durante a pesquisa.

\section{2 - Justificativa}

O estudo do potencial sedimentológico de uma bacia hidrográfica é de suma importância e indispensável para lidar com os problemas e objetivos relacionados à utilização da água (EDWARDS e GLYSSON, 1999). O estudo desta e das outras variáveis pesquisadas nesse trabalho são relevantes, pois abordam diretamente a qualidade e disponibilidade dos recursos hídricos disponíveis para as áreas limítrofes à bacia do Ribeirão do Gama e para o Distrito Federal vislumbrando a possibilidade de o Lago Paranoá abastecer água para a população do DF (CONSÓRCIO THEMAGNA, 2009).

\section{3 - Objetivo Geral}

O objetivo principal desta pesquisa foi compreender o comportamento fluviosedimentológico da bacia hidrográfica do Ribeirão do Gama e de duas de suas sub-bacias, a partir de estudos e medições regulares da vazão e da descarga sedimentar em suspensão.

\section{1- Objetivos Específicos}

- Estudar as diversidades morfométricas da bacia do Ribeirão do Gama, procurando identificar padrões erosivos que possam auxiliar, de forma secundária, a descrição e explicação do processo de transporte de sedimentos.

- Estudar sistematicamente e de forma automatizada o comportamento hidrossedimentológico da bacia do Ribeirão do Gama, bem como das sub-bacias tributárias do Capetinga e Taquara. 
- Comparar diferentes técnicas para o estudo da vazão e carga sedimentar na estação de coleta de dados da bacia do Ribeirão do Gama.

\section{4- Referencial Teórico}

\section{1- Hidrogeomorfologia}

De acordo com Scheidegger (1973), Christofoletti (1981) e Tucci (1993), a geomorfologia é a ciência que estuda as formas de relevo, que representa a expressão espacial de uma superfície, compondo as diferentes configurações da paisagem morfológica, as quais recebem influência direta da ação da água em seu modelamento. A esculturação do relevo e da topografia do leito dos rios se dá pela dinâmica hídrica, originada pelo ciclo hidrológico. A água exerce a função de desagregadora de partículas sedimentares e de transportadora dos sedimentos removidos até os canais, onde serão carreados ou depositados, conforme o tamanho e o peso das partículas (CHRISTOFOLETTI, 1981).

Mediante o estudo dos conceitos de Hidrogeomorfologia, Goerl et al. (2012) em sua análise propuseram três modelos da relação entre a Hidrologia e Geomorfologia, são eles:
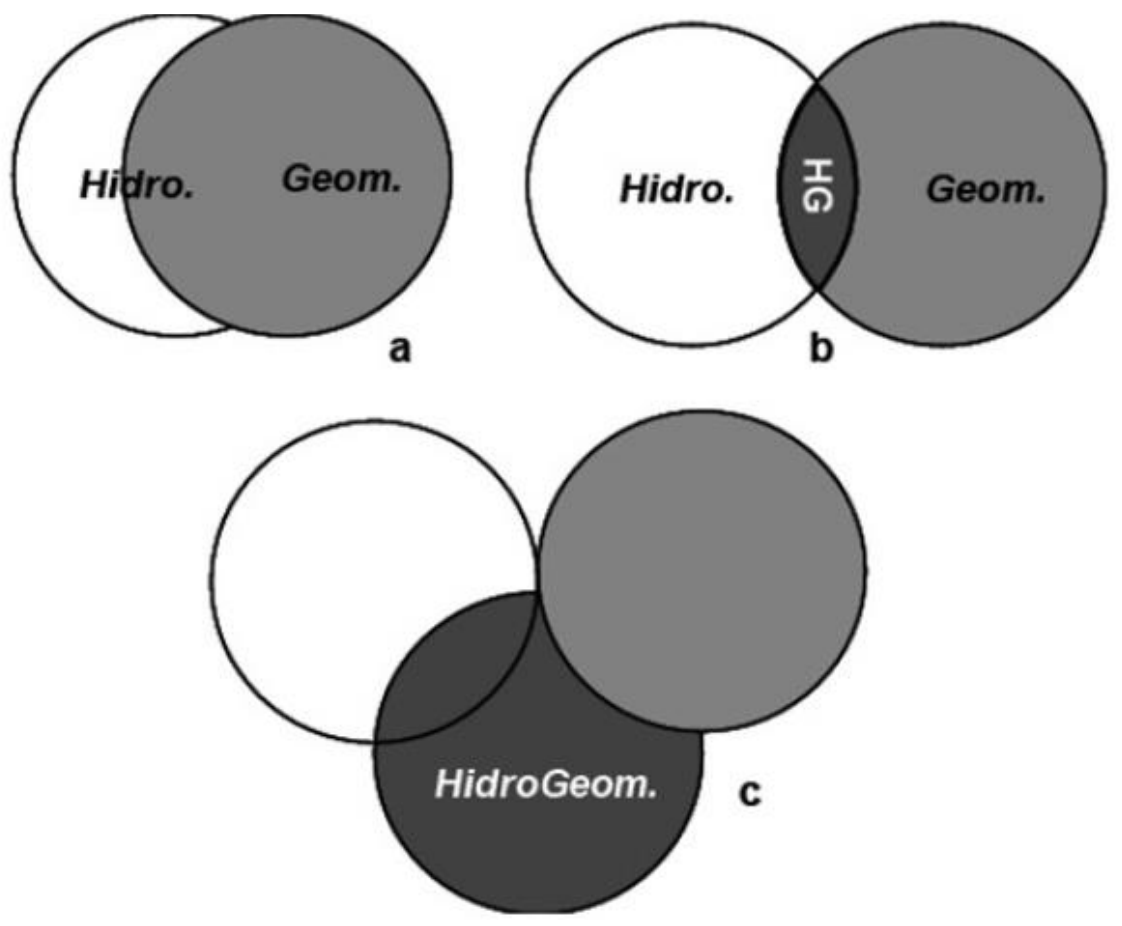

Figura 2: Modelos conceituais de três interações entre a Geomorfologia, Hidrologia e Hidrogeomorfologia: a) sobreposição, b) intersecção e c) nova ciência. Fonte: Goerl, 2012. 
Pela (Figura 02) observa-se a evolução em respeito à ciência Hidrogeomorfologia, em que, no quadro $a$, era tradada como uma ciência superposta à ciência hidrologia e geomorfologia, ou seja, algum estudo permeando entre uma e outra ciência, ora pertencente a hidrologia ora a geomorfologia, que aplicam métodos semelhantes, mas sem necessariamente haver interface entre elas. $\mathrm{O}$ modelo $b$ trata da intersecção das duas ciências, resultando a Hidrogeomorfologia comum as duas outras, entretanto o limiar de separação parece ser bastante tênue. Por último, tem-se o modelo $c$, que trata da autonomia da Hidrogeomorfologia como ciência propriamente dita, a qual influencia e é influenciada por elementos da geomorfologia, da hidrologia, mas também é capaz de sustentar seus embasamentos.

Por este viés surgiram estudos relacionados as influências geomorfológicas sobre a hidrossedimentologia de bacias hidrográficas, os quais se materializam na morfometria de áreas de estudos, pois, as características morfológicas interferem na determinação do comportamento hidrológico das bacias.

\subsection{1 - Análise Morfométrica em Bacias Hidrográficas}

O iniciador deste tipo de análises foi Robert Elmer Horton na década de 1940, o qual visava entender a configuração e a evolução das bacias e de suas redes de drenagem. As pesquisas que envolvem estes índices são classificadas como pesquisas quantitativas de bacias hidrográficas, pois compreendem e representam as bacias na forma de índices numéricos, tal como índice de eficiência de drenagem, ordem da drenagem, forma da bacia, índice de sinuosidade, altimetria, quantidade de canais, dentre outras variáveis morfométricas passíveis de aferição.

Segundo Christofoletti (1980) a análise morfométrica de bacias hidrográficas é a análise quantitativa da configuração dos elementos do modelado superficial que geram sua expressão e configuração espacial. Este sendo composto pelo conjunto das vertentes e canais que compõem o relevo, caracterizado por valores correspondem aos atributos medidos das bacias hidrográficas.

Os resultados aferidos destas variáveis são considerados importantes insumos para o auxílio na verificação da produção de sedimentos, compreensão do comportamento hidrológico, auxílio nas políticas de gestão ambiental, além de revelar indicadores físicos específicos para as bacias analisadas (CHRISTOFOLETTI, 1980; TONELLO, 2006; TEODORO, 2007). 


\subsection{2 - Área da Bacia de Drenagem}

Esta é a variável a ser verificada em primeiro, pois por meio dela será possível compreender as dimensões das respostas das outras variáveis, uma vez que permitirá saber se a bacia estudada é pequena, média ou grande. Como conceito de área da bacia tem-se que é o traçado do contorno de uma área drenada, partindo-se da porção mais elevada (CHRISTOFOETTI, 1980; GUIMARÃES, 2012).

A importância deste dado dá-se pelo fato de possibilitar definir a potencialidade hídrica de uma bacia hidrográfica e constitui-se, ainda, em elemento básico para o cálculo de outras características físicas da bacia, tal como densidade de drenagem, densidade de rios, índice de circularidade, comprimento da bacia dentre outros.

\subsection{3- Comprimento da Bacia}

O comprimento da bacia está diretamente relacionado com a área, pois compreende a distância média, em linha reta, entre a foz e o ponto mais alto situado ao longo do perímetro (CHRISTOFOLETTI, 1980).

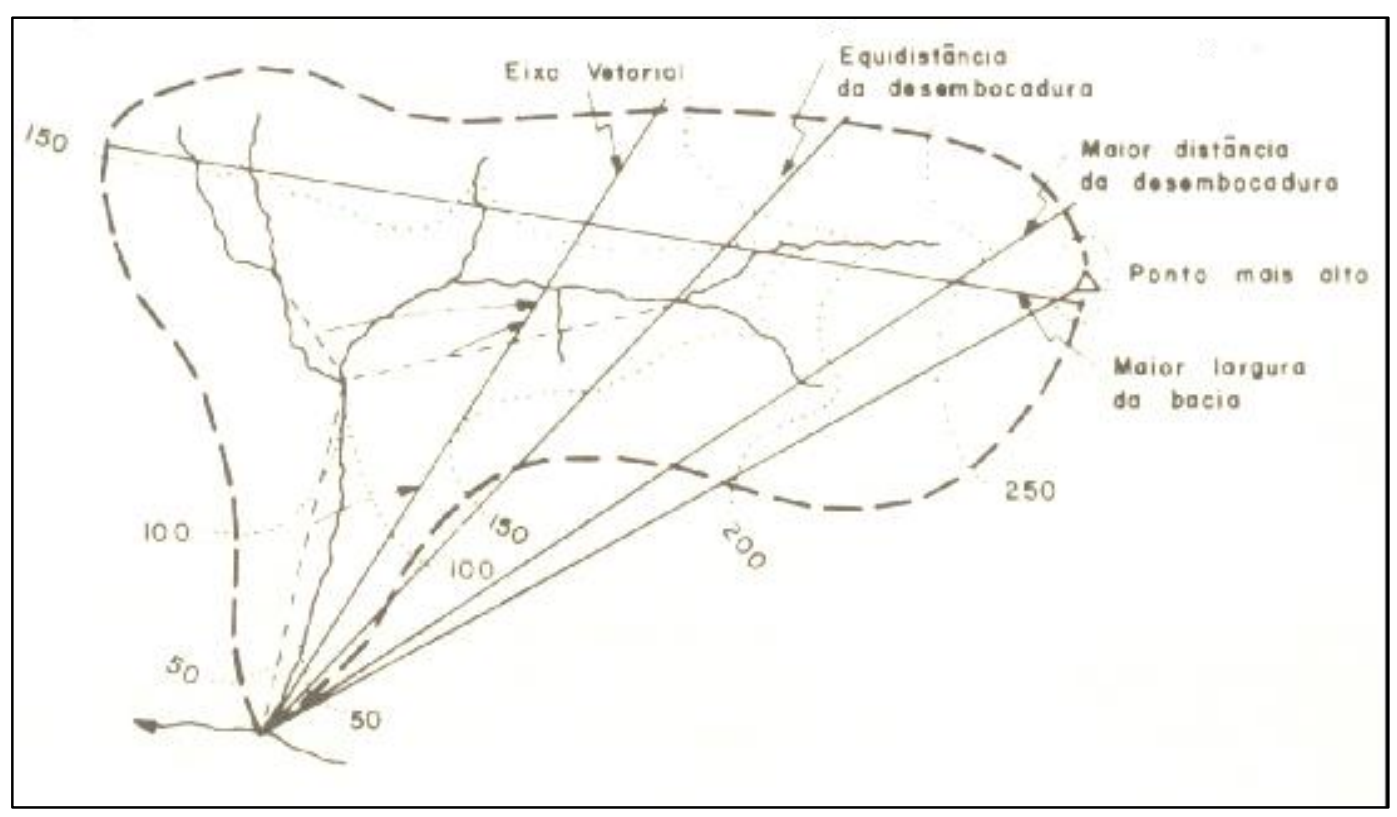

Figura 3: Comprimento da bacia. Fonte: Christofoletti (1980). 
Sua importância se dá por interferir no comportamento hidrológico de algumas variáveis morfológicas, como por exemplo: comprimento de rampas, circularidade e largura das bacias, possibilidade de formação de canais mais longos, entre outras.

\subsection{4 - Hierarquização da Rede de Drenagem}

Os cursos d'água podem ser classificados a partir de uma hierarquia ordenada de seus respectivos trechos. Os critérios de ordenação dos cursos de água na totalidade de uma bacia foram, inicialmente, propostos por Horton (1945) e modificados por Strahler (1952) e, a ordem dos cursos d'água representa o grau de ramificação do sistema de drenagem da bacia (CHRISTOFOLETTI, 1980; TUCCI, 2002; FLORENZANO, 2008).

A modificação realizada por Strahler (1957) referiu-se apenas as interconexões, formas ou orientação das ligações fluviais. No caso Strahler explica que, os canais menores são considerados como de primeira ordem, estendendo-se desde a nascente até a confluência, dois rios de primeira ordem já bastam para que seja formado um rio de segunda ordem, a confluência de dois rios de segunda ordem define um de terceira e assim sucessivamente.

Esta classificação e ordenação da drenagem implicam na capacidade de produção hídrica das bacias hidrográficas, ou seja, bacias que apresentam maior quantidade de rios de primeira ordem classificam-se como bacias com menor capacidade de produção hídrica, enquanto que bacias com maior quantidade de rios com ordens superiores tendem a apresentar maior capacidade hídrica, permitindo inferir a perenidade ou intermitência do canal e o maior fluxo de sedimentos em suspensão (JUNIOR e ANDREOLI, 2014).

Tonello (2006) disserta em seu trabalho que ordem de drenagem inferior ou igual a 4 é comum em pequenas bacias hidrográficas e reflete os efeitos diretos do uso da terra; considera-se que, quanto mais ramificada for a rede, mais eficiente será o sistema de drenagem.

Ademais, por meio da análise da classificação realizada por Strahler, pode-se inferir o nível de erosão dentro de uma bacia, bem como o grau de transporte de sedimentos e ação fluvial no relevo (FERREIRA, 2013), pois bacias de ordem superior são mais desenvolvidas, propiciando maior capacidade de transporte de materiais. 


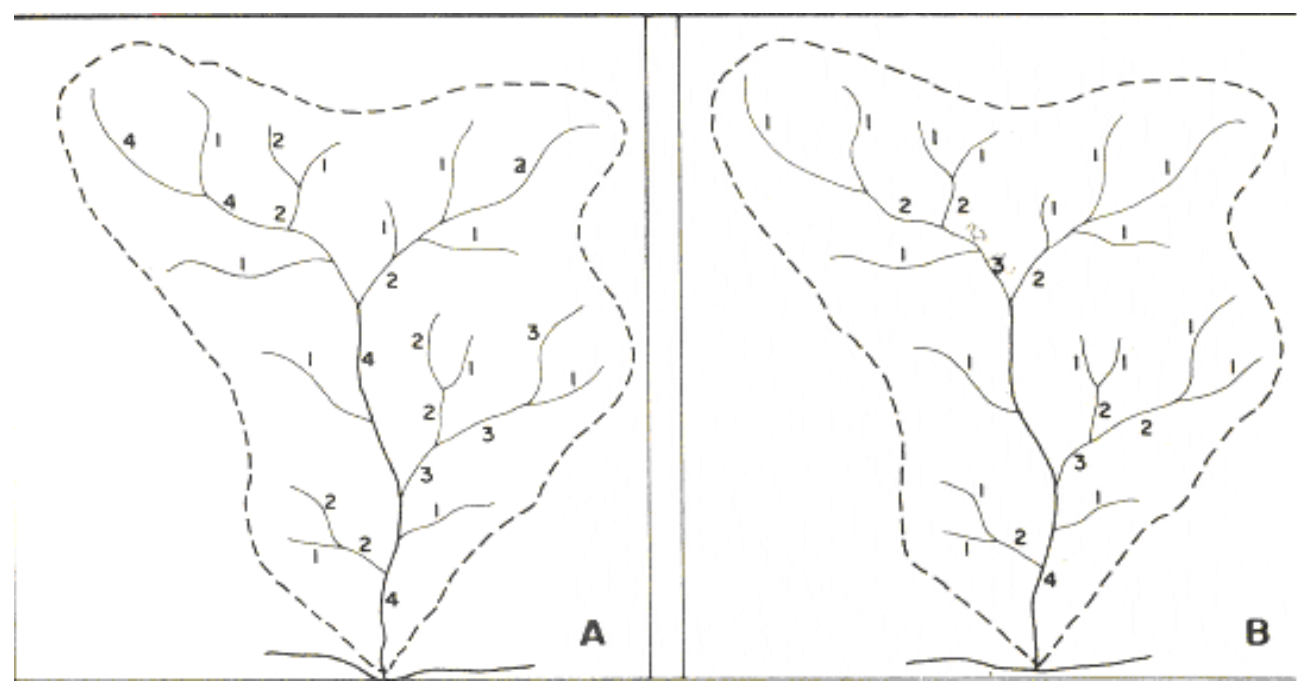

Figura 4: Hierarquização segundo Horton (A) e Strahler (B). Fonte: Christofoletti, 1980.

Segundo Villela e Mattos (1975), o índice de hierarquização da rede de drenagem pode variar de $0,5 \mathrm{~km} / \mathrm{km}^{2}$ em bacias com drenagem pobre, de 3,5 ou mais nas bacias excepcionalmente bem drenadas. Valores baixos de densidade de drenagem estão geralmente associados a regiões de rochas permeáveis e de regime pluviométrico caracterizado por chuvas de baixa intensidade ou pouca concentração da precipitação (VILLELA e MATTOS, op.cit e TONELLO, 2006).

\subsection{5 - Densidade de Drenagem}

Inicialmente este índice foi proposto por Horton (1945) e posteriormente Christofoletti (1980), trouxe as exposições realizadas por Horton, onde explica que a densidade de drenagem compreende o comprimento médio dos rios de uma bacia hidrográfica por unidade de área, dado pela seguinte equação:

$$
D_{d}=\frac{C d}{A}
$$

Onde:

$\boldsymbol{D} \boldsymbol{d}=$ Densidade de drenagem $(\mathrm{m} / \mathrm{ha}) ;$

$\boldsymbol{C} \boldsymbol{d}=$ Comprimento total de canais de drenagem $(\mathrm{m})$

$\boldsymbol{A}=$ Área total (ha).

Este índice pode ser aplicado como um indicador do nível de desenvolvimento de uma bacia hidrográfica, permitindo inferir sua eficiência de drenagem, relacionando-a com o tempo 
gasto para o escoamento superficial deixar a bacia hidrográfica (LIMA, 2008). Lima (op.cit) vem estabelecer padrões de índices de densidade de drenagem e, em seu estudo separa os índices de densidade de drenagem em baixa, média, alta e muito alta (Tabela 1):

Tabela 1: Valores de densidade de drenagem. Fonte: Lima, 2008.

\begin{tabular}{|c|c|}
\hline Valores de Dd $\left(\mathrm{km} / \mathrm{km}^{2}\right)$ & Qualificação de Dd \\
\hline Menor que 5,0 & $\begin{array}{l}\text { Baixa densidade da drenagem } \\
\text { - tendem à perenidade. }\end{array}$ \\
\hline De 5,0 a 13,5 & $\begin{array}{l}\text { Média densidade da drenagem } \\
\text { - tendem a apresentar regime } \\
\text { de fluxo perene ou } \\
\text { intermitente. }\end{array}$ \\
\hline De 13,5 a 155,5 & $\begin{array}{l}\text { Alta densidade da drenagem - } \\
\text { os novos canais formados } \\
\text { tendem a ser efêmeros. }\end{array}$ \\
\hline Maior que 155,5 & $\begin{array}{l}\text { Muito alta densidade da } \\
\text { drenagem - tendem à } \\
\text { formação de canais efêmeros. }\end{array}$ \\
\hline
\end{tabular}

A densidade de drenagem está estreitamente associada as características pedológicas da região que a integra, pois, quanto maior o índice menor é a capacidade de infiltrar água, valores baixos indicam que a região é mais favorável a infiltração contribuindo com o lençol freático (CASTRO e CARVALHO, 2009). Christofoletti (1981), Castro e Carvalho (2009) trazem que quanto maior o índice a densidade de drenagem na bacia maior a capacidade de erosão fluvial, ou seja, locais com índice de drenagem alta apresentam uma superfície com maiores índices de dissecação, eficiência em transportar sedimentos e maiores vazões em seu curso principal, consequentemente devido ao solo ser mais susceptível à erosão a quantidade sedimentar transportada para os rios é maior que em bacias menos dissecadas.

Para um mesmo tipo de clima, a densidade de drenagem depende do comportamento hidrológico das rochas. As rochas mais impermeáveis possuem melhores condições para o escoamento superficial, apresentando mais rapidez nas respostas hídricas, possibilitando a formação de canais e, consequentemente, aumentando a densidade de drenagem (LINSLEY, 1975; CASTRO e CARVALHO, 2009). 


\subsection{6 - Densidade de Rios}

Relacionada com a quantidade de canais existente em uma bacia está o índice de densidade de rios, este é estabelecido pela relação entre o número total de canais ou rios e a área da bacia hidrográfica em que se inserem, sendo representada pela seguinte equação (CHRISTOFOLETTI, 1980):

$$
D_{r}=\frac{N}{A}
$$

Onde:

Dr - Densidade de rios;

$N$ - Número total de canais na bacia considerada;

$\boldsymbol{A}$ - Área da bacia considerada;

Conforme Junior e Andreoli (2014) esta equação permite comparar a frequência ou a quantidade de canais existentes em uma área de tamanho padrão, a qual possibilita demonstrar sua magnitude. Com o resultado deste índice é possível inferir se as bacias apresentam solos pouco permeáveis e/ou maior propensão a escoamento superficial, uma vez que solos que apresentam maior tendência ao escoamento, ou seja, menor predisposição à infiltração são mais dissecados, podendo originar rios.

Desta forma, bacias que apresentam índices elevados de densidade de rios são bacias que apresentam solos com maior capacidade de escoamento superficial e capacidade de gerar novos rios, entretanto nem todas as bacias hidrográficas exibem boas condições de manutenção destes rios.

\subsection{7 - Coeficiente de Manutenção da Bacia}

A manutenção de bacias hidrográficas se dá pela capacidade que esta apresenta de manter 1metro de canal de forma equilibrada, ou seja, este índice exprime a área mínima para a manutenção de 1metro de canal de escoamento (CRISTOFOLETTI, 1980); podendo ser expresso pela seguinte expressão, ademais, esta foi definida a fim de que seja significante na escala métrica: 


$$
C_{m}=\left(\frac{1}{D_{d}}\right) \times 1.000
$$

Onde:

$\boldsymbol{C m}$ - Coeficiente de manutenção;

$\boldsymbol{D} \boldsymbol{d}$ - Densidade da Drenagem.

Este coeficiente expressa que quanto maior for a área necessária para a manutenção de um canal de drenagem maior será sua probabilidade de apresentar regime de fluxo perene, visto que à montante haverá maior superfície de infiltração se comparada a canais com um menor coeficiente de manutenção.

É relevante destacar que os valores médios da extensão do escoamento superficial e do coeficiente de manutenção, ao contrário das demais características, diminuem à medida que o relevo se torna mais movimentado, pois terrenos muito dissecados com alta densidade de rios faz com que a extensão do percurso superficial seja reduzida condicionando menores áreas de contribuição ou manutenção (CHRISTOFOLETTI, 1980; PISSARA et. al., 2004; JUNIOR e ANDREOLI, 2014).

\subsection{8 - Extensão do Escoamento Superficial}

A extensão do percurso superficial é a distância média percorrida pelas enxurradas entre o interflúvio e o canal permanente, corresponde a uma das variáveis mais importantes que afeta tanto o desenvolvimento hidrológico quanto a fisiografia das bacias de drenagem, tal parâmetro é aproximadamente igual a metade do valor do índice de densidade de drenagem, sendo expresso pela seguinte equação:

$$
E p s=\frac{1}{2 \times D_{d}}
$$

Onde:

Eps - Extensão do percurso superficial

$\boldsymbol{D} \boldsymbol{d}$ - Densidade da Drenagem 
Este índice morfométrico é relacionado a diversas variáveis ambientais, não apenas no sentido de afetá-las, mas também no sentido de exercer controle. Dentre estas variáveis podemse citar as características pedológicas da bacia, o tipo de vegetação, declividade do terreno, dentre outras variantes.

Entre estas variáveis, as características do solo e a declividade do terreno são as que mais influenciam na extensão do escoamento superficial, pois relevos menos dissecados e com rampas maiores tendem a apresentar maiores extensões de escoamento (TONELLO, 2006; TEODORO, 2007).

Este índice, devido suas variáveis controle, influencia diretamente os processos erosivos e a produção de sedimentos da bacia, tal como Junior e Andreoli (2014) afirmam que extensões muito longas favorecem o desenvolvimento de processos erosivos, visto que o escoamento atinge maior velocidade em vertentes longas, implicando num alongamento da incisão ou ainda no aumento de canais efêmeros, já nas bacias com curtas extensões de escoamento superficial pode ocorrer maior número de enchentes.

\subsection{9 - Índice de Circularidade}

Identificar a forma superficial de uma bacia hidrográfica é importante para determinação do tempo de concentração hídrica, ou seja, o tempo necessário para que toda a bacia contribua para a saída da água após uma precipitação, desta forma, quanto maior o tempo de concentração, menor a vazão máxima de enchente, se mantidas constantes as outras características (VILLELA e MATTOS, 1975; CHRISTOFOLETTI, 1980; TONELLO, 2006; JUNIOR e ANDREOLI, 2014).

Assim, o índice de circularidade de uma bacia é aplicado para determinar sua forma, o processo de alargamento da bacia e a suscetibilidade desta à ocorrência de enchentes, em que o valor máximo obtido é igual à 1,0, e quanto mais próxima a este valor mais parecida com um círculo é a bacia, logo quanto mais distante da unidade mais alongada é esta bacia (CHRISTOFOLETTI, 1980). A expressão utilizada para se chegar a este índice é a seguinte:

$$
I_{c}=\frac{A}{A_{c}}
$$


Onde:

Ic - Índice de circularidade;

$\boldsymbol{A}$ - Área da bacia considerada;

$A \boldsymbol{c}$ - Área do círculo com perímetro igual ao da bacia considerada.

Os resultados deste índice evidenciarão, caso a bacia apresente forma circular, um escoamento mais lento, possivelmente menor taxa de sedimentação, maior probabilidade de enchentes; entretanto, bacias com formas mais alongadas exibem escoamento mais rápido, maiores taxas de sedimentação e dissecação do relevo, baixa propensão a inundações e formas menos onduladas do relevo (ANTONELI e THOMAZ, 2007).

\subsubsection{0 - Coeficiente de Sinuosidade}

A sinuosidade (SIN) de uma bacia hidrográfica representa a relação entre o comprimento do rio principal e o comprimento do seu talvegue, atuando como um fator controlador da velocidade de escoamento superficial (NUNES et.al, 2006).

Para a determinação deste coeficiente devem-se definir dois pontos, um a montante e outro a jusante, medindo-se a distância direta entre eles e calculando-se em seguida a distância total do canal de drenagem, considerando seus meandros (CHRISTOFOLETTI, 1980; ANTONELI e THOMAZ, 2007).

Interligando este índice com a descarga sólida tem-se que descargas com predomínio de material mais grosso tendem a moldar canais mais largos e rasos, com baixo índice de sinuosidade (SIN), enquanto aqueles com descarga sólida mais finas e leves predominam em canais mais estreitos e profundos, com elevado índice de sinuosidade (SIN) (CHRISTOFOLETTI, op.cit; ANTONELI e THOMAZ, op.cit).

A North Carolina Division of Water Quality (2005) apud Junior e Andreoli (2014) propõem quatro classificações relacionadas a sinuosidade (SIN) de um canal: 
Tabela 2: Classificação da sinuosidade da bacia hidrográfica. Fonte: NC Division of Water Quality, 2005.

\begin{tabular}{cc}
\hline Relação de Sinuosidade & Qualificação \\
\hline Superior a 1,4 & Forte - canais apresentam \\
inúmeras curvas e poucos trechos & retilíneos, tendendo a ser perenes. \\
Mntre 1,2 e 1,4 & Moderada - os canais apresentam \\
& sinuosidade, mas também alguns \\
& segmentos retilíneos. A tendência \\
& é apresentar perenidade ou \\
intermitência.
\end{tabular}

Em sua obra Geomorfologia Christofoletti (1980) ressalta que canais que apresentam índices de sinuosidade superior ou igual a 1,5 são considerados meândricos, o que confere com a tabela de sinuosidade citada acima, onde está esclarecido que localidade com índices superiores a 1,5 apresentam inúmeras curvas e poucos trechos retilíneos.

\subsubsection{1- Escoamento Superficial}

Influenciado pelos índices morfométricos (declividade do terreno, rugosidade, dentre outros), pelas características pedológicas da área da bacia, pelo comportamento hidrológico atuante no local e pela vegetação tem-se a atuação do escoamento superficial, que para este estudo é bastante válida sua compreensão. 
Desta forma, pode-se afirmar que o escoamento superficial é impulsionado por duas variáveis: a gravidade e declividade; a gravidade age impulsionando os filetes d'água para as cotas mais baixas, ocasionando uma rede de drenagem efêmera que converge para a rede de curso de água mais estáveis (arroios, rios, oceanos), já a declividade auxilia na aceleração, onde relevos mais íngremes possibilitam maior velocidade de escoamento. (WISLER \& BRATER, 1964; COELHO NETTO, 1994; SILVEIRA, 2009; CHRISTOPHERSON, 2012).

Isto posto, tem-se que o escoamento acontece quando a taxa de chuva excede a capacidade de infiltração na superfície do solo, ou seja, à medida que a umidade na camada superficial do perfil do solo aumenta, mais próxima da saturação o meio está, quando este é atingido ocorre o extravasamento (DUNNE, 1943; LIMA, 2007; SILVA, 2012).

Em áreas tropicais chuvosas o comportamento dos fluxos de água no solo segue o modelo de Hewlett \& Hilbert, estes autores argumentam que parcela d'água infiltrada retornaria a superfície via saturação do solo formando canais efêmeros antes de chegar ao canal principal, neste modelo considera-se a topografia na localização das bacias e a dinâmica das áreas saturadas, indicando o seu tamanho variável conforme a intensidade do evento e as condições iniciais de umidade no solo (SIEFERT E SANTOS, 2012).

Assim, há os efeitos provocados no solo pela chuva, os quais irão variar conforme a intensidade pluviométrica, como por exemplo, os efeitos originados por uma chuva forte são bem diferentes dos efeitos causados por uma chuva com a mesma quantidade de água, porém com duração mais prolongada. Chuvas mais fracas e prolongadas intensificam a infiltração da água, alimentando o lençol subterrâneo (SIMÕES e COIADO, 2001).

Ao direcionar esta temática à produção de sedimentos tem-se que boa parte das partículas de solo removidas pelo salpicamento escoará junto com o fluxo superficial até atingir o curso d'água compondo os sedimentos em suspensão.

\section{2 - Ciclo Hidrológico}

Tratado detalhadamente dentro da ciência Hidrologia, o ciclo hidrológico é visto como um fenômeno global de circulação fechada da água entre a superfície terrestre e a atmosfera fundamentalmente pela energia solar associada à gravidade e a rotação terrestre (Tucci, 2013). Ainda conforme Tucci (op.cit) o intercâmbio entre as circulações da superfície terrestre e da atmosfera, fechando o ciclo hidrológico, ocorre em dois sentidos: 
1- No sentido superfície-atmosfera, onde o fluxo de água ocorre fundamentalmente na forma de vapor (evaporação e transpiração);

2- No sentido atmosfera-superfície, onde a transferência de água ocorre em qualquer estado físico, sendo mais significativas, em termos mundiais, as precipitações de chuva e neve.

Consoante a USGS - United States Geological Survey o ciclo hidrológico pode ser sinteticamente descrito, de modo geral, pelas seguintes etapas:

- Energia solar: Fundamental ativador deste ciclo, esta energia somente é aproveitada pelo efeito estufa natural.

- Precipitação: corresponde à quantidade de água resultante da condensação do vapor de água na atmosfera, que se precipita de forma líquida dando origem a chuva, ou de forma sólida originando neste caso neve ou granizo que se deposita na superfície terrestre. Intervém no ciclo hidrológico onde exerce um papel chave e indispensável.

- Interceptação: Caindo a água da chuva sobre o solo com cobertura vegetal, esta funciona como uma barreira interceptadora da precipitação. Excedendo a capacidade de armazenar água na superfície dos vegetais a água pode reprecipitar para o solo.

- Infiltração: A água que atinge o solo e não é interceptada pela vegetação infiltra até este meio atingir seu ponto de saturação, isso consiste no fluxo de água da superfície que se infiltra no solo, essa água quando acumulada no subsolo forma os lenções freáticos.

- Escoamento Superficial: É impulsionado pela gravidade para as cotas mais baixas. A medida que a água precipitada atinge o solo e é infiltrada, este vai atingindo seu ponto de saturação, ou seja, sua capacidade de armazenamento, desta forma a água, segundo o modelo Hortoniano após preencher as depressões de solos rasos o excedente se transforma em escoamento superficial, provocando erosão de partículas do solo por filetes em seus trajetos, juntamente com a declividade do terreno, assim molda uma micro rede de drenagem efêmera que converge para a rede de drenagem estável. 
- Evaporação: Qualquer corpo que contém água sofrerá evaporação, seja ele vegetação, animais, massas hídricas etc. A evaporação consiste na transformação da água presente na superfície terrestre no seu estado líquido para o estado gasoso à medida que se desloca da superfície para a atmosfera.

- Transpiração: é a forma como a água existente nos organismos passa para a atmosfera, para que ela ocorra é fundamental a existência de um gradiente de pressão do vapor.

- Evapotranspiração: Termo sugerido por Thorntwaite em seus estudos sobre balanço hídrico. Caracteriza-se como processo pela qual a água que cai é absorvida pelas plantas, voltando à atmosfera através da transpiração ou evaporação direta (quando não absorvida), ou seja, é a soma da evaporação e da transpiração, depende da radiação solar, das tensões de vapor do ar e dos ventos.

- Condensação: é uma das fases em que ocorre a transformação da matéria, do estado gasoso para o estado líquido. Neste processo as moléculas de água liberam energia, denominada de calor latente de condensação, equivalente àquela absorvida durante a evaporação. Esta energia é imprescindível na produção de fenômenos violentos de tempo e pode ser responsável pela transferência de grandes quantidades de calor dos oceanos tropicais para posições mais próximas aos polos.

A (Figura 05) representa a exposição citada acima. 


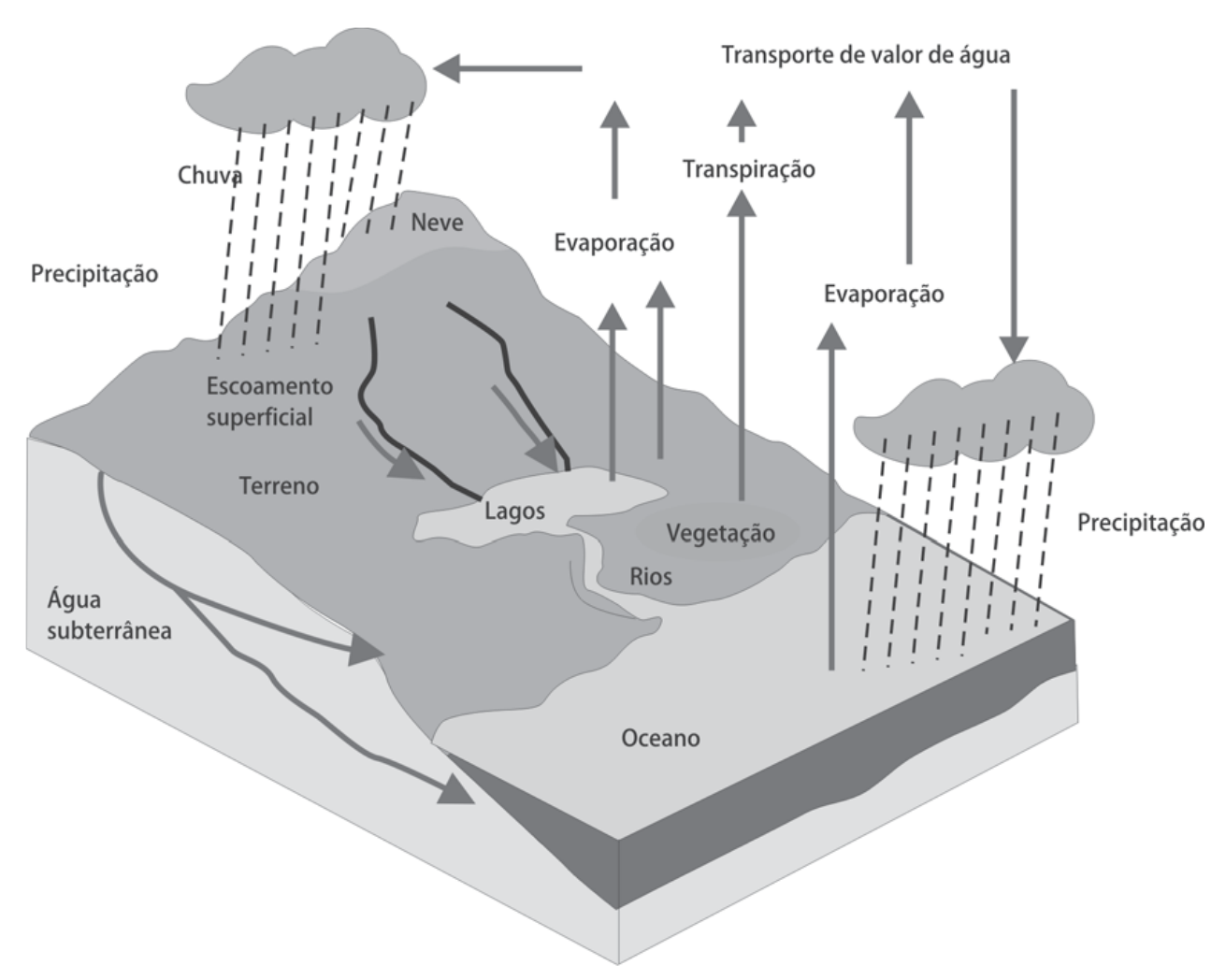

Figura 5: Ciclo hidrológico. Fonte: Tucci e Mendes (2006).

\section{3- Bacia Hidrográfica}

Bacia hidrográfica é uma superfície terrestre de captação, drenada por um canal principal e seus tributários carreando certa quantidade de material de origem natural e antrópica, transformando precipitação em fluxo de água que escoará para sua foz, tal como córregos, rios ou oceanos (BROOKS, 1991; MOURA et al., 2009; TUCCI, 2013).

Uma bacia hidrográfica compõe-se basicamente de um conjunto de superfícies vertentes e de uma rede de drenagem formada por cursos de água que confluem até resultar um leito único no exutório (TUCCI, 2013). Ainda de acordo com Tucci (op.cit) as vertentes funcionam como fonte produtora de sedimentos e a rede de drenagem como transportadora destes; as vertentes produzem os sedimentos por fenômeno de erosão e estes são transportados com a água pela rede de drenagem.

Desta forma uma bacia hidrográfica pode ser compreendida como unidade hidrogeomorfológica de um clássico sistema aberto, pois recebe inputs energéticos das forças atuantes na área (climáticos, tectônicas subjacentes e antrópicos) e, perde energia por meio da água, sedimentos e materiais dissolvidos despejados por uma saída comum (HACK (1960); CHORLEY et. al, (1962), CHRISTOFOLETTI (1980), GUERRA e CUNHA (1994); LEOPOLD et al. (1995); FLORENZANO (org.) (2008). 
As variáveis básicas que mantém o sistema bacia hidrográfica e os caracterizam são: precipitação (P), evapotranspiração (ET), deflúvio (D) e variação do armazenamento (superficial e/ou subterrâneo) $(\Delta \mathbf{S})$, o que caracteriza a equação do balanço hídrico (SANTOS et al. 2001):

$$
\boldsymbol{P}-\boldsymbol{E T}=\boldsymbol{D}+\Delta \boldsymbol{S}
$$

- Precipitação: É tida como qualquer tipo de fenômeno relacionado à queda de água da atmosfera terrestre, isso pode ser na forma de neve, chuva e de granizo, a precipitação é um importante suprimento de umidade para a superfície da Terra, ademais de ser o principal fator de controle hidrológico de uma região (DUNNE, 1943); CHRISTOPHERSON, 2012), variando principalmente de acordo com a latitude e configurações do relevo local (TUCCI, 2013).

- Evapotranspiração: Esta variável é caracterizada pela junção da evaporação e da transpiração resultando no fenômeno da evapotranspiração (TUCCI, 2013).O processo da evapotranspiração se dá movimento de moléculas de água livres, que se afasta de uma superfície úmida até a atmosfera menos saturada e a transpiração é a ação realizada pelos seres vivos (vegetal e animal) para se resfriarem, estão intimamente relacionados com a umidade relativa do ar e a temperatura do meio; (CHRISTOPHERSON op. cit.).

- Deflúvio: É o escoamento superficial ou run-off, processo pelo qual a água da chuva precipita na superfície da Terra, flui por ação da gravidade, das partes topográficas mais altas para as mais baixas, no leito dos corpos hídricos (LEOPOLD et. al. 1992; DUNNE, 1943). Conforme Santos et al. (2001), o deflúvio é comumente substituído pela vazão, sendo o quantitativo escoado na unidade de tempo $\left(\mathrm{m}^{3} / \mathrm{s}\right)$.

- Variação do Armazenamento: A capacidade de armazenamento está intimamente relacionada com a capacidade de infiltração, como sendo a taxa máxima com que um dado solo, em determinadas condições, pode adsorver água (HORTON, 1933, CRISTOPHERSON, op. cit.). Já a variação do armazenamento dependerá das condições do ambiente, tais como temperatura, umidade, profundidade do solo e o material do qual o solo é formado, entretanto todo solo possui capacidade máxima de armazenamento, quando esta capacidade é atingida ocorre o escoamento superficial ou, em alguns, casos drenagem profunda. 
Bacias hidrográficas podem comportar diferentes usos em seus limites, sendo utilizadas para captação d'água, para saneamento básico, para experimentos, como área de proteção ambiental, irrigação, dentre outros usos possíveis para esta feição.

\section{4 - Pesquisas sistemáticas em bacias hidrográficas}

Uma bacia hidrográfica pode ser classificada segundo as atividades desenvolvidas nela, podendo classificar-se como uma bacia representativa, bacia benchmark e como uma bacia experimental.

Uma bacia representativa funciona como um pequeno laboratório, no qual se estabelece um meio comparativo entre o espaço utilizado para aplicação dos processos pesquisados e o mundo real, o que possibilita a compreensão das relações e processos envolvidos no ciclo hidrológico que determinam a ocorrência espaço-temporal dos recursos hídricos (SRAJ et al., 2008; MEDEIROS et al., 2005 in PIMENTEL DA SILVA et al (2010); de acordo com Toebes,; Robinson e Whitehead (1992) as interferências ocorridas neste tipo classificatório de bacia durante o experimento devem ser as mínimas possíveis.

Já as bacias experimentais devem estar aninhadas umas dentro das outras em variados tamanhos para possibilitar o estudo dos processos hidrológicos em diversas escalas (VILLASBOAS et. al., 2011). Essas bacias seriam para aplicar os experimentos desejáveis capazes de transformar as feições, não considerando os impactos causados. Conforme Fragoso (2008) este tipo de bacia define-se ainda como sendo aquela onde solo e a vegetação são relativamente homogêneos e as características físicas são uniformes.

Segundo Villas-Boas et. al. (2011), atualmente, há uma tendência, tanto brasileira como mundial, em desenvolver estudos em bacias experimentais e representativas de forma a caracterizar a disponibilidade hídrica de bacias de diferentes tamanhos, características de uso e ocupação do solo a fim de compreender a variação dos recursos hídricos no tempo e no espaço.

Por último tem-se a classe das bacias tipo benchmark, que conforme Mast e Tark (1999), os trabalhos neste tipo de bacia iniciaram na década de 1960 com Luna Leopold a fim de adquirir um longo período de mensuração em canais e de qualidade d'água em áreas onde há pouca interferência humana. Desta forma uma bacia do tipo benchmark designa-se por ser utilizada para que se obtenha a tendência temporal das características hidrológicas entre as respostas de uma bacia em conservação e outra com as alterações realizadas durante os experimentos. 


\section{5 - Hidrossedimentologia}

Bacias hidrográficas diferenciam-se conforme seu uso principal, entretanto todas, independentemente de sua classificação, estão relacionadas ao controle do ciclo hidrológico, que se associa com a produção de sedimentos, o equilíbrio destes predispõe a perpetuação da bacia como forma de uso viável à utilização. O ciclo hidrológico por ser um processo dinâmico é responsável pelos diferentes caminhos que a água pode percorrer e se transformar ao longo do tempo carreando sedimentos por onde passa (CARVALHO, 2014).

Devido ao processo de transformação dos recursos hídricos e suas consequências para o meio ambiente surgiu a necessidade de estudar os processos hidrossedimentológicos, caracterizando o estudo da erosão hídrica, dos sedimentos fluviais e dos depósitos em rios e reservatórios (CARVALHO, 1994). Conforme Mendonça (2013) os processos responsáveis pela sedimentação são muito complexos, abrangem desde a erosão, deslocamento até os rios, transporte dos sedimentos nos cursos d'água, deposição do sedimento e sua compactação.

Entretanto os processos sedimentares não são fatores isolados no ambiente, se correlacionam com as problemáticas ambientais, tal como degradação dos recursos hídricos, prejuízo a fauna e flora aquática, contaminação da rede de drenagem, encarecimento da captação hídrica, dentre outros fatores (ANTONIAZI, 2008).

A fim de se conhecer o quantitativo da carga sedimentar e inferir se está nos limites de gerar esses riscos é necessário realizar medições constantes, in loco, nos corpos hídricos. Segundo Vilela e Matos (1975) e Carvalho (1994) os sedimentos produzidos podem ser mensurados por meio de medições em campo onde se retiram amostras variáveis das seções de controle fluvial e, posteriormente, em laboratório, analisa-se a concentração de sedimentos, podendo ser esta tanto em suspensão quanto da calha dos rios.

O esquema a seguir (Figura 06) demonstra o processo de transporte de sedimento apresentado por Christofoletti (1981). 


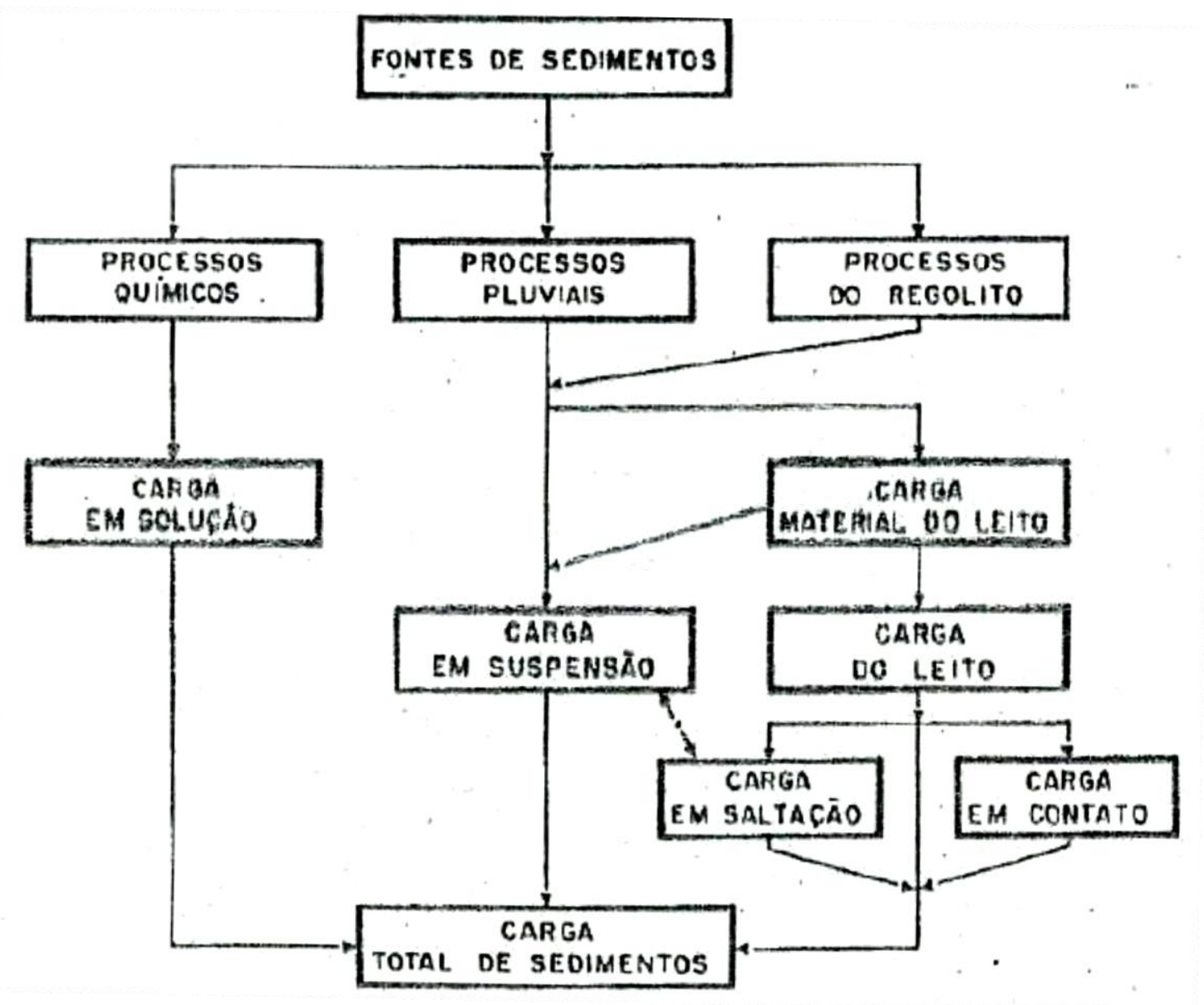

Figura 6: Fluxograma do processo de transporte de sedimento em cursos d'água. Fonte: Christofoletti (1981).

Por meio da (q) se evidencia que até chegar a calha do rio os sedimentos passam por alguns processos, sejam eles químicos (alteração ou dissolução da matéria), pluviais (desagregação da superfície por meio do impacto da chuva), assim como formação do solo (resultante dos processos de intemperismo físico e/ou químico) até tornar-se carga sedimentar dissolvida, em suspensão ou de fundo.

\section{6 - Forças Atuantes nas Partículas de Sedimento Durante o Transporte em Suspenção}

De acordo com Christofoletti (1981) e Carvalho et al. (2000), é entendido que o transporte de sedimentos nos rios é governado por fatores hidrológicos, tal como a chuva, vazão dos rios, vegetação, dentre outros fatores que controlam as características e o regime dos cursos d'água. 
A maior quantidade de sedimento transportado sucede o período chuvoso, é verificado que $70 \%$ a $90 \%$ de todo sedimento transportado pelos cursos d'agua ocorrem neste período, principalmente durante as fortes precipitações (CARVALHO, 1994).

O movimento dos sedimentos nos canais abertos se dá, principalmente, pela atuação de duas forças externas que atuam sobre a água que flui, são elas respectivamente; gravidade e fricção. A gravidade atua verticalmente possibilitando o escoamento das águas e a fricção exercida pelas margens do canal promovem o retardamento do fluxo (CHRISTOFOLETTI (op. cit.), FLORENZANO (org.), 2008; e TUCCI, 2013).

As partículas em suspensão permanecem assim devido a força gravitacional ser rompida pelas forças ascendentes (arrasto e de empuxo), a gravidade faz com que as partículas acelerem rapidamente para o leito até que a força gravitacional se oponha as que resistam ao movimento, causando estado de equilíbrio onde a partícula atinge a velocidade terminal de queda ou velocidade de sedimentação, essas forças são demostradas pela Lei de Stokes e pelo Número de Reynolds (HICKIN, 1995; LIMA e LUZ, 2001).

A Lei de Stokes estabelecida pelo cientista britânico George Stokes em 1851 expressa o tempo de sedimentação de pequenas partículas esféricas em um meio fluido, no caso desta pesquisa o meio fluído é a água. Esta lei aplica-se bem a partículas pequenas e esféricas, pois a medida que o tamanho do grão aumenta a força de inércia também aumenta, fazendo com que a viscosidade se torne insignificante. Segue a equação que expressa a Lei de Stokes:

$$
\vec{F}=-6 \pi r \eta \vec{v}
$$


Onde:

$\vec{F}:$ força de fricção;

$r$ : raio da partícula;

$\eta$ : viscosidade do fluido;

$\vec{v}$ : velocidade da partícula.

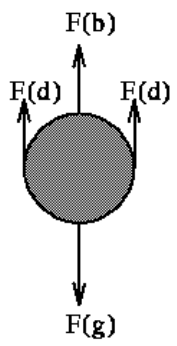

Figura 7: Forças atuantes Lei de Stokes. Onde: Fg: Força Gravitacional; Fb: Força Ascensional; Fd:

Força de Arrasto. Disponível em

$<$ http://www.cee.mtu.edu/ reh/courses/ce251/25

1 notes dir/node4.html $>$.

A Lei de Stokes considera alguns fatores que afetam a velocidade final de deposição das partículas, são elas: diâmetro da partícula; diferença de densidade da partícula e do fluido; viscosidade do fluido; todas as partículas são esféricas e elas não interagem umas com as outras; o fluxo deve ser laminar e apresentar baixo Número de Reynolds $(<500)$, possibilitando carregar apenas finas partículas de silte e argila (RICHARDSON e ZAKI, 1954; HICKIN, 1995).

Ademais, a Lei de Stokes relaciona-se com a força friccional atuante nas partículas que se movem em regime de fluxo laminar com baixos números de Reynolds. O número de Reynolds é um parâmetro adimensional que expressa a razão entre as forças inerciais e as viscosas, ele é dado pela seguinte equação:

$$
R e=\frac{\rho f d v}{\eta}
$$

Onde:

Re: Número de Reynolds;

$\boldsymbol{\rho f}$ : massa específica do fluido [kg.m-3];

d: dimensão linear típica ou diâmetro da partícula [m];

$\mathbf{v}$ : velocidade relativa entre partícula e fluido [m.s-1];

$\boldsymbol{\eta}$ : viscosidade dinâmica [Pa.s=kg.m-1s-2]. 
Quando o Número de Reynolds é (>2000) ocorre o fluxo turbulento dominado pela força da inércia sob as partículas, neste tipo de fluxo ocorre o carreamento de partículas maiores, tais como grão de areia.

Quando a estabilidade entre as leis atuantes sob as partículas cessa, predomina a força gravitacional provocando a sedimentação. A maioria do sedimento em suspensão consiste em grãos finos de areia, argila e silte, conforme a Lei de Stokes cada um destes grãos possuem um tempo de deposição. Segue equação para o cálculo do tempo de deposição:

$$
\mu=\frac{d^{2} g(\rho s-\rho f)}{18 n}
$$

Onde:

$\boldsymbol{\mu}$ : Velocidade de sedimentação das partículas;

$\mathbf{d}^{2}$ : Diâmetro da partícula;

ps: Densidade da partícula;

pf: Densidade do fluido;

n: Viscosidade do fluido.

A seguir apresenta-se a média de tempo que cada um destes tipos de partículas gasta para decantar em 1metro de coluna d'água em um canal em condições normais:

Tabela 3: Velocidade e tempo gasto para decantação de partículas de areia fina, silte e argila. Fonte: Adaptada de Richardson \& Zaki (1954).

\begin{tabular}{|l|c|l|}
\hline Partícula & Velocidade $\left(\mathbf{m} / \mathbf{s}^{-\mathbf{1}}\right)$ & Tempo Gasto \\
\hline Areia Fina & $2.25 \times 10^{-3}$ & 7.4 minutos \\
\hline Silte & $2.25 \times 10^{-5}$ & 12 horas \\
\hline Argila & $2.25 \times 10^{-7}$ & 51 dias \\
\hline
\end{tabular}

(*) considerou-se: temperatura $20 \mathrm{C}$; densidade da água $1000 \mathrm{~kg} \mathrm{~m}-3$; densidade de partículas $2700 \mathrm{~kg} \mathrm{~m}-3$, viscosidade da água 10-3 Pa s.

\section{7 - Regime de Fluxo}

Um canal fluvial é modelado por diferentes fatores morfológicos (largura, profundidade, sinuosidade, declividade, dentre outros) e pelo tipo de descarga líquida (sazonalidade no período de cheia e vazante, classes de sedimento transportado, regime de 
fluxo) (CHRISTOFOLETTI, 1981). Os fluxos podem ser: laminar/turbulento, uniforme/nãouniforme e permanente/não permanente.

As variáveis que implicam no tipo de regime de fluxo e suas alternâncias são: a vazão; largura do canal, declividade do terreno; a viscosidade do fluido; densidade da água e o regime pluviométrico. Desta forma tem-se que o fluxo laminar ocorre quando a água escoa sobre um canal retilíneo e com baixa velocidade fluindo de forma paralela e em camadas; o fluxo turbulento é caracterizado pelas partículas não se moverem ao longo de trajetórias bem definidas, descrevendo trajetórias irregulares, com movimento aleatório, produzindo transferência de quantidade de movimento entre regiões da massa líquida. Este escoamento é comum na água, cuja viscosidade e relativamente baixa (CHRISTOFOLETTI, 1981).

Esses dois tipos de fluxos são diferenciados pelo Número de Reynolds, que para ser determinado considera as características do fluxo e as propriedades do fluído. Christofoletti (1981) estabelece a seguinte correspondência entre o número de Reynolds e os tipos de fluxo: 16 Rey $<500$ fluxo laminar, $500<$ Rey $<2500$ em transição Rey $>2500$ fluxo turbulento.

O fluxo fluvial pode apresentar-se como permanente, quando ocorre em canal fluvial que apresenta velocidade e direção de fluxo constante ao longo do comprimento do canal, conservando a mesma profundidade. Já o não-permanente ocorre quando há variações na velocidade e profundidade ao longo do canal.

Ademais tem-se o fluxo estável, que ocorre quando determinado trecho do canal apresenta uma profundidade constante com o decorrer do tempo, caso não seja constante é denominado de instável.

\section{8 - Transporte de Sedimentos}

Um dos principais fatores que gera/auxilia o transporte de sedimentos é a chuva. Ao atingir o solo promove sua desagregação por meio do salpicamento, ademais, as chuvas (aquelas que totalizam $\pm 60 \mathrm{~mm}$ por evento de chuva) são responsáveis pelas enxurradas que transportam os sedimentos para os cursos d'água, classificando-se assim como o principal agente do transporte sedimentar hídrico (CARVALHO, 1994, INMET).

O material originário do intemperismo físico/químico transportado pelas águas das chuvas, em sua maioria, constitui-se no quantitativo da concentração de sedimentos em suspensão dos cursos de drenagem (CARVALHO, op. cit. e BRANCO, 1998), e o transporte 
deste material pode ser realizado por quatro maneiras distintas: por solução, suspensão, arrasto e saltação (CARVALHO, 1994; GRAF, 1971).

O transporte por solução, conforme explica Summerfield (1991), é aquele em que as substâncias se encontram dissolvidas e concentradas no fluxo, podendo ser mensurada por meio da coleta de amostras e análise química.

O transporte por suspensão é o carregamento do material através do fluxo. A capacidade de carregamento está diretamente relacionada com a velocidade do fluxo existente para o canal, em baixa velocidade há somente o transporte de silte e argila, todavia se o fluxo é turbulento há transporte de partículas grandes, entretanto estas ficarão suspensas apenas enquanto durar a turbulência (CHORLEY, et.al., 1962; SUMMERFIELD, 1991).

É importante ressaltar que a carga sedimentar em suspensão, principalmente em pequenos rios, é maior que a taxa da carga sedimentar de fundo, pois a maioria dos transportes ocorre na forma de suspensão, uma vez que estas partículas possuem peso e tamanho menor, já a carga sedimentar de fundo, necessita de muito mais força do sistema hídrico para arrastá-la (CHEVALLIER, 1993; EDWARD e GLYSSON, 1999; CARVALHO et. al., 2000).

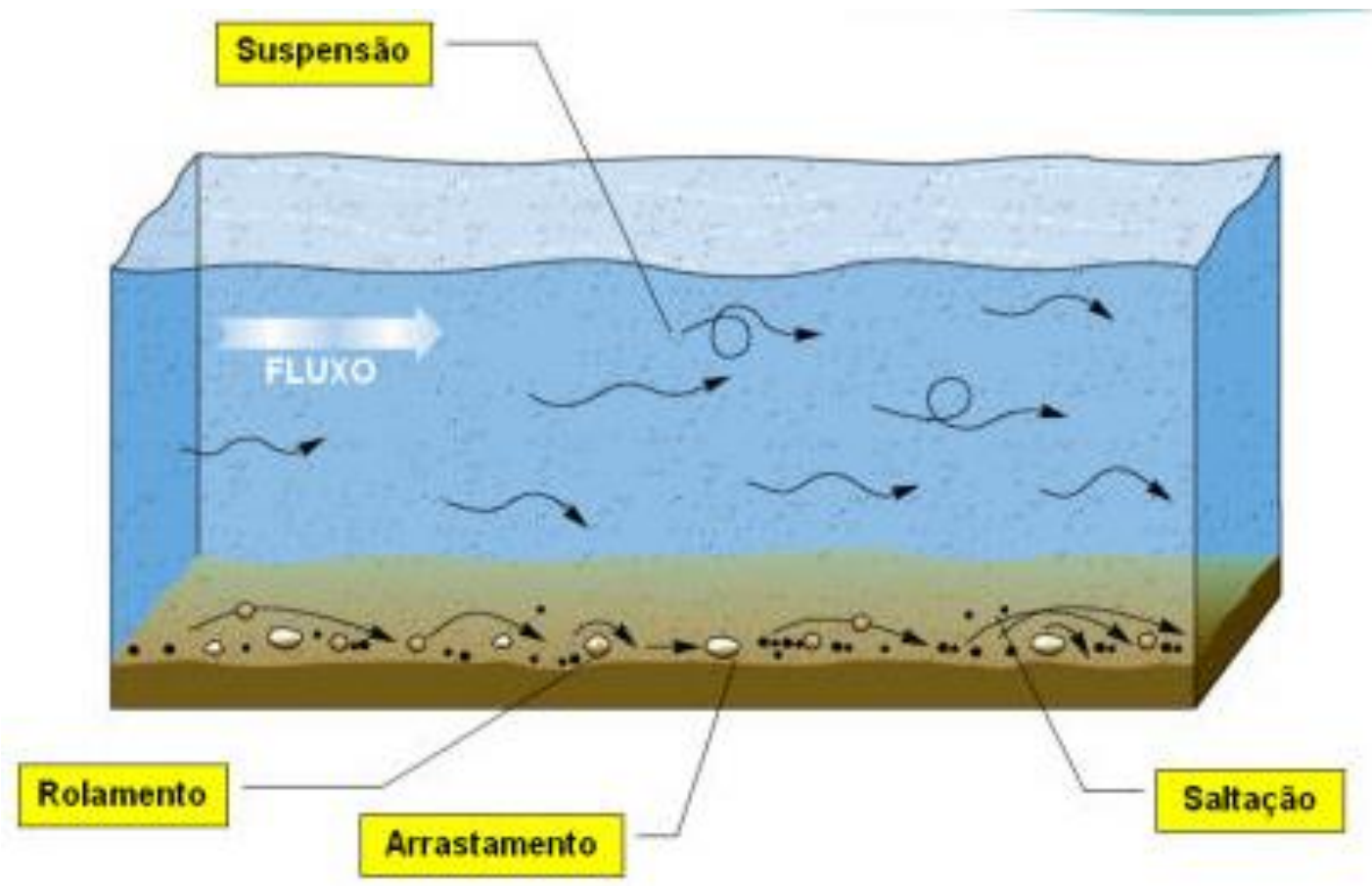

Figura 8: Tipos de Transporte de Sedimentos. Fonte: Disponível em: <http://sed.com.sapo.pt/>.

Desta forma, compreende-se que o transporte por arrasto é mais lento que o transporte da saltação pelo fato das partículas de fundo serem mais pesadas e de rolar pelo leito do rio (CHORLEY, et.al.(op. cit); SUMMERFIELD, op. cit.), entretanto, o processo de transporte de 
leito é o que melhor representa os fatores geomorfológicos em riachos, pois apresentam sedimentos grosseiros e bem ordenados, embora seu quantitativo seja inferior à carga sedimentar em suspensão (LENZI et. al, 2005).

Em relação ao tipo de carga sedimentar, tem-se: a carga em suspensão e a carga de leito (fundo) de rios; a distinção entre elas baseia-se mais no mecanismo de transporte do que no tamanho das partículas. Em geral a carga em suspensão é a fração mais fina do material do leito, sendo mantida suspensa pela ação de turbulência do fluído e a carga de leito é aquela mais pesada, de maior granulometria e tamanho (CHRISTOFOLETTI, 1981.).

Assim, concebe-se que o fluxo turbulento dos rios é uma variável importante para o carregamento destas partículas, pois havendo fluxo mais lento, a capacidade de transporte diminui, implicando na deposição das partículas mais pesadas. Isto justifica a necessidade de se medir a vazão e a carga sedimentar em vários postos, uma vez que elas variam ao longo do canal, variando ainda de acordo com a profundidade deste e a distância entre o centro da secção até a margem.

\section{9 - Métodos de Amostragem}

A finalidade da amostragem é definir a tipologia e a concentração do material transportado no momento da medição, de forma a se obter amostras representativas na seção transversal do curso d'água (SANTOS et al., 2001).

Cada pesquisa definirá o método que melhor se ajuste, pois varia de acordo com o objetivo da pesquisa. Entretanto os mais utilizados são o do tipo integrador na vertical e os métodos pontuais (POLETO e MERTEN, 2006).

Segundo o Manual de Amostragem da ANA (2011) os métodos ou técnicas de amostragem de material em suspensão são: pontual instantâneo, pontual por integração e integração nas verticais, observando os limites de cada medição.

Ainda de acordo com o manual da ANA (op.cit), a amostragem mais rotineira é por integração na vertical, pois permite a obtenção da concentração e da granulometria média na vertical. A amostragem é realizada em várias verticais a fim de permitir a obtenção de valores médios em toda a seção fluviométrica, sendo a distribuição de sedimento variável em toda a largura e profundidade do rio (CARVALHO, 1994).

Diversos autores, dentre eles Carvalho (op.cit.), ANEEL (2000), Poleto e Merten (2006) afirmam que existem, basicamente, duas técnicas de amostragem eficientes e utilizadas 
para monitoramento de sedimentos em rios: a denominada Igual-Incremento-Largura (IIL) e a chamada Igual Incremento de Descarga (IID).

O método de Igual Incremento de Descarga - IID exige o conhecimento prévio da distribuição da velocidade na vertical e da vazão na seção transversal, sendo esta última dividida em subseções onde há a mesma porção de vazão. Em cada seção individual, uma velocidade de trânsito é determinada para estabelecer um volume de amostra para a vertical, que seja igual aos volumes individuais de cada uma das verticais, resultando em representação da vazão total através da zona amostrada. Este método, assim como o do IIL são bastante eficientes, todavia o IID é mais adequado para rios de maior porte, pois concentra maior volume de amostras (CARVALHO, 1994).

Nesta pesquisa foi aplicado o método do IIL, pois os rios amostrados são de pequeno a médio porte. Para o IIL é exigida a divisão da seção transversal em uma série de segmentos de igual largura, para obter-se uma série de subamostras, sendo a velocidade de trânsito igual em todas as verticais, entretanto os volumes amostrados serão diferentes. O volume amostrado é proporcional à quantidade de fluxo em cada uma das várias verticais, para isso, antes de se coletar os sedimentos é necessário identificar a vazão do rio. Ao final da amostragem será obtido um volume de amostragem bruta proporcional à vazão total (EDWARDS e GLYSSON, 1999; CARVALHO, 1994, SANTOS et al., 2001, BICALHO, 2006).

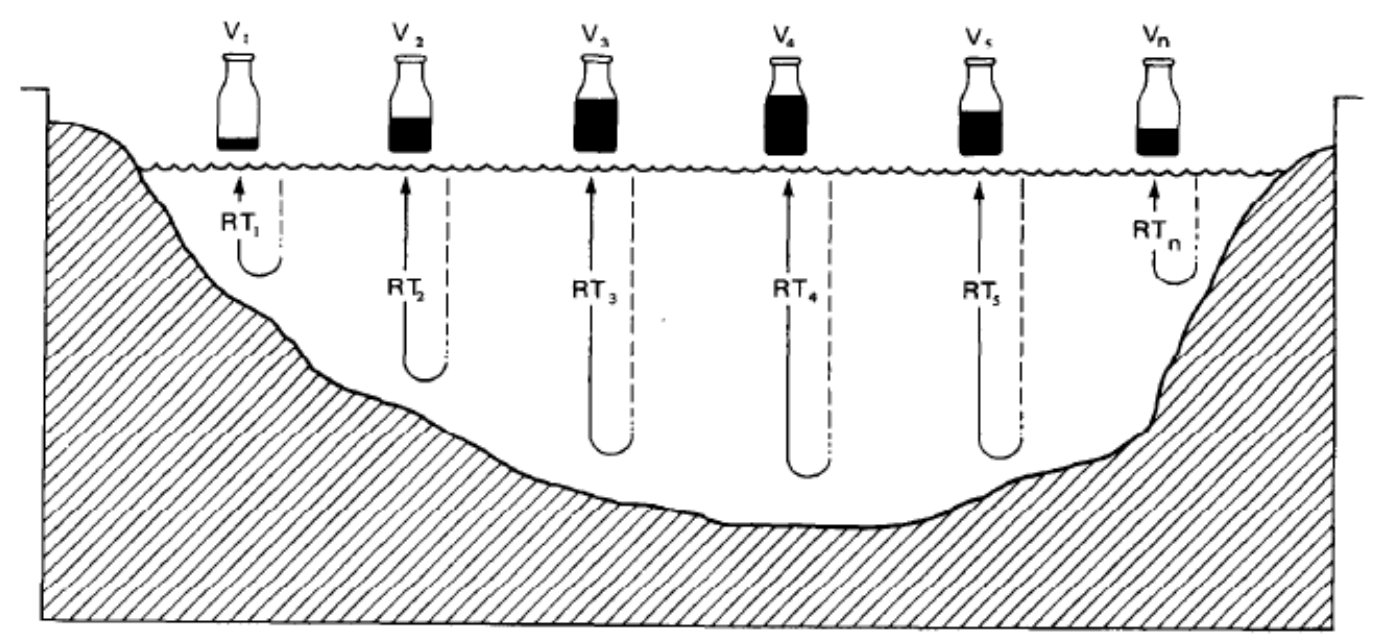

Figura 9: Método de Igual-Incremento-Largura. Fonte: Edwards e Glysson, 1999.

Neste método uma amostragem completa de sedimento em suspensão não será completa, pois os amostradores não devem alcançar o leito para não coletarem sedimento de arrasto, desta forma sempre ficará uma zona de 09 a $15 \mathrm{~cm}$ sem ser amostrada. Normalmente, cada amostrador, pelas suas características físicas, tem a "profundidade não amostrada" medida desde o bico até a parte inferior do aparelho. 
Outro método utilizado no desenvolvimento desta pesquisa foi o pontual central, este se resume em realizar uma amostragem na vertical central da seção transversal do rio. Este método é cada vez mais utilizado, principalmente em regiões de difícil acesso (ROIG, 2005). Utilizou-se este método a fim de realizar comparações de procedimentos de amostragem de sedimento em suspensão, assim sendo, foi aplicado nos três pontos de amostragem (córrego Taquara, córrego Capetinga e Ribeirão do Gama). A seguir é exposto um quadro demonstrativo dos tipos de medições passíveis de serem realizadas em corpos hídricos.

Tabela 4: Tipo de medições de sedimentos, suas descrições e equipamentos mais utilizados nas coletas realizadas no Brasil. Fonte: Modificado de Carvalho, 1994 apud Carvalho, 2000.

\begin{tabular}{|c|c|c|}
\hline Medição & Descrição & Equipamento ou metodologia de medida \\
\hline \multirow[t]{2}{*}{ Direta } & $\begin{array}{l}\text { Usa equipamentos que medem } \\
\text { diretamente o curso d'água, a } \\
\text { concentração ou outra grandeza } \\
\text { como a turbidez ou ultra-som. }\end{array}$ & $\begin{array}{l}\text { Medidos nuclear (portátil ou fixo), ultra- } \\
\text { sônico ótico, ultra-sônico Doppler de } \\
\text { dispersão, turbidímetro e ADCP (Doppler). }\end{array}$ \\
\hline & $\begin{array}{l}\text { Por acumulação do sedimento } \\
\text { medidos (proveta graduada). }\end{array}$ & $\begin{array}{l}\text { Garrafa Delft (medição pontual e } \\
\text { concentração alta) ou outro tipo de garrafa } \\
\text { que a substitua. }\end{array}$ \\
\hline \multirow[t]{2}{*}{ Indireta } & $\begin{array}{l}\text { Coleta de sedimento por } \\
\text { amostragem da mistura água e } \\
\text { sedimento, análise de } \\
\text { concentração e granulometria e, } \\
\text { cálculos posteriores da descarga } \\
\text { sólida. }\end{array}$ & $\begin{array}{l}\text { Equipamentos: de bombeamento } \\
\text { equipamentos que usam garrafas ou sacas, } \\
\text { sendo pontuais instantâneos, pontuais por } \\
\text { integração e integradores na vertical (no } \\
\text { Brasil usa-se principalmente a série norte- } \\
\text { americana - U-59, UH-48, DH-59, D-49, P- } \\
61 \text { e amostradores de saca). }\end{array}$ \\
\hline & $\begin{array}{l}\text { Uso de imagens de satélite e } \\
\text { comparação com medidas } \\
\text { simultâneas de campo para } \\
\text { calibragem, em grandes rios. }\end{array}$ & $\begin{array}{l}\text { São estabelecidas equações que } \\
\text { correlacionam as grandezas de observação } \\
\text { das imagens com as concentrações } \\
\text { medidas. }\end{array}$ \\
\hline
\end{tabular}

Desta forma, observa-se que o método a ser aplicado está intimamente ligado ao objeto e objetivo de cada pesquisa, sendo necessário ainda conhecimento prévio da área de estudo para identificar as possíveis dificuldades de campo e de aplicação metodológica. 
Dos equipamentos integradores na vertical elencados na (Tabela 4) apenas os amostradores USDH-48 e USDH-59 foram utilizados nesta pesquisa, pois eram os que estavam disponíveis e porque atenderam bem as necessidades em campo.

O amostrador USDH-48 é construído em alumínio com corpo de forma hidrodinâmica, tendo haste para operação a vau ou de canoa, em profundidades baixas, até $2,7 \mathrm{~m}$ a 4,5m, utilizado para integração na vertical em dois sentidos. Utiliza bico de 1/4", 3/16" e 1/8" e garrafa de 0,51 , sendo a distância do bico ao fundo do amostrador igual a $0,091 \mathrm{~m}$. Como é leve, só pode ser usado em condições de baixa velocidade pelo processo de integração na vertical (CARVALHO et.al. 2000).

O USDH-59, que é um equipamento de bombeamento, sendo pontual instantâneo, pontual por integração e integradores na vertical também é leve, fabricado em bronze, com forma hidrodinâmica, para uso em suspensão com guincho instalado em canoa, podendo ainda ser utilizado de forma manual. Utiliza os três bicos padrões e garrafa de 0,51 , sendo a distância do bico ao fundo do amostrador igual a $0,102 \mathrm{~m}$. Por ser leve, só pode ser usado em condições de baixa velocidade pelo processo de integração na vertical em dois sentidos e até 4,5m (CARVALHO et.al. 2000).

\subsection{0- Vazão}

A vazão é uma variável extremamente sensível aos fatores contribuintes ao seu aumento ou diminuição, dependendo do tipo de canal as reações podem gerar tanto eventos que provocam o aumento de sua carga quanto os que contribuem para a diminuição da lâmina d'água.

Desta forma a variável vazão pode ser definida como a quantidade volumétrica $\left(\mathrm{m}^{3}\right)$ de um fluido que escoa através de uma seção de um canal ou tubulação por unidade de tempo (s), ou seja, é a rapidez com que, no caso, um volume de água do rio escoa. A medição de vazão em uma seção fluviométrica se dá da seguinte forma, primeiramente, mede-se o comprimento de uma margem a outro do canal, em seguida, define-se a largura entre as verticais (CARVALHO et.al, 2000; TUCCI, 2013). 


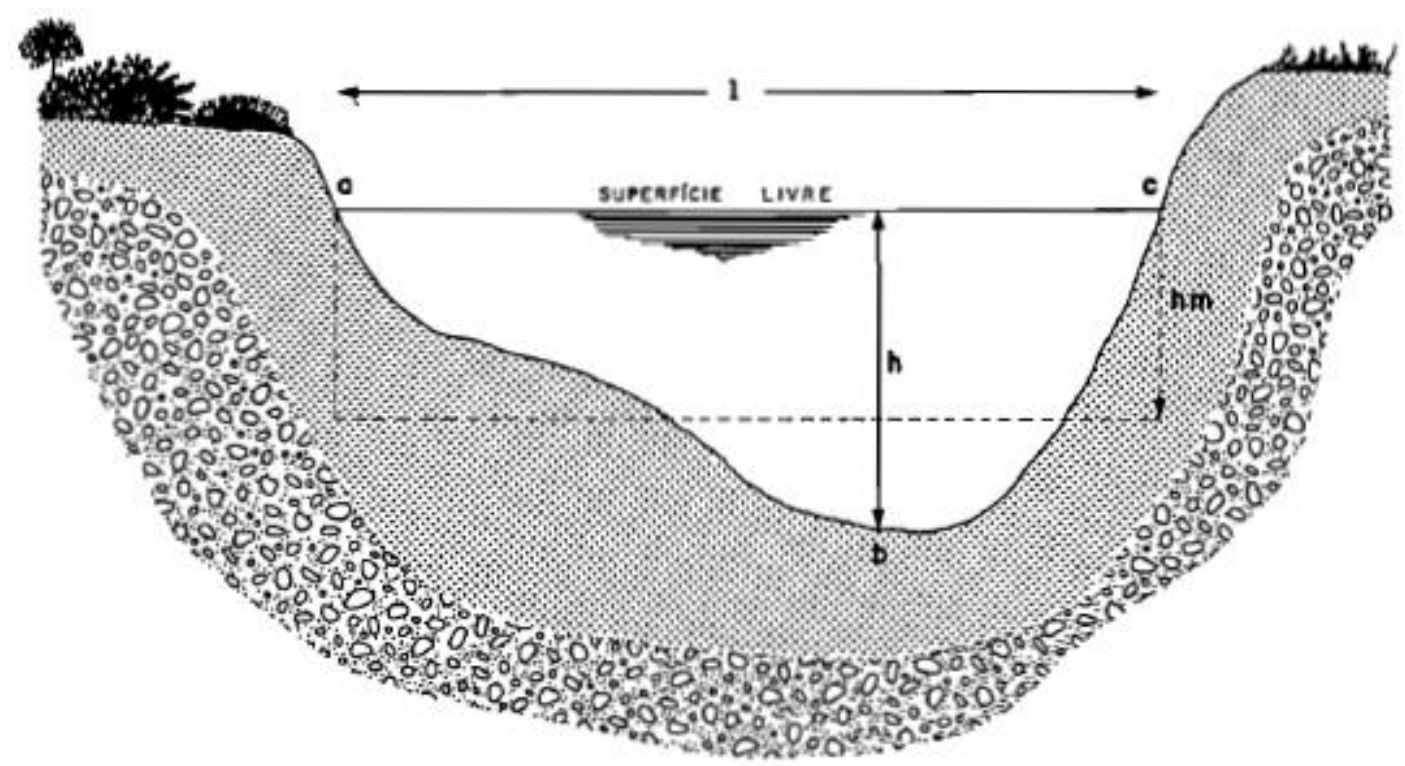

Figura 10: Seção de medição de vazão. L - Comprimento de uma margem a outra; $\mathrm{h}$ - Altura da superfície da lâmina d'água até o leito do canal, hm: Altura média da lâmina d'água. Fonte: Jaccon e Cudo, 1989.
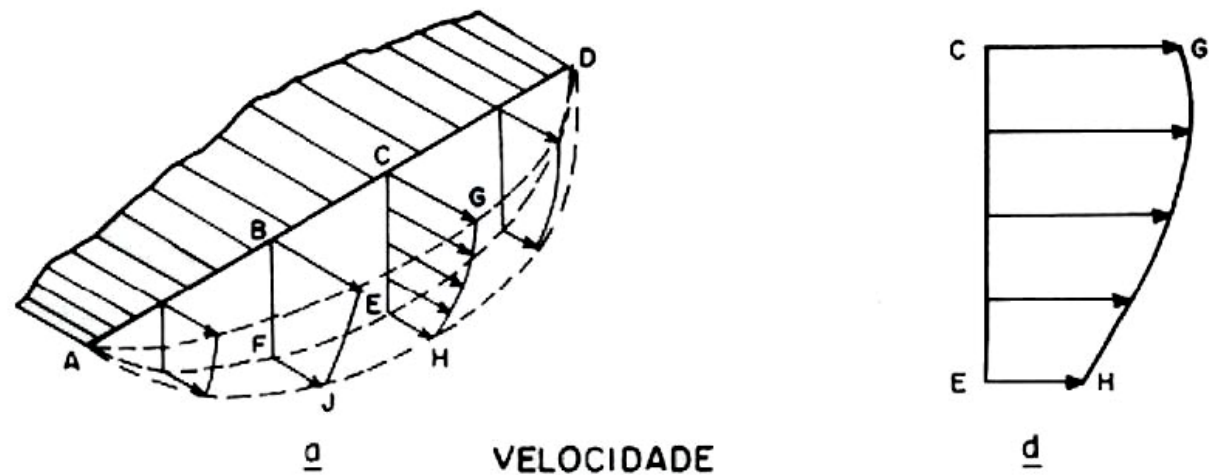

Figura 11: Seção transversal de canal e suas verticais. De A a D - Largura do canal; E a J - Pontos das verticais onde serão realizadas as medições da velocidade do fluxo. Fonte: Carvalho et.al. 2000.

A correlação desta variável com a concentração de sedimentos é estreita, pois variam em constâncias semelhantes, ou seja, suas respostas a entrada da pluviosidade são extremamente sensíveis, variando no tempo e no espaço, configurando relação diretamente proporcional entre si (LOPES, 2007).

A contribuição oriunda da precipitação pode ser avaliada por meio da cota e da vazão nos momentos em que ocorrem os eventos de pico de chuva, para isso existem aparelhos que realizam estas medições, alguns são automáticos outros são manuais, como exemplo, pode-se citar os linígrafos, que registram a altura da lâmina d'água no decorrer do tempo de forma automática (TUCCI, 2013), com o uso de vertedouros, Acoustic Doppler Current (ADC),que mede a vazão em tempo real, radar que também mede o nível da coluna d'água, dentre outros (SIGNELL, 2012). 


\subsection{1- Curva-Chave de Vazão}

Relacionando as variáveis nível e vazão é possível estabelecer curva-chave para os rios, uma vez que esta é estabelecida de forma indireta pela relação entre a cota-vazão auferida em uma determinada seção molhada e o seu resultado é uma hidrógrafa, que representa as flutuações de vazão em função do tempo, além de permitir distinguir o escoamento superficial do escoamento de base (BRUSA e CLARKE, 1999; PORTO et.al, 2001).

No âmbito da ciência hidrológica, a curva-chave é a representação gráfica da relação cota-descarga a partir de umas medições distribuídas em um intervalo de cotas ao longo do tempo em que o rio ascende e baixa, a fim de abranger tanto os pontos de cota alta e baixa (JACCON \& CUDO, 1989; CHEVALLIER,2004;).

De acordo com Chevallier (op.cit.), a representação mais usual no meio acadêmico desta relação é a representação gráfica $\mathrm{h} / \mathrm{Q}$, onde h é a cota e $\mathrm{Q}$ representa a vazão. Toda esta relação cota $X$ descarga pode ser representada, na sua totalidade ou por trechos sucessivos, através de expressões matemáticas, as formas mais frequentes são expressões exponencial e a polinomial.

A seguinte expressão exponencial é frequentemente citada na literatura para a elaboração da curva-chave de vazão (CARVALHO, 1994; CARVALHO 2001; TUCCI, 2001):

\section{a) exponencial:}

$$
\mathbf{Q}=\mathbf{a} \cdot(\mathbf{H}-\mathbf{H o})^{\mathbf{b}}
$$

Onde: $a$, $b$ e Ho são parâmetros de ajuste da seção fluviométrica de interesse; $H$ : Nível do rio $(m)$; $Q$ : Vazão $\left(\mathrm{m}^{3} \cdot \mathrm{s}^{-1}\right)$, o parâmetro $H o$ é o nível da régua para o qual a vazão é nula.

\section{b) polinomial:}

$$
Q=a_{0}+a_{1} h+a_{2} h^{2}+a_{3} h^{3}+\ldots+a_{n} h^{n}
$$

Onde $\left(\boldsymbol{a}_{\boldsymbol{i}}\right)$ são as constantes da função polinomial e $(\boldsymbol{n})$ é o grau do polinômio, $(\boldsymbol{h})$ é a cota.

De acordo com Paiva et. al. (2001), a qualidade da informação fluviométricas depende da eficiência da curva-chave, a qual depende do escoamento, logo quanto maior a frequência de mensuração e coletas, melhor são os resultados adquiridos. 


\subsection{2 - Monitoramento Sedimentológico}

Usualmente pesquisas que desenvolvem medições de vazão também realizam coletas de sedimentos, pois desta forma otimizam o trabalho de campo e os operados em campo, visto que este tipo de trabalho é caro e demorado. Para a coleta de sedimentos, assim como a de vazão existem vários métodos de amostragem, dependendo apenas das características e tipo de estudo a se realizar, eles subdividem-se em métodos diretos e indiretos.

De acordo com Carvalho (1994) no Brasil a sedimentometria tem sido realizada, tradicionalmente, por amostragem de sedimento, análise em laboratório e cálculos de obtenção da descarga sólida, sendo caracterizada como método indireto.

Os métodos diretos são aqueles realizados em campo com a utilização de equipamentos que obtém diretamente a concentração ou outra grandeza como a turbidez. De acordo com Simões e Coiado (2001), os aparelhos devem estar adequadamente calibrados e no instante da medição estes não devem perturbar o escoamento, possibilitando que a coleta seja realizada na mesma velocidade do fluxo.

A estimativa da produção de sedimentos de uma bacia hidrográfica pode ser realizada a partir da avaliação do desprendimento, do transporte e da deposição deste material sedimentológico. Todavia, na maioria dos casos, as medidas são feitas diretamente pelo monitoramento da descarga total de sedimentos transportados pelo canal no exutório da bacia, durante um período de tempo (MINELLA, 2007).

Os autores Merten et al. (2006); Carvalho (2000) e Tomaz (op.cit.) trazem que uma estimativa baseada em amostragem trimestral não corresponde à estimativa de amostragem semanal, diária ou horária, podendo haver uma subestimativa da produção de sedimentos quanto menor for o intervalo entre as medidas. Estes autores relatam ainda que, o intervalo mínimo que deve existir entre uma amostragem e outra é de um mês, privilegiando os períodos chuvosos.

Tradicionalmente, a metodologia utilizada no monitoramento hidrossedimentométrico é configurada na obtenção e organização de uma base de dados formada por uma série temporal de precipitação, vazão e concentração de sedimentos.

A base de dados possibilita o cálculo do fluxo de sedimentos, caracterizado pela descarga sólida de sedimentos em suspensão (massa por unidade de tempo) e a produção de sedimentos, que é a integração do fluxo de sedimentos em determinado tempo. 
A qualidade dos resultados será melhor quanto maior for a frequência de amostragem e sua extensão no tempo. Um número maior de amostras em menor intervalo de tempo aumenta a probabilidade de coincidir o momento da coleta com os eventos de cheia, os quais são os principais responsáveis pela maior parte da produção e transporte de sedimentos (CHRISTOFOLETTI, 1980; CARVALHO, 1994; LEOPOLD et al., 1995; CARVALHO, 2001; MINELLA, op. cit.,).

\subsection{3 -Curva-Chave de Sedimentos em Suspensão Instantânea}

Concomitante a curva-chave de vazão pode-se estabelecer a curva-chave de sedimentos, pois a carga sedimentar e a vazão são variáveis interligadas e apresentam respostas conexas.

Traçar uma curva-chave de sedimentos é estabelecer uma relação entre vazão e concentração de sedimentos instantânea para poder estimar o fluxo de sedimentos (CARVALHO, 1994; PHILLIPS et al., 2000). Carvalho (1994) e Carvalho (2014) estabelecem que para adquirir a descarga sólida em suspensão é necessário realizar o produto da concentração de sedimentos em suspensão pela vazão líquida medida no momento da amostragem.

Todavia adquirir estes dados não é uma atividade simples de se realizar, tal como exposto na literatura, Carvalho (1994); Fill e Santos (2001); Chella (2005); Paiva (2007); Minella (2008), entre outros pesquisadores. É necessária a realização de coleta e análise de amostras (maior número possível), valorizando períodos de cheia, momento no qual ocorrem os picos de carga sedimentar.

Para obter um resultado coerente e condizente à realidade, conforme expõe Carvalho (1994), é necessário uma série temporal longa e contínua da descarga sólida e líquida, tradicionalmente, esta é determinada através da curva-chave de sedimentos que relaciona descarga sólida em suspensão e vazão líquida, quanto maior a quantidade de dados obtidos melhor será a resposta apresentada.

Carvalho (op.cit) afirma que entre os métodos mais utilizados para traçar a curva destacam-se o traçado visual e a regressão linear. Segundo o mesmo autor, é importante que se faça uma análise gráfica preliminar antes que se faça o tratamento matemático, verificando se os pontos permitem o traçado de mais de uma curva e se eles cobrem bem os pontos de estiagem e de cheias, ademais de se verificar se há quantidade de números adequados de pontos. 
Caso não se consiga atingir a qualidade nestes parâmetros, a curva-chave de sedimentos será prejudicada, tal como ocorrido com Bellinaso e Paiva (2007), cuja quantidade de dados foi insuficiente, gerando curva-chave de sedimentos inadequada. Já em Chella et.al. (2005) a autora ressalta que a curva de descarga sólida não representou adequadamente as condições de transporte de sólidos exigindo mais dados.

Corriqueiramente, nas pesquisas relacionadas à essa temática, é adotado o método simplificado de Colby (1957), o qual é derivado do método modificado de Einstein (1955) para o cálculo da descarga sólida em suspensão.

Neste método, a velocidade de movimento da partícula de sedimento é considerada a mesma que a velocidade da corrente em toda a seção transversal, ficando então igual ao produto da descarga líquida pela concentração. Quando se tem a concentração média obtida através de amostragens pelos métodos de Igual Incremento Largura ou Igual Incremento Descarga, conforme equação a seguir:

\section{Qss $=0,0864 \times$ x $\times$ Cs}

Onde:

Qss - Descarga sólida total em ton. dia $^{-1}$;

$\mathbf{0 , 0 8 6 4}$ - Constante de correção de unidades (transforma as unidades de segundos por dia e gramas para toneladas).

Q - Descarga líquida em $\mathrm{m}^{3} \cdot \mathrm{s}^{-1}$;

Cs - Concentração media em mg. $\mathrm{L}^{-1}$ ou ppm.

Após a plotagem dos pares de pontos $Q s s / Q$, a curva-chave é traçada, mediante equações que busquem apresentar a tendência dos valores apresentados. As equações de ajuste podem ser do tipo linear $(Q s s=b \cdot Q)$, polinomial $\left(Q s s=a \cdot Q^{2}+b \cdot Q\right)$ ou potencial $\left(Q s s=a \cdot Q^{b}\right)$.

Chow et. al. (1988) alerta que, independente da correlação gerada, todas as curvas de correlação precisam ser checadas periodicamente, devido as diferenças que podem ocorrer com a transformação do perfil de escoamento ou de características da bacia hidrográfica, ou seja, o monitoramento realizado pelo hidrometrista deve ser permanente.

Desta forma compreende-se que este tipo de estudo e monitoramento são importantes para compreender, cuidar e sugerir ações de preservação dos sistemas hídricos, principalmente de pequenas bacias mantenedoras de lagos e reservatórios, visto que a desestabilização destas pequenas bacias acarreta consequências drásticas para os corpos hídricos receptores, tal como 
contaminação por materiais tóxicos, eutrofização de lagos, assoreamento, comprometimento de usinas hidrelétricas e adutoras, dentre outras consequências. 


\title{
5- Artigo
}

\section{Análise da Resposta do Regime Hídrico/Sedimentar na Bacia Hidrográfica do Ribeirão do Gama/DF, durante o ano de 2014}

\author{
Isabela Catarina de Souza \\ Programa de Pós-Graduação em Geografia - Departamento de Geografia - Instituto de \\ Ciências Humanas - Universidade de Brasília - Campus Universitário Darcy Ribeiro, \\ Brasília - DF - CEP 70910-900. Telefone (61) 3107-7257. \\ E-mail: isabelacadastro26@gmail.com
}

\section{Resumo}

O monitoramento sedimentológico na bacia do Ribeirão do Gama e suas sub-bacias (córrego Taquara e córrego Capetinga) foi realizado durante o período de 2014 a 2015. Neste intervalo, foram realizadas coletas mensais de sedimentos em suspensão, pelos métodos igual incremento largura, vertical central e o amostrador automático ISCO 6712. Os aparelhos utilizados nas coletas manuais foram o USDH-48 e o USDH-59, os quais são os mais utilizados no Brasil para pesquisas em pequenos rios. Com isto, buscou-se identificar a correlação entre a descarga líquida e o transporte de sedimento em suspensão para as três bacias. Os resultados encontrados revelaram constância na carga sedimentar tanto no período chuvoso quanto no de seca, tendo como maior destaque, a seção fluviométrica do Ribeirão do Gama, no qual a carga sedimentar em suspensão aferida pelo método da vertical central revelou-se superior àquela obtida pelo método do igual incremento largura. Por fim, foi verificado que a bacia do Ribeirão do Gama contribui com baixa quantidade de sedimentos em suspensão para o Lago Paranoá, principalmente na estação seca.

Palavras-Chave: Produção de Sedimentos; Pequenas Bacias; Recursos Hídricos.

\begin{abstract}
The sedimentological monitoring in the basin of Ribeirão Gama and their sub-basins (Taquara stream and Capetinga stream) was conducted during the period 2014-2015. In the meantime, monthly collections of suspended sediments load were carried out using the methods equal increment width, vertical center and the autosampler ISCO 6712. The devices used in the
\end{abstract}


manual collections process were the USDH-48 and USDH-59, which are the most used in Brazil for research on small rivers. Furthermore, we sought to identify the correlation between the liquid discharge and sediment transport in suspension for the three basins. The results showed constancy in the sediment loads in both rainy and in the dry seasons, with the biggest highlight of this relationship and evidence, the fluviometric section of Ribeirão Gama, where the suspended sediment load acquired by the central vertical method presented higher than the same width increment method. Finally, it was revealed that the contribution of Ribeirão Gama basin sums a low amount of sediment load Lake Paranoá, especially in the dry season.

Keywords: Sediment Production; Small basin; Water Resources.

\section{1- Introdução}

O transporte de sedimentos e a deposição das partículas sólidas em rios integram o processo de erosão e sedimentação, esses são fenômenos complexos que dependem dos processos atuantes nas vertentes da bacia, das forças que agem sob as partículas (gravidade, inércia e fricção) e nas margens e leitos dos rios (SANTOS et al., 1991).

O monitoramento da carga sedimentar em pequenas bacias serve de ponto de partida para a elaboração de medidas que visem à maximização do uso dos recursos disponíveis, à minimização dos efeitos negativos decorrentes da produção, transporte e deposição de sedimentos, tal como o assoreamento, a contaminação e a eutrofização de corpos hídricos (BRANCO, 1998).

O deslocamento desse material até os lagos e rios maiores depende da energia do fluxo, que é determinada por alguns fatores, dentre os quais a Lei de Stokes ${ }^{1}$, que se relaciona com a força gravitacional e a friccional. A primeira destas provoca o fluxo da água e a segunda limita a movimentação das partículas ao longo dos canais; são elas, juntamente com a constante do número de Reynolds ${ }^{2}$, que determinam a variação no tempo e no espaço das partículas de

$1 \vec{F}=-6 \pi r \eta \vec{v}$ : Onde: $\vec{F}$ : é a força de fricção; $r$ é o raio da partícula; $\eta$ : é a viscosidade do fluido; $\vec{v}$ : é a velocidade da partícula.

$\mathbf{2} \mathfrak{R}=\frac{\rho f d v}{\eta}$ Onde: $\rho \mathbf{f}:$ massa específica do fluido [kg.m-3]; D: dimensão linear típica ou diâmetro

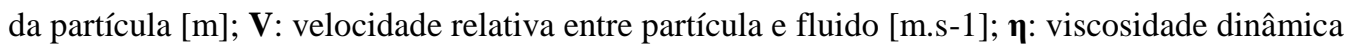
[Pa.s=kg.m-1s-2]. 
sedimento, sua decantação e a vazão dos cursos hídricos (CHORLEY, SCHUMM \& SUGDEN, 1984; LEOPOLD, WOLMAN, MILLER, 1995; SANTOS et al., 1991, CARVALHO, 1994).

Os métodos utilizados para monitorar as bacias foram os mais utilizados no Brasil: o método do Igual Incremento Largura - IIL e o método da Vertical Central. Os equipamentos utilizados nas coletas de sedimento em suspensão foram o USDH-48 e o USDH-59 (CARVALHO, 2001).

Estudar esses fenômenos na Bacia do Ribeirão do Gama torna-se importante pelo fato deste Ribeirão desaguar na bacia do Lago Paranoá. Como unidade de uso múltiplo, o Lago Paranoá caracteriza-se como um corpo hídrico que permite lazer, umidade, energia e multiplicação de espécies de animais/vegetais (CONSÓRCIO THEMAGNA, 2009). Isto justifica a importância de se compreender o comportamento hidrossedimentológico da bacia do Ribeirão do Gama por meio da quantificação da carga sedimentar e pela elaboração de sua curva-chave de descarga líquida, uma vez que o Lago Paranoá, ademais de todos seus usos será utilizado para o abastecimento hídrico humano do DF.

Diante do exposto, o objetivo deste estudo compreendeu a obtenção, análise e correlação das características pluvio-fluvio-sedimentométricas da bacia hidrográfica do Ribeirão do Gama e de suas sub-bacias Córrego Taquara e Córrego Capetinga.

\section{2 - Material e Métodos Aplicados}

\subsection{1 - Caracterização da Área de Estudos}

A bacia hidrográfica do Ribeirão do Gama situa-se no Distrito Federal e é tributária do Lago Paranoá (Figura 12); ocupando uma área de 147,81 $\mathrm{Km}^{2}$. Ela apresenta diferentes tipos de uso do solo (Tabela 5), tais como: áreas de preservação (Reserva Ecológica do IBGE, Fazenda Experimental da UnB - Água Limpa e Estação Ecológica do Jardim Botânico); áreas urbanizadas (setor de mansões do Park Way); áreas agrícolas contendo importantes polos hortigranjeiros (Núcleo Rural Vargem Bonita e Núcleo Rural do Córrego da Onça); além de Áreas de Relevante Interesse Ecológico (ARIE's dos córregos Capetinga e Taquara) e o Aeroporto Internacional JK (CARVALHO et al, 2001) (Figura 15, Tabela 5). 
Tabela 5: Porcentagem dos usos de solos das bacias hidrográficas estudadas.

\begin{tabular}{c|c|c|c}
\hline Usos do Solo & $\begin{array}{c}\text { Ribeirão do } \\
\text { Gama (\%) }\end{array}$ & $\begin{array}{c}\text { Córrego } \\
\text { Taquara (\%) }\end{array}$ & $\begin{array}{c}\text { Córrego } \\
\text { Capetinga (\%) }\end{array}$ \\
\hline $\begin{array}{c}\text { Área de baixa } \\
\text { densidade urbana }\end{array}$ & $1,95 \%$ & 0,21 & 0,44 \\
\hline $\begin{array}{c}\text { Área de média } \\
\text { densidade urbana }\end{array}$ & $6,73 \%$ & - & - \\
\hline $\begin{array}{c}\text { Área de alta } \\
\text { densidade urbana }\end{array}$ & $2,56 \%$ & - & - \\
\hline Campo & $29,92 \%$ & 27,00 & 53,38 \\
\hline $\begin{array}{c}\text { Campo de murundus/ } \\
\text { Áreas alagáveis }\end{array}$ & $2,01 \%$ & 1,54 & 0,80 \\
\hline Cerrado & $38,75 \%$ & 58,05 & 22,60 \\
\hline Olericultura & $4,28 \%$ & 3,59 & 4,54 \\
\hline Mata galeria & $5,18 \%$ & 5,51 & 10,50 \\
\hline Pasto & $3.80 \%$ & 2,77 & 6,41 \\
\hline Solo exposto & $0,07 \%$ & - & 0,09 \\
\hline Vias não pavimentadas & $0.68 \%$ & 1,25 & 1,16 \\
\hline Vias Pavimentadas & $2,39 \%$ & 0,08 & 0,09 \\
\hline
\end{tabular}

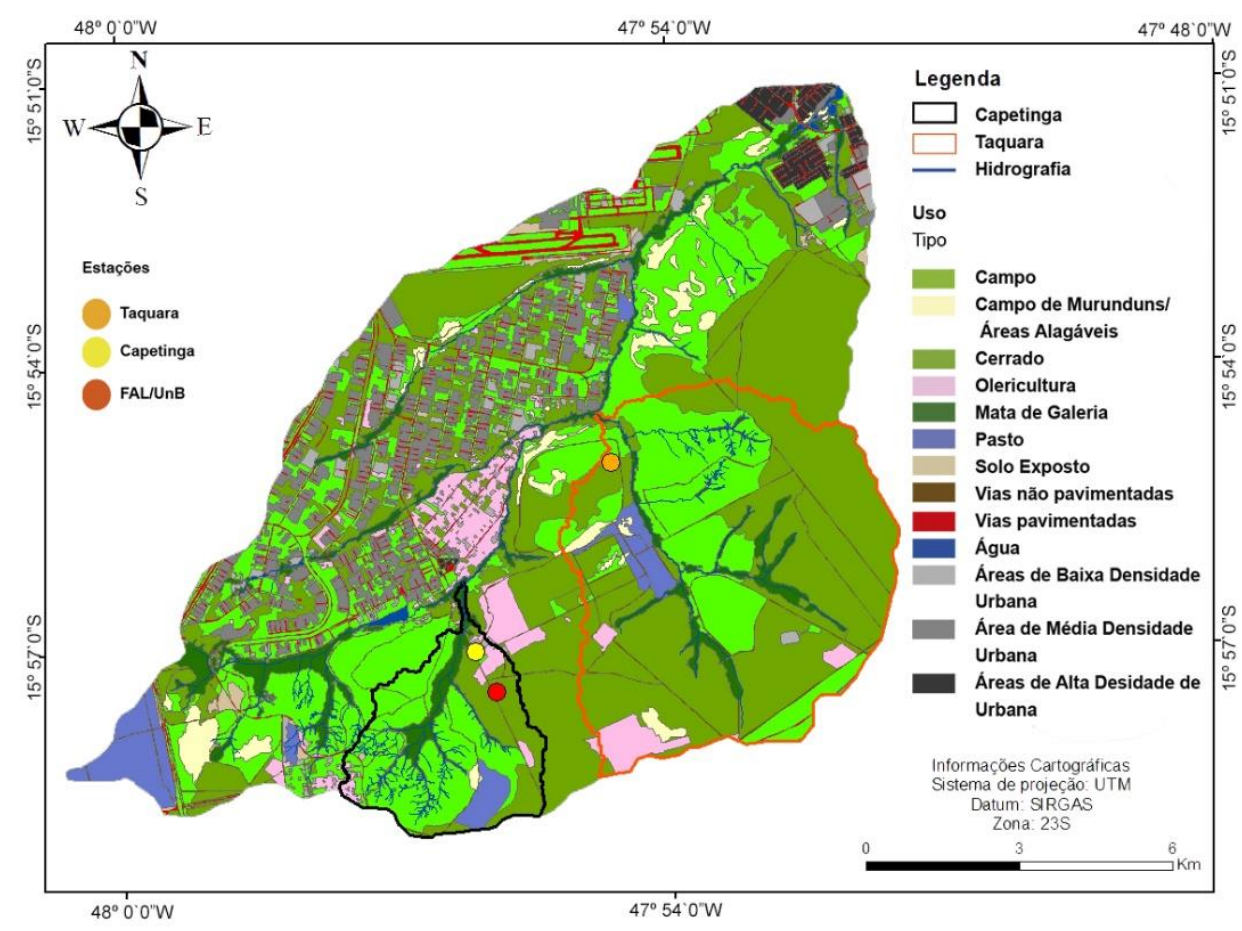

Figura 12: Mapa de uso dos solos - Bacia Ribeirão do Gama. Vetorizado na escala: 1:10.000. 

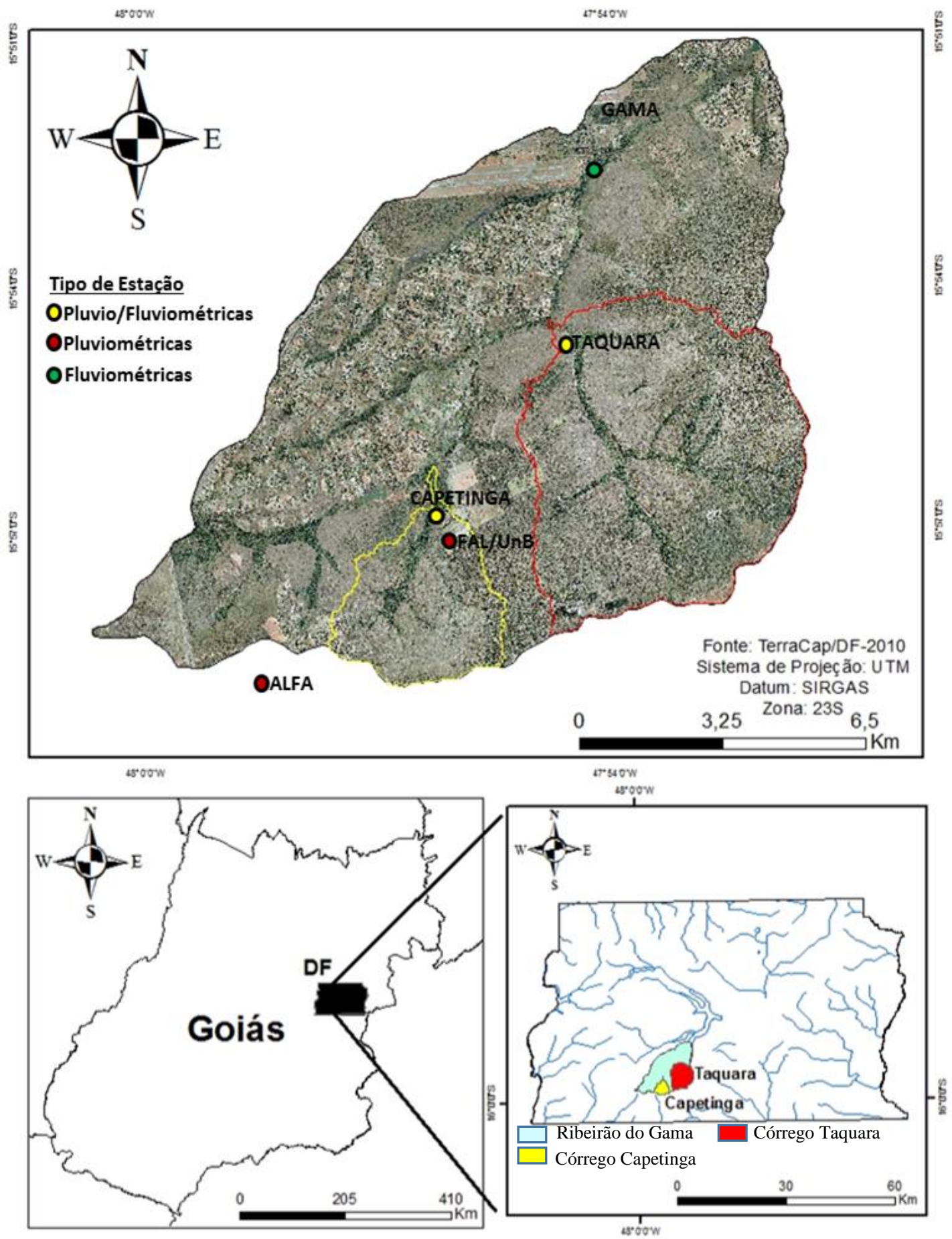

Figura 13: Mapa de localização da área de estudos. Bacia do Ribeirão do Gama, com bacia do córrego Capetinga (amarelo) e bacia do córrego Taquara (vermelho).

O clima do Distrito Federal mostra-se sazonal com duas estações bem definidas: (a) estação seca, de maio a setembro, caracterizada por baixa insolação, pouca nebulosidade, acentuada evaporação, baixos teores de umidade no ar, pluviosidade reduzida e grande amplitude térmica; e (b) estação chuvosa, de outubro a abril, caracterizada por elevada insolação, maior nebulosidade, evaporação reduzida, maiores teores de umidade no ar, maior 
pluviosidade e menor amplitude térmica, pois as máximas mantêm-se e as mínimas elevam-se (BARROS, 2003). As precipitações variam entre 1.500 e $1.750 \mathrm{~mm} / \mathrm{ano}$, com média em torno de $1.600 \mathrm{~mm} /$ ano. A (Figura 13) mostra o regime pluviométrico médio da bacia hidrográfica do Ribeirão do Gama para os anos de 1\%/1979 a 1\%/2015, onde fica claro o comportamento sazonal.

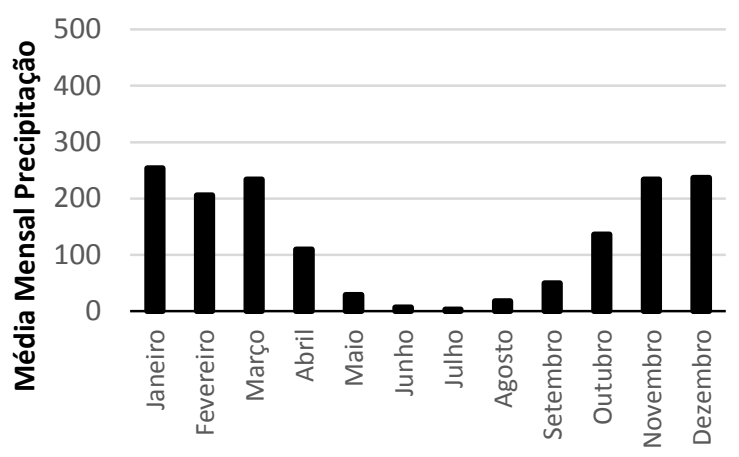

Média Mensal

Figura 14: Média mensal - bacia hidrográfica Ribeirão do Gama - Estação pluviométrica Área Alfa (1979 2015).

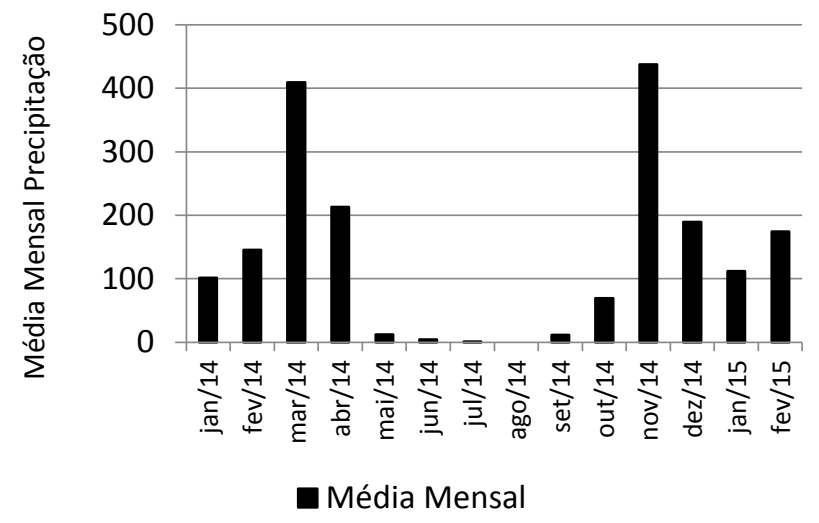

Figura 15: Média mensal precipitação (01/2014- 02/2015) bacia hidrográfica do Ribeirão do Gama - Estação pluviométrica - Área Alfa.

Entretanto, para o período pesquisado $\left(1^{\circ} / 2014-1^{\circ} / 2015\right)$, o acumulado das chuvas foi distinto com médias mensais reduzidas e com apenas dois grandes picos (março $-410 \mathrm{~mm}$ e novembro - $440 \mathrm{~mm}$ ); essa particularidade interferiu nos resultados hidrossedimentológicos encontrados para as bacias estudadas (Figura 14).

A bacia do Ribeirão do Gama contém três unidades geológicas na escala 1:250.000 (Campos, 2005): Metarritimito Arenoso; Ardósia e Quartzito Médio (Figura 18). As sub-bacias do Córrego Capetinga e Córrego Taquara possuem predominância da Unidade Metarritimito Arenoso (Figura 18).

O padrão de drenagem predominante é o dendrítico, o qual se desenvolveu sobre as rochas metassedimentares sub-horizontais em associação às fraturas subverticais nas charneiras das dobras. Nas regiões arenosas do Metarritmito e do Quartzito estão localizadas as cabeceiras dos rios, que são muito fraturadas; as Fraturas seguem orientação NE-SW e NW-SE (FREITASSILVA E CAMPOS, 1999).

A área estudada possui duas unidades geomorfológicas predominantes: Chapadas e dissecação intermediária do grupo Paranoá (MARTINS et al., 2004). A chapada é caracterizada por relevos planos a suave-ondulados, com baixa densidade de drenagem devido à baixa 
dissecação, e formada principalmente por Latossolos. Outro processo verificado na área estudada é a pediplanação - Superfícies Residuais de Aplainamento nas cotas mais elevadas, o que compreende a sub-bacia do Córrego Capetinga; Depressões Interplanálticas e Planícies (CODEPLAN, 1984) (Figura 18 A e B).

O mapa pedológico da bacia do Ribeirão do Gama foi elaborado na escala 1:100.000 pela EMBRAPA (2004). Tanto a bacia do Ribeirão do Gama quanto a sub-bacia do córrego Taquara são constituídas em sua maioria por Latossolo Vermelho (40,3\% - Ribeirão do Gama; 40,33\% - Taquara), seguido pelo Cambissolo (22,3\% - Ribeirão do Gama; 20,22\% Taquara) e Latossolo Vermelho-Amarelo (21,1\% Ribeirão do Gama; 28,85\% - Taquara); em menor proporção há o Plintossolo no Ribeirão do Gama $(0,3 \%)$ e no córrego Taquara os Solos Hidromórficos (10,60\%) (Tabela 6 e Figura 17 A).

Mediante essa informação é possível afirmar que o solo da sub-bacia do córrego Taquara e do Ribeirão do Gama, de forma geral, são bem desenvolvidos, visto que predomina o Latossolo-Vermelho e na sub-bacia do córrego Capetinga há o predomínio da classe Cambissolo, o qual é do tipo material de origem e está muito próximo da superfície.

Tabela 6: Porcentagem das classes de solos para cada Bacia hidrográfica.

\begin{tabular}{c|c|c|c}
\hline Solo & $\begin{array}{c}\text { Ribeirão do } \\
\text { Gama (\%) }\end{array}$ & $\begin{array}{c}\text { Córrego } \\
\text { Taquara (\%) }\end{array}$ & $\begin{array}{c}\text { Córrego } \\
\text { Capetinga (\%) }\end{array}$ \\
\hline Cambissolo & $22,3 \%$ & 20,22 & 42,06 \\
\hline Latossolo Vermelho & $40,3 \%$ & 40,33 & 16,77 \\
\hline Latossolo Vermelho-Amarelo & $21,1 \%$ & 28,85 & 21,12 \\
\hline $\begin{array}{c}\text { Solo Hidromórficos } \\
\text { Indiscriminados }\end{array}$ & $16 \%$ & 10,60 & 20,05 \\
\hline Plintossolo & $0,3 \%$ & - & - \\
\hline
\end{tabular}



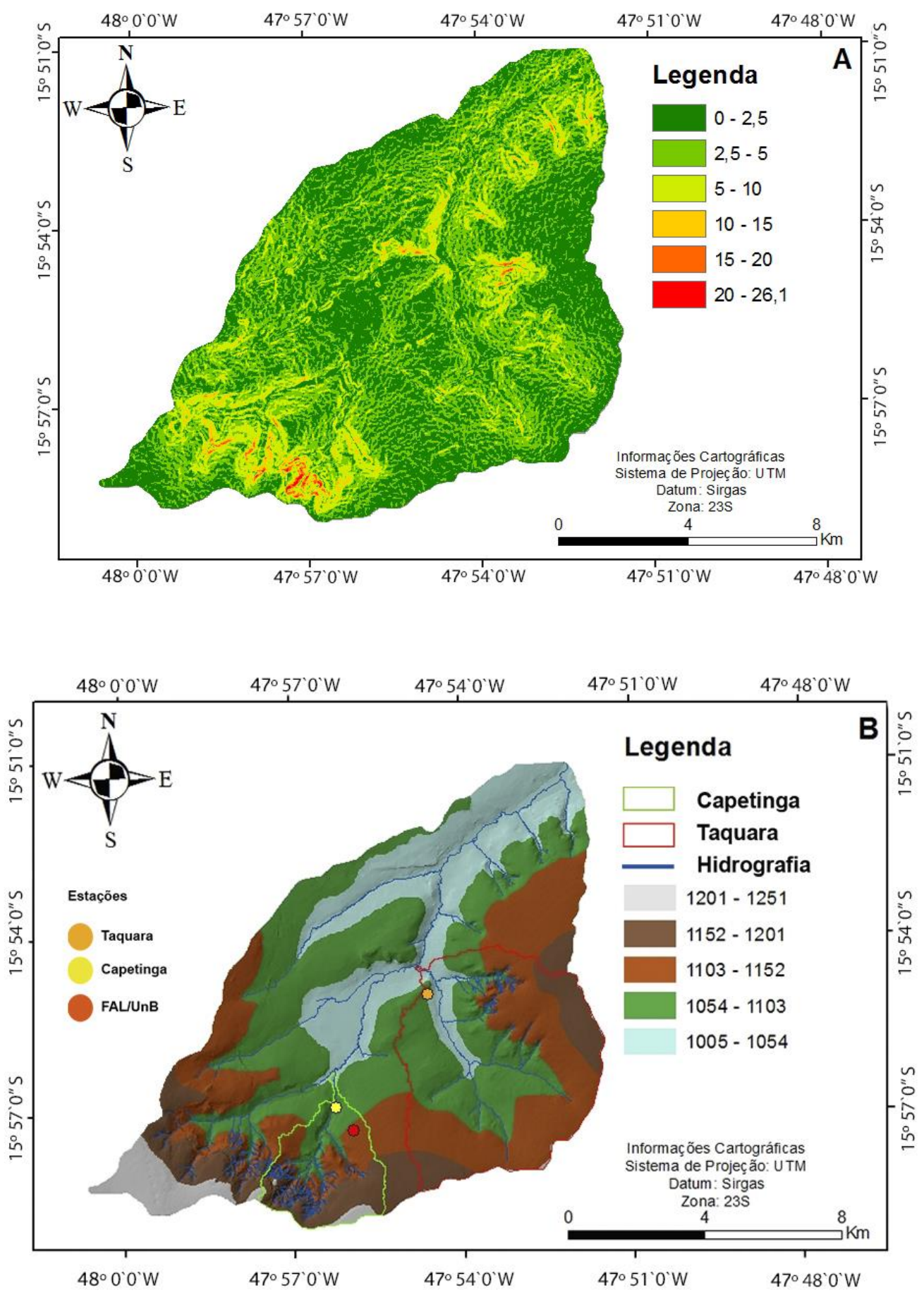

Figura 16: A - Mapa de declividade - Bacia Ribeirão do Gama. Fonte: Terracap 2010 - Escala: 1:10.000, escala vertical: 5m. B - Mapa altimétrico - Bacia Ribeirão do Gama. Fonte: Terracap 2010 - Escala: 1:10.000, escala vertical: $5 \mathrm{~m}$. 


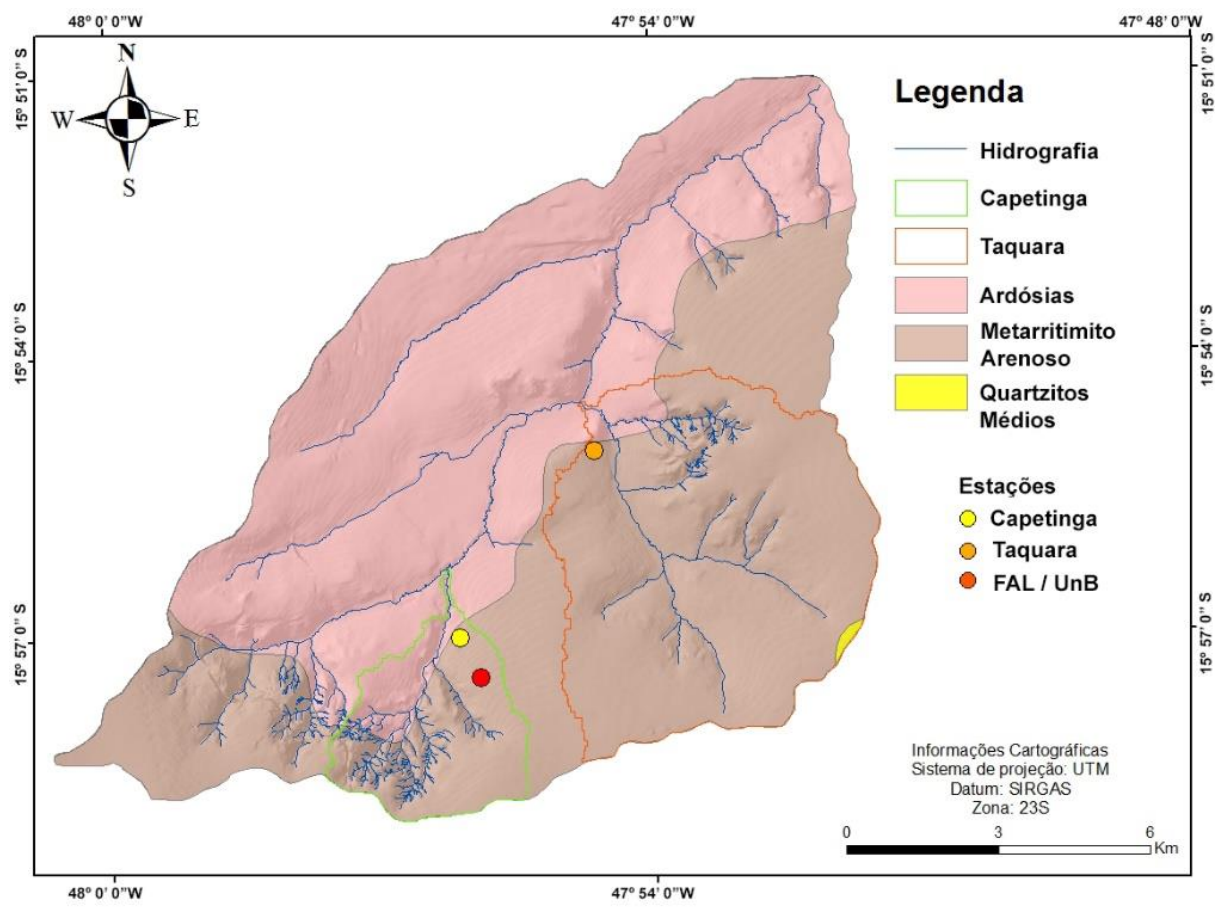

Figura 17: Mapa geológico - bacia hidrográfica do Ribeirão do Gama. Fonte: Campos, 2005 - Escala: $1: 250.000$.

A composição pedológica da bacia do Córrego Capetinga difere das outras duas, com predomínio do Cambissolo (42,06\%), seguida por Latossolo Vermelho-Amarelo (21,12\%;), Solos Hidromórficos 20,12\%), e em menor porcentagem o Latossolo Vermelho (16,77\%) (EMBRAPA, 2004) (Tabela 6 e Figura 15).

Utilizando os dados adquiridos para a bacia do Ribeirão do Gama (altimetria, declividade, dentre outros) foi possível gerar índices morfométricos para a área de estudos, a Tabela 7, ilustra as características morfométricas para as bacias estudadas. 
Tabela 7: Índices morfométricos para as bacias hidrográficas estudadas.

\begin{tabular}{|c|c|c|c|}
\hline ÍNDICE & $\begin{array}{l}\text { RIBEIRÃO } \\
\text { DO GAMA }\end{array}$ & $\begin{array}{l}\text { CÓRREGO } \\
\text { TAQUARA }\end{array}$ & $\begin{array}{c}\text { CÓRREGO } \\
\text { CAPETINGA }\end{array}$ \\
\hline Área da Bacia $\left(\mathrm{km}^{2}\right)$ & 147,81 & 38,57 & 11,47 \\
\hline Extensão da Bacia (km) & 22,6 & 9,03 & 4,89 \\
\hline $\begin{array}{c}\text { Densidade de Drenagem } \\
\left(\mathbf{K m} / \mathbf{K m}^{2}\right)\end{array}$ & 1 & 0,93 & 3,1 \\
\hline Densidade de Rios (km) & 3,36 & 3,13 & 22,23 \\
\hline $\begin{array}{l}\text { Extensão do Escoamento } \\
\text { Superficial }(\mathbf{K m})\end{array}$ & 0,5 & 0,53 & 0,16 \\
\hline $\begin{array}{c}\text { Coeficiente de Manutenção da } \\
\text { Bacia }\left(\mathrm{m}^{2} / \mathrm{m}\right)\end{array}$ & 1000 & 1075,2 & 322,5 \\
\hline Índice de Circularidade & 0,25 & 0,36 & 0,32 \\
\hline Relação Relevo (\%) & 0,08 & 0,13 & 0,2 \\
\hline Índice de Sinuosidade & 1,25 & 1,21 & 1,38 \\
\hline
\end{tabular}

A Tabela 7 evidencia que, comparando as sub-bacia, tem-se que a sub-bacia do córrego Taquara $\left(\mathbf{3 8 , 5 7} \mathbf{k m}^{2}\right)$ é maior em área do que a sub-bacia do córrego Capetinga $(4,89$ $\mathbf{k m}^{2}$ ); entretanto, mesmo sendo menor em área e extensão esta apresenta intensidade morfométrica superior à das demais bacias, como, por exemplo, maior densidade de drenagem de 3,1 $\left(\mathbf{k m} / \mathbf{k m}^{2}\right)$ contra $\mathbf{1}\left(\mathbf{k m} / \mathbf{k m}^{2}\right)$ do Ribeirão do Gama e $\mathbf{0 , 9 3}\left(\mathbf{k m} / \mathbf{k m}{ }^{2}\right)$ do córrego Taquara; maior densidade de rios $\mathbf{2 2 , 2 3}(\mathbf{k m})$ contra $3(\mathbf{k m})$ tanto para córrego Taquara quanto para o Ribeirão do Gama.

Pela (Figura 18) é observado a maior dinâmica da sub-bacia do córrego Capetinga em relação à sub-bacia do córrego Taquara pela ordenação da rede de canais, em que o córrego Capetinga possui maior quantidade de canais de $1^{\mathrm{a}}$ e $2^{\mathrm{a}}$ ordem (Figura 18).

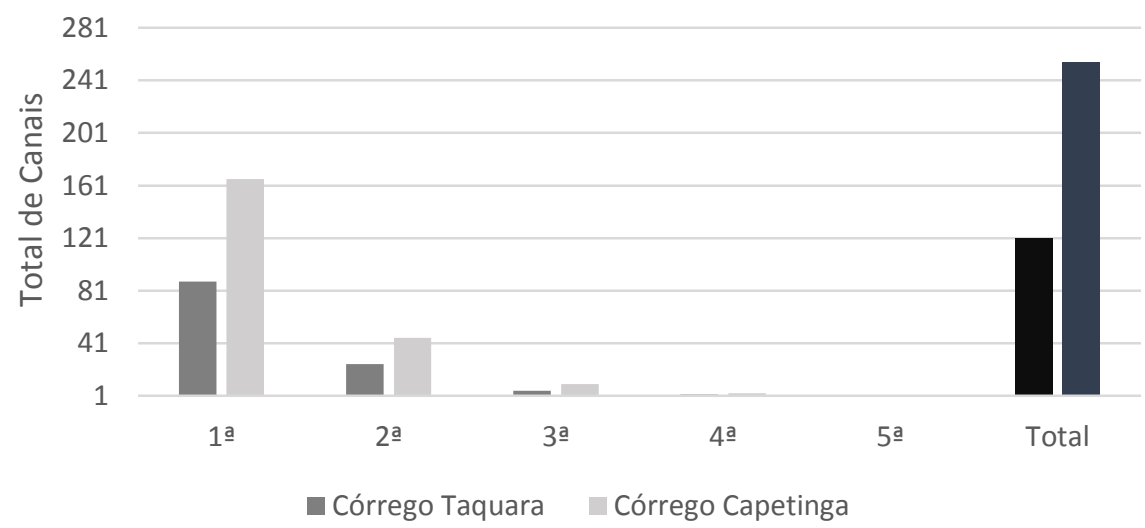

Figura 18: Quantidade e ordem dos canais - Bacia hidrográfica córrego Taquara e córrego Capetinga. 
A sub-bacia do córrego Capetinga apresenta o dobro de números de canais que a subbacia do córrego Taquara, ou seja, comporta uma área muito bem drenada (em relação as outras duas bacias) e ao mesmo tempo mais impermeável devido o predomínio de Cambissolo (Tabela 6).

\subsection{2 - Aquisição dos Insumos Geoespaciais e Análise Laboratorial das Amostras} de Sedimentos em Suspensão

Os dados de altimetria e declividade foram extraídos de base de dados do Sistema Cartográfico do Distrito Federal - SICAD, da Agência de Desenvolvimento do Distrito Federal - TERRACAP/DF, disponibilizado na escala horizontal de 1:10.000 e escala vertical de 5 metros. A base de dados de pedologia foi disponibilizada pela Empresa Brasileira de Pesquisa Agropecuária, na escala de 1:100.000 (REATTO et.al., 2004). A drenagem da bacia e as classes de uso do solo foram restituídas com base em Ortofotos da TERRACAP (2010). Os dados foram tratados em ambiente de Sistema de Informação Geográfica - SIG com os softwares ArcGis 10.2 e pelo Excel 2010.

Os dados pluviométricos foram adquiridos junto à Companhia de Saneamento Ambiental do Distrito Federal (CAESB) e com o auxílio da Agência Nacional de Águas (ANA); desta forma utilizou-se três estações pluviométricas: Área Alfa (CAESB - série temporal de 1972-2015), Fazenda Água Limpa - FAL-UnB (ANA - série temporal de 2014-2015) e Córrego Taquara (ANA - série temporal de 2014-2015).

As atividades de campo foram realizadas na bacia do Ribeirão do Gama, e nas duas sub-bacias estudadas, uma vez a cada mês; este é o intervalo limite entre uma e outra coleta de amostra de sedimento em suspensão (CARVALHO, 1994). Os métodos aplicados nas coletas de sedimento em suspensão foram: Igual Incremento Largura e Vertical Central; o primeiro consiste em dividir a seção fluviométrica em várias seções menores espaçadas em $60 \mathrm{~cm}$ uma da outra; o segundo, em coletar uma amostra de sedimento em suspensão no ponto central do rio (CARVALHO 1994; CARVALHO, 2001).

Os equipamentos utilizados nas coletas de sedimento em suspensão foram os amostradores: USDH-48 (nível d'água baixo), USDH-59 (cotas mais elevadas), e o amostrador automático ISCO 6712 (durante eventos pluviométricos no Ribeirão do Gama). Este funciona através de prévia configuração; seu disparo se deu por meio do sensor de nível que disparava a bomba de sucção sempre que este entrasse em contato com a água, até completar um ciclo de 
amostragem (24 garrafas de 1L) ou até que a água deixasse de tocar no sensor. O amostrador automático ISCO 6712 coletou total de 187 amostras de sedimento em suspensão; as coletas eram realizadas a cada 20 minutos; este operou nos últimos 4 meses da pesquisa (11/2014 a 02/2015) em níveis mais elevados de cota, pois funciona sem a necessidade de operador in situ. A tabela abaixo resume o método de coleta aplicado e a quantidade de amostras realizadas em cada bacia e sub-bacia, assim como os períodos amostrados.

Tabela 8: Demonstrativo do número de coletas, período de coleta e tipo de amostrador utilizado.

\begin{tabular}{|c|c|c|c|}
\hline \multirow[b]{2}{*}{ Tipo de Amostrador } & \multicolumn{3}{|c|}{$\begin{array}{c}\mathrm{N}^{0} \text { de Coletas e Período Amostrado por Trecho de } \\
\text { Drenagem }\end{array}$} \\
\hline & $\begin{array}{l}\text { Ribeirão do } \\
\text { Gama }\end{array}$ & $\begin{array}{l}\text { Córrego } \\
\text { Taquara }\end{array}$ & Córrego Capetinga \\
\hline USDH - 48/IIL & $\begin{array}{c}13-(01 / 2014 \mathrm{a} \\
02 / 2015)\end{array}$ & $\begin{array}{c}5-(08 / 2014 \mathrm{a} \\
01 / 2015)\end{array}$ & $\begin{array}{c}5-(08 / 2014 a \\
01 / 2015)\end{array}$ \\
\hline USDH - 48/V.C. & $\begin{array}{c}8-(01 / 2014 a \\
02 / 2015)\end{array}$ & $\begin{array}{c}5-(08 / 2014 a \\
01 / 2015)\end{array}$ & $\begin{array}{c}4-(08 / 2014 a \\
01 / 2015)\end{array}$ \\
\hline USDH - 59/ V.C. & 1 & - & - \\
\hline $\begin{array}{l}\text { Amostrado } \\
\text { Automático }\end{array}$ & $\begin{array}{c}14 \text { (eventos) - } \\
187 \text { amostras - } \\
(11 / 2014 \text { a } \\
02 / 2015 \text { não } \\
\text { sequencial) }\end{array}$ & - & - \\
\hline
\end{tabular}

A vazão instantânea foi obtida por meio do ADC (Acoustic Digital Current) em cotas mais baixas e para cotas elevadas foi utilizado o $\mathrm{ADC} \mathrm{QLinner} \mathrm{2,} \mathrm{ademais} \mathrm{de} \mathrm{réguas}$ linimétricas e equipamentos digitais para medir o nível da coluna d'água (Sensor de Nível e Radar). Em laboratório foi identificado o volume de cada amostra de sedimento em suspensão, decantada e filtrada, utilizando filtros de $47 \mu \mathrm{m}$, secados em estufa por $2 \mathrm{~h}$ em temperatura de $100^{\circ} \mathrm{C}$.

\subsection{3 - Curva-Chave Descarga Líquida e Quantidade de Sedimentos em}

\section{Suspensão}

A curva-chave da descarga líquida foi obtida pela relação nível (h) e vazão (Q), expressa na seguinte equação exponencial (Jaccon \& Cudo, 1989):

$$
\mathbf{Q}=\mathbf{a .}(\mathbf{H}-\mathbf{H o})^{\mathbf{b}}
$$

Onde a, b e Ho são parâmetros de ajuste da seção fluviométrica de interesse; H é o nível do rio $(\mathrm{m})$; Q é a vazão $\left(\mathrm{m}^{3} \cdot \mathrm{s}^{-1}\right)$, e Ho é o nível da régua para o qual a vazão é nula. 
A quantidade de sedimentos foi obtida pela relação entre a vazão (Q) e a concentração de sedimentos em suspensão (Css) apresentada por Einstein (1950) e melhorada por Colby (1957), sendo representada pela seguinte equação:

$$
\text { Qss }=0,0864 \times Q \times C s
$$

Onde Qss é a Descarga sólida total em ton.dia ${ }^{-1} ; 0,0864$, uma constante de correção de unidades (transforma as unidades de segundos para dia e gramas para toneladas); Q, a descarga líquida em $\mathrm{m}^{3} \cdot \mathrm{s}^{-1}$; e Cs, a concentração média em $\mathrm{mg} \cdot \mathrm{L}^{-1}$ ou $\mathrm{ppm}$.

\section{3 - Resultados}

\subsection{1 - Curva-Chave descarga líquida}

A equação para a curva-chave do Ribeirão Gama foi disponibilizada pela CAESB e os seus parâmetros estão listados na (Tabela 9). Os parâmetros fornecidos pela CAESB foram utilizados para elaboração da curva-chave para o período de 2014-2015 (Figura 18). Todavia a curva-chave do período de 2014-2015 apresenta superestimativa para os pontos altos, pois a maioria dos pontos amostrados foram adquiridos em cotas baixas, configurando uma curvachave para pontos de cotas baixas ou períodos de seca.

Tabela 9: Índices de ajuste da curva-chave de descarga líquida - bacias hidrográficas estudadas.

\begin{tabular}{|c|c|c|c|}
\hline $\begin{array}{c}\text { MODELO } \\
\text { EXPONENCIAL }\end{array}$ & $\begin{array}{c}\text { RIBEIRÃO } \\
\text { DO GAMA }\end{array}$ & $\begin{array}{c}\text { CÓRREGO } \\
\text { TAQUARA }\end{array}$ & $\begin{array}{c}\text { CÓRREGO } \\
\text { CAPETINGA }\end{array}$ \\
\hline $\mathbf{k}$ & 1,972 & 7,009281746 & 2,232192927 \\
\hline $\mathbf{n}$ & 1,602 & 1,60119613 & 3,2301649 \\
\hline Ho & 0,15 & 0,27 & 0,049475208 \\
\hline
\end{tabular}

A curva-chave de descarga líquida foi elaborada para as outras duas sub-bacias hidrográficas (Figuras 19 e 20), o período de amostragem destas foi de (03/01/2014 a 23/01/2015). 


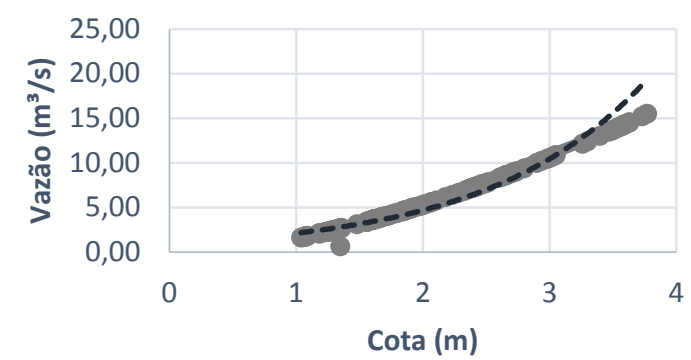

$R^{2}=0,9374$

$\longrightarrow$ VAZÃO - - - Exponencial (VAZÃO)

Figura 19: Curva-chave exponencial - vazão - Ribeirão do Gama.

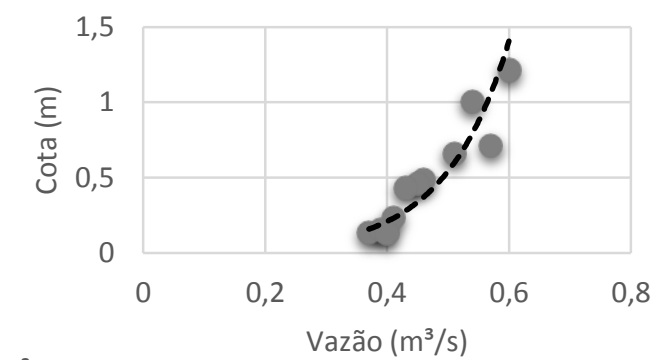

$R^{2}=0,8606$

- $\operatorname{Vazão}\left(\mathrm{m}^{3} / \mathrm{s}\right)$

----・Exponencial (Vazão $\left.\left(\mathrm{m}^{3} / \mathrm{s}\right)\right)$

Figura 20: Curva-chave exponencial - vazão córrego Taquara.

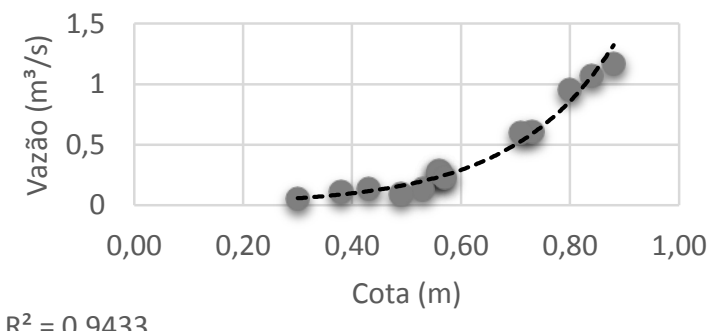

$R^{2}=0,9433$

- vazão medida $\left(\mathrm{m}^{3} / \mathrm{s}\right)$

Exponencial (vazão medida $\left.\left(\mathrm{m}^{3} / \mathrm{s}\right)\right)$

Figura 21: Curva-chave exponencial - córrego Capetinga.

Os resultados dos $\mathrm{R}^{2}$ foram bem próximos, representando boa correlação entre os dados. O valor mais baixo foi da sub-bacia do Córrego Taquara $(\mathbf{0 , 8 6 )}$ e o melhor foi do Córrego Capetinga com (0,94).

As vazões médias encontradas para o Ribeirão do Gama, córrego Taquara e córrego Capetinga foram respectivamente $2,03 \mathrm{~m}^{3} / \mathrm{s}, 0,270 \mathrm{~m}^{3} / \mathrm{s} 0,428 \mathrm{~m}^{3} / \mathrm{s}$.

\subsection{2 - Resposta pluvio-fluviométrica e sedimentar}

O comportamento pluviométrico durante o período 2014-2015 foi distinto do observado durante o período de 36 anos (1979-2015), fato que corrobora os resultados apresentados de vazão e carga sedimentar. As Figuras 23, 24 e 25 apresentam o comportamento entre os parâmetros de precipitação, vazão e carga de sedimentos. A ocorrência de eventos pluviométricos provoca o aumento da vazão em curto intervalo de tempo (Figuras 26, 27 e 28). 


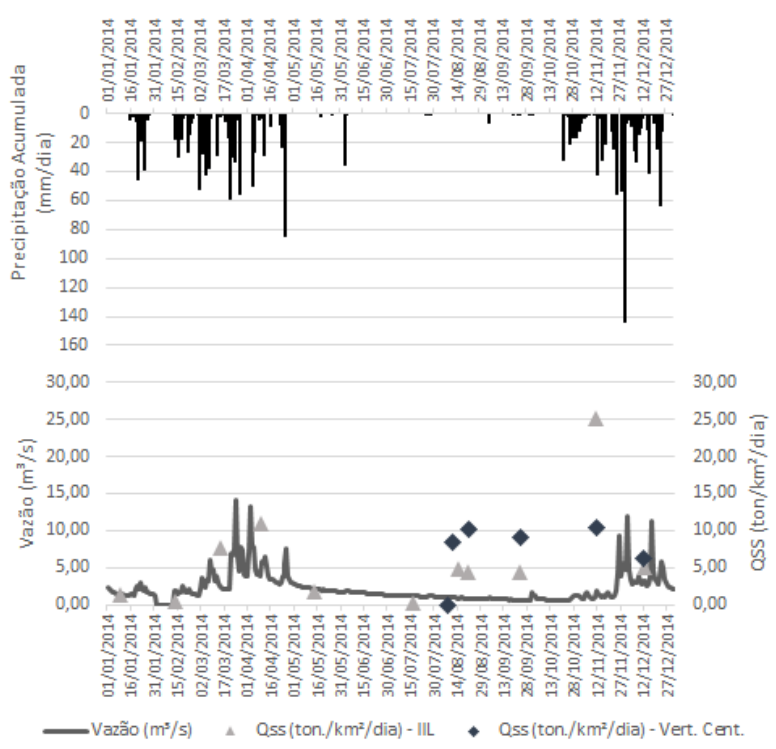

Figura 22: Precipitação (mm) - Estação pluviométrica Área Alfa x vazão $\left(\mathrm{m}^{3} / \mathrm{s}\right)$ x descarga sólida observada em suspensão (ton. $/ \mathrm{km}^{2} / \mathrm{dia}$ ) - Método Igual Incremento Largura e Vertical Central- Ribeirão do Gama.

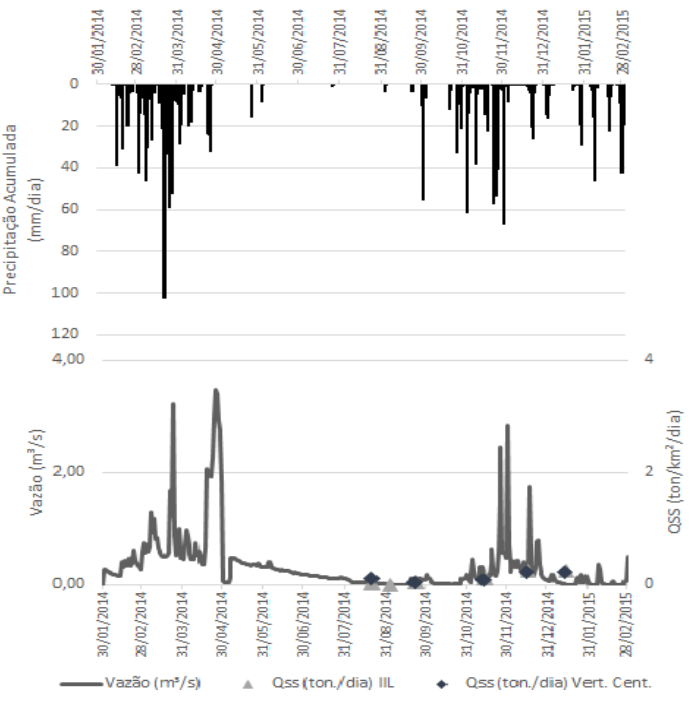

Figura 23: Precipitação (mm) Estação pluviométrica - córrego Taquara $\mathrm{x}$ vazão $\left(\mathrm{m}^{3} / \mathrm{s}\right) \mathrm{x}$ descarga sólida observada em suspensão (ton. $/ \mathrm{km}^{2} / \mathrm{dia}$ ) - Método Igual Incremento Largura e Vertical Central - córrego Taquara.

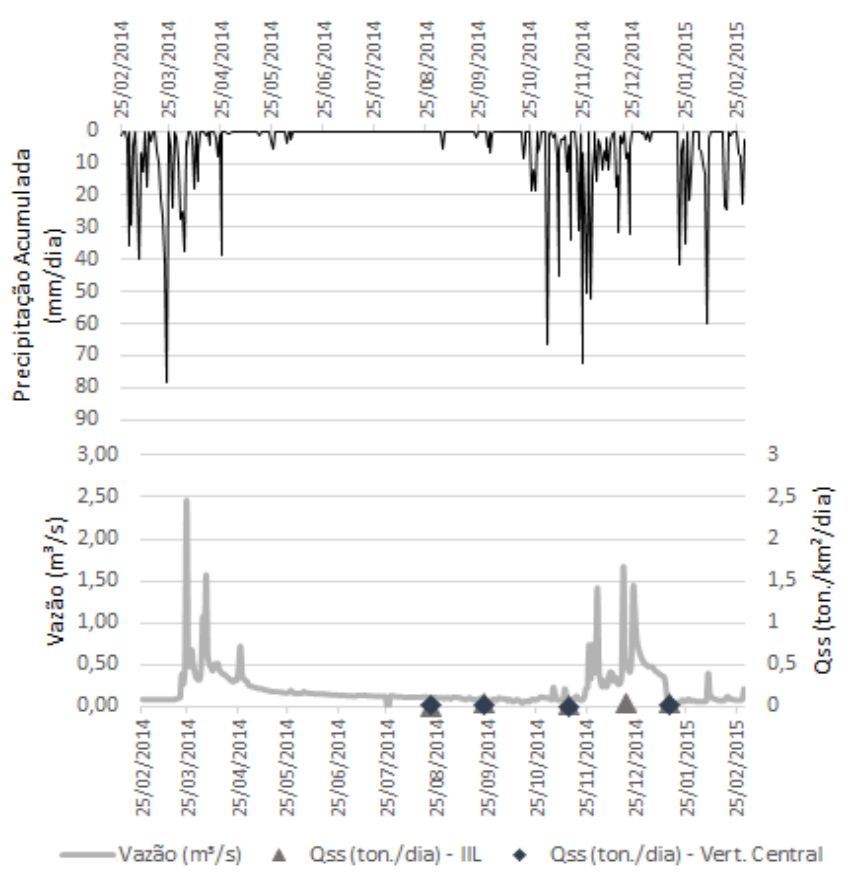

Figura 24: Precipitação (mm) Estação pluviométrica - Fal_UnB x vazão $\left(\mathrm{m}^{3} / \mathrm{s}\right)$ x descarga sólida observada em suspensão (ton. $/ \mathrm{km}^{2} / \mathrm{dia}$ ) - Método Igual Incremento Largura e Vertical Central- córrego Capetinga.

A resposta chuva $x$ vazão é basicamente imediata, quando havendo eventos pluviométricos intensos há aumento rápido da vazão nas sub-bacias. Isso se deve pelo entalhamento dos canais, vegetação incipiente nas encostas do córrego Taquara, declividade 
acentuada nas encostas do córrego Capetinga e pelo material de composição do leito dos córregos de ambos os canais, os quais são compostos por Ardósia.

O tipo de escoamento na bacia do Ribeirão do Gama segue o modelo de Hewlett \& Hibbert, onde parte do volume precipitado irá infiltrar-se dentro do solo nas partes altas da bacia, elevando o teor de umidade no perfil do solo e provocando deslocamento hídrico no sentido da vertente até emergir próximo aos canais, provocando a saturação do solo.
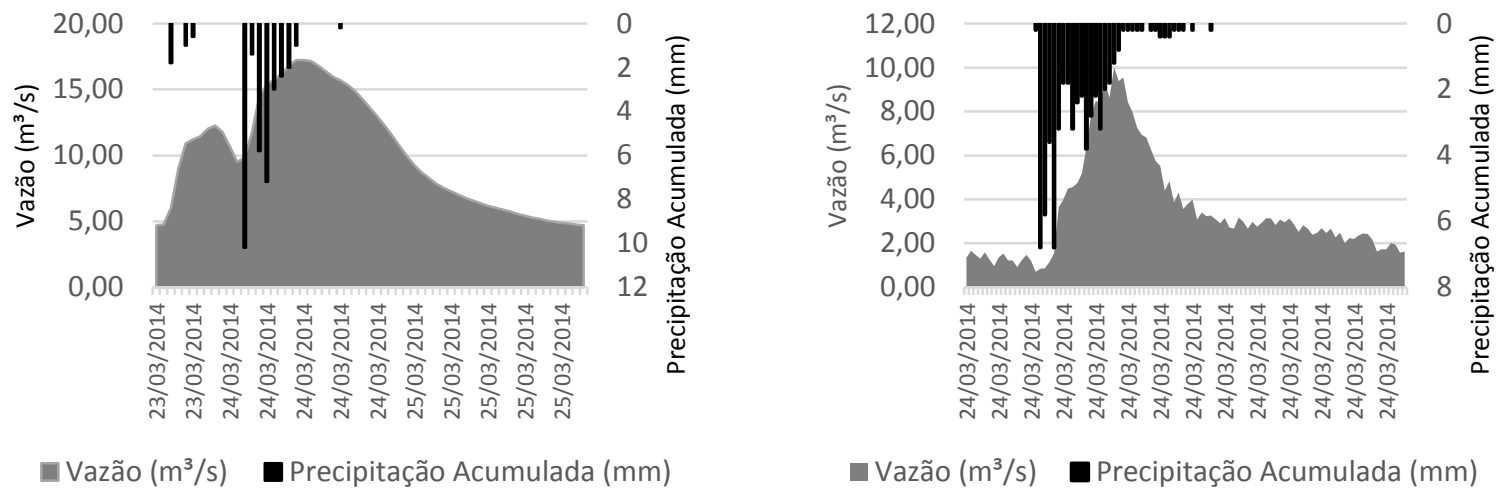

Figura 25: Curva de resposta da vazão $x$ evento Figura 26: Curva de resposta da vazão $x$ evento pluviométrico - Estação Área Alfa (23/03/2014 - 14:14 pluviométrico - Estação córrego Taquara (24/03/2014 - 26/03/2014 - 00:14 - 1h/1h) - Ribeirão do Gama. 24/03/2014 - 15min./15 min.) - córrego Taquara.

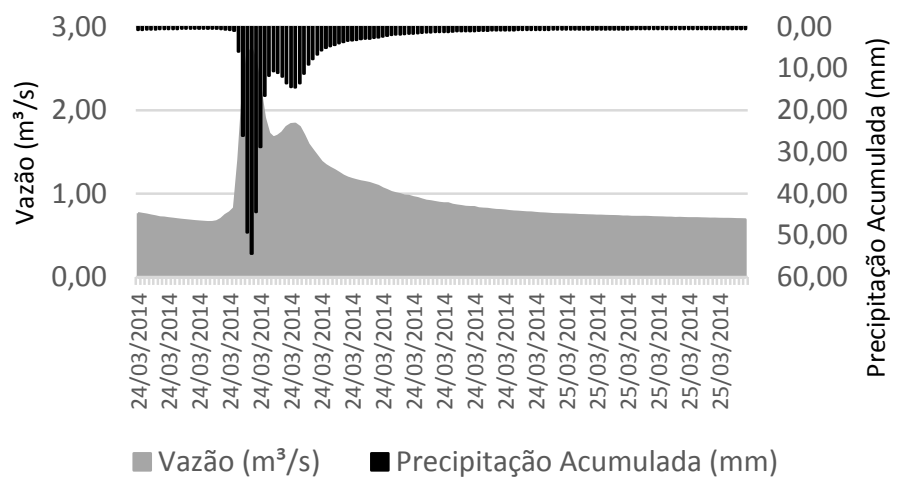

Figura 27: Curva de resposta da vazão x evento pluviométrico - Estação FAL - UnB (24/03/2014 - 25/03/2014 $15 \mathrm{~min} . / 15 \mathrm{~min}$.) - córrego Capetinga.

Das três bacias estudadas, a sub-bacia do córrego Capetinga é a que exibe resposta mais rápida (ascensão e regressão do nível fluviométrico) em relação ao fenômeno pluviométrico. Foi verificado em campo que o fluxo desta sub-bacia durante os eventos é do 
tipo turbulento e com carga sedimentar muito maior do que em baixa vazão, pois a coloração da água torna-se marrom escuro e quando o escoamento é normal; sem eventos intensos a água é límpida (Figura 26). Em oposição ao córrego Capetinga há o Ribeirão do Gama, que apresenta resposta mais lenta (Figura 24). O Ribeirão do Gama gasta um período de 24 horas para ter sua vazão alterada de $9 \mathrm{~m}^{3} / \mathrm{s}$ para $17,24 \mathrm{~m}^{3} / \mathrm{s}$ e regressar à vazão de $9 \mathrm{~m}^{3} / \mathrm{s}$, enquanto o córrego Taquara e o córrego Capetinga apresentam tempo de ascensão e retorno de aproximadamente $8 / 9$ horas conforme o evento.

O comportamento do transporte de sedimentos em suspensão mostra-se padronizado com pouca variação entre o período de seca e chuva por ambos os métodos de coleta analisados (Figuras 23 a 25). A quantidade média de sedimentos para o córrego Taquara foi de $\mathbf{0 , 1 2 5}$ (ton $\left./ \mathbf{k m}^{2} / \mathbf{d i a}\right)$; o córrego Capetinga apresentou média de $\mathbf{0 , 0 7}\left(\mathbf{t o n} / \mathbf{k m}^{2} / \mathbf{d i a}\right)$, estes resultados relacionam-se com os tipos de usos predominantes e com a vegetação local.

Pelo exposto na (Figura 22) fica claro que no corpo hídrico do Ribeirão do Gama chega uma quantidade de sedimentos em suspensão cerca de 10 vezes maior que nos córregos das sub-bacias estudadas. Essa diferença entre as cargas sedimentares em suspensão está relacionada com os usos aplicados na bacia do Ribeirão do Gama, como por exemplo, olericultura e pasto, este tipo de cultura é característica por fazer com que a o solo fique exposto ou com pouca cobertura vegetal, facilitando assim sua remoção.

Analisando os resultados oriundos do coletor automático (Figura 29) é possível observar que a quantidade medida de sedimento transportado em suspensão neste método é bastante superior àquela medida através dos métodos da vertical central e do igual incremento de largura, pois os resultados do método automático é derivado de eventos de cheia do Ribeirão do Gama, apresentando média de 444 (ton $/ \mathbf{k m}^{2} / \mathbf{d i a}$ ), máximo de 5488,67(ton $/ \mathbf{k m}^{2} / \mathbf{d i a}_{\text {) }}$ e o mínimo de $\mathbf{7 , 7 4}$ (ton/ $\left.\mathbf{k m}^{2} / \mathbf{d i a}\right)$ de sedimento em suspensão amostrado. 


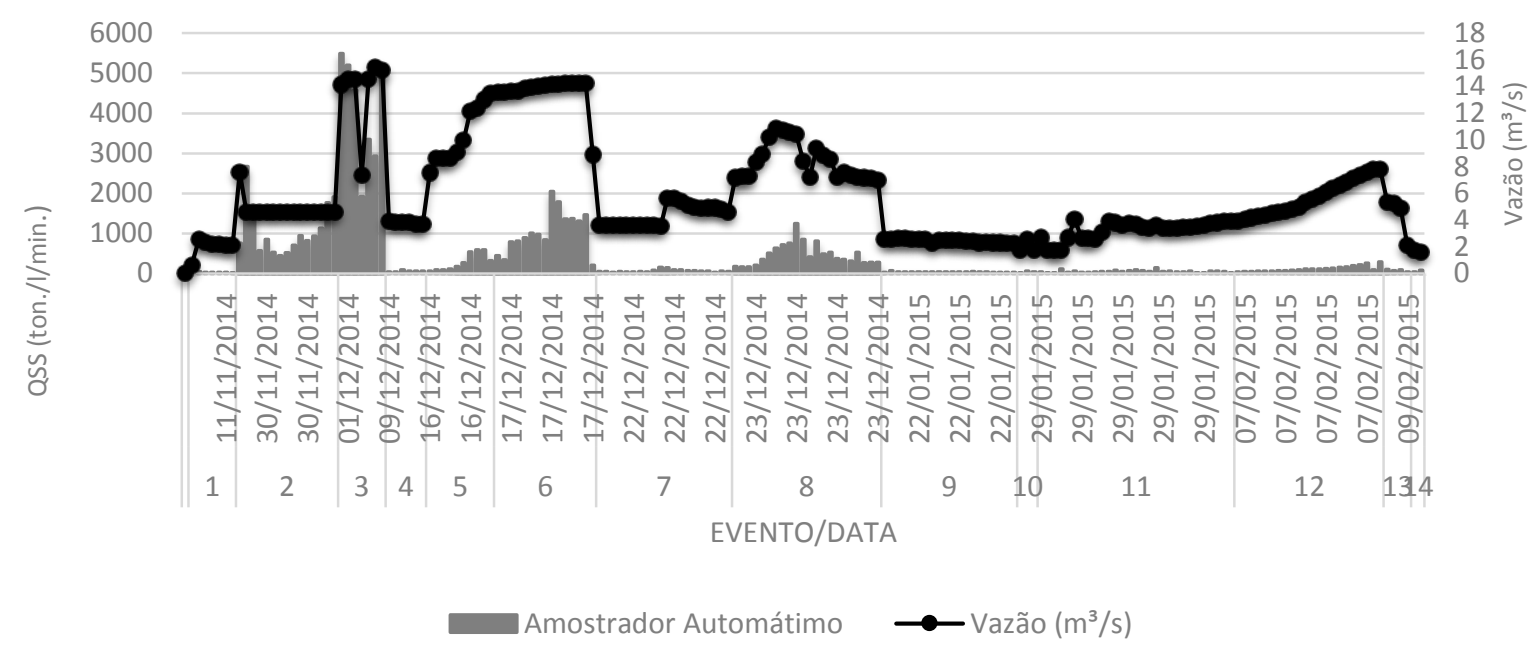

Figura 28: Resposta vazão x Qss amostrador automático.

O terceiro evento do amostrador automático ISCO 6712 apresentou a maior vazão e carga de sedimentos, seguido dos eventos 2 e 6 . Neste método a carga sedimentar e a vazão começam baixas e elevam-se à medida que o evento avança no tempo. Assim como nos outros métodos, a carga sedimentar tende a permanecer constante após algum período, podendo ser observado este comportamento nos eventos 7 e nos de 9 a 12, além de apresentar relação diretamente proporcional entre a vazão e a quantidade de carga sedimentar transportada.

A correlação ${ }^{3}$ alcançada para a bacia do Ribeirão do Gama entre a carga sedimentar dos métodos de amostragem (coletor automático e igual incremento largura) e as vazões em cada período foi satisfatória, pois, mesmo com poucas amostragens realizadas em série as correlações se aproximaram da unidade (1) (Figuras 30 e 31) - no método do IIL o $\mathbf{R}^{2}$ foi de $\mathbf{0 , 5 0}$ e no amostrador automático o $\mathbf{R}^{\mathbf{2}}$ foi de $\mathbf{0 , 6 3}$. Entretanto, é necessário dar prosseguimento à pesquisa e aumentar a série temporal de coletas de sedimentos em suspensão.

3 Para as sub-bacias não foi inserido suas correlações, pois a quantidade de dados induzia a superestimação do resultado, tendendo a erro. 


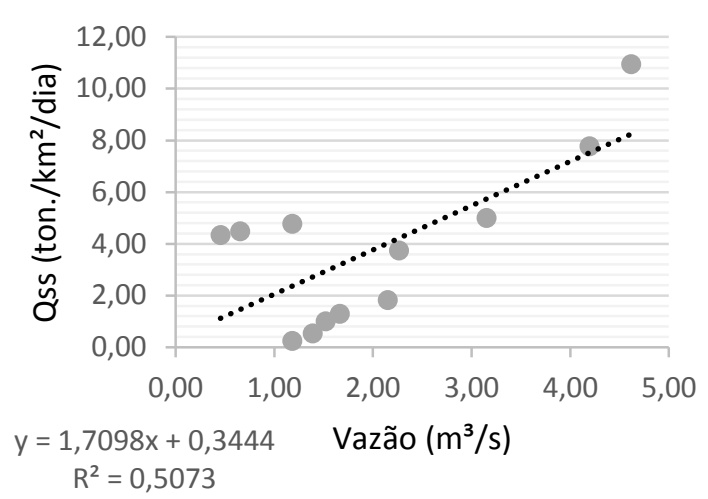

Figura 29: Correlação vazão x Qss (ton. $/ \mathrm{km}^{2} / \mathrm{dia}$ ) Método Igual Incremento Largura - Ribeirão do Gama.

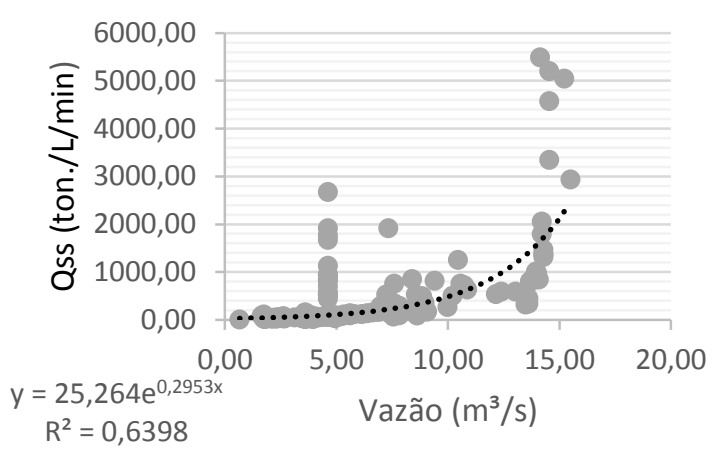

Figura 30: Correlação vazão ( $\left.\mathrm{m}^{3} / \mathrm{s}\right)$ x Qss (ton./L/min.) Método amostrador automático - Ribeirão do Gama.

\section{4 - Discussões}

Os resultados sedimentológicos encontrados para a bacia hidrográfica do Ribeirão do Gama foram interessantes, pois seus comportamentos revelam-se constantes tanto em período seco quanto após os eventos pluviométricos (Gráficos 21, 22, 23). Entretanto, por meio do amostrador automático e pelas visitas em campo foi possível verificar que a quantidade de sedimentos em suspensão para o Ribeirão do Gama eleva-se de forma considerável, variando entre 7,7 (janeiro) e 5488 (dezembro) (t./ $/ \mathrm{km}^{2} / \mathrm{dia}$ ) em relação as baixas vazões deste canal. Valores superiores a 1600 t/ha/ano são considerados altos e demonstram que a bacia tem potencial para a erosão natural (VALÉRIO FILHO, 1994 citado por SIMÕES et al., 2007).

É válido ressaltar que a constância nos resultados encontrados para a carga sedimentar em suspensão pode ser derivada do fato de que as coletas de sedimento foram realizadas em cotas baixas. Isto resultou em uma curva-chave de descarga líquida para cotas baixas e superestimativa dos pontos de cotas altas. Fragoso (2008), realizou estudos hidrossedimentológicos na bacia do Córrego do Capão Comprido, afirmou em seu trabalho que utilizou a curva-chave de sedimentos feita por Bicalho (2006) porque não foi possível coletar amostras de sedimentos em eventos de cheia. Como a bacia do Ribeirão do Gama ainda não possui estudos desse porte, é aceitável utilizar os dados auferidos, pois caracterizam-se como dados primários.

Os dados (vazão e sedimento em suspensão) em cotas altas não foram mensurados porque até o fim desta pesquisa não havia segurança para os operadores realizar as atividades de medição. A vazão nos trechos de drenagem estudados é bastante elevada em eventos de cheia e nas pontes não há estrutura de apoio para os operadores. 
É digno destacar que as respostas encontradas de chuva, vazão e sedimentos foram mínimas, principalmente na sub-bacia do córrego Capetinga, este aspecto se relaciona com a vegetação encontrada em cada bacia, exemplificando, nesta sub-bacia destaca-se uma vegetação do tipo mata-de-galeria mais densa que no córrego Taquara, esta última predomina as gramíneas e o cerradão. No trecho de drenagem Ribeirão do Gama também se destaca o tipo de vegetação mata-de-galeria. Essa característica faz com que a infiltração hídrica no solo e o escoamento sejam mais tênues do que nas localidades onde predomina as gramíneas.

Outro motivo que explica a constância no aporte de sedimentos em suspensão encontrados são as classes de usos do solo estabelecidos na bacia do Ribeirão do Gama e nas sub-bacias (córrego Taquara e córrego Capetinga), onde predominam as classes Campo, Cerrado, Olericultura e Pasto respectivamente (Tabela 5). Dias et al., (2005) vêm afirmar isso em seu trabalho realizado na bacia do Paraíba do Sul - Trecho paulista: ressaltam que os padrões de cobertura e uso do solo determinam a quantidade de sedimentos (dissolvidos ou em suspensão) nos canais de drenagem da bacia, afetando sobremaneira a qualidade da água.

O uso do solo desenvolvidos nas bacias hidrográficas apresentaram significativa importância na produção de sedimentos e no transporte de sedimentos em suspensão, no trecho de drenagem do Ribeirão do Gama foi verificado que o quantitativo sedimentar é praticamente dez vezes superior que nas sub-bacias; demonstrando este fato tem o estudo desenvolvido por Brum (2010) na bacia do córrego Sujo, localizado em Teresópolis - Rio de Janeiro, o autor afirma em sua pesquisa que mesmo a agricultura do tipo olericultura ocupando apenas $4 \%$ de toda a bacia hidrográfica, a contribuição sedimentar é extremamente alta, principalmente quando ocorre eventos intensos de chuva, pois na olericultura o solo fica mais exposto aos eventos climáticos provocando a desagregação deste.

O resultado do amostrador automático expõe esse comportamento na bacia do Ribeirão do Gama, por meio deste equipamento foi possível verificar que durante eventos de chuva intensos esta bacia, de forma geral, produz grande quantidade de sedimentos e a agricultura é uma das grandes responsáveis por este impacto, com isso é possível dizer ainda que os impactos causados por essa produção de sedimentos não são medidos durante médio a longo período de tempo, mas sim durante eventos extremos, confirmando mais uma vez a importância de pesquisas desta natureza.

Entretanto, nas sub-bacias ocorrem duas situações distintas, pois apresentam dinâmicas hidrológicas diferentes. A sub-bacia do córrego Taquara é basicamente inalterada, com morfometria suave e mais estável que a do córrego Capetinga, o que colabora para 
diminuição do escoamento superficial e consequentemente com o transporte de sedimentos para o leito dos rios (CHRISTOFOLETTI, 1981; TONELLO, 2006; JUNIOR e ANDREOLI, 2014) e a densidade de rios $(3,13 \mathrm{~km})$ e de drenagem $\left(0,93 \mathrm{~km} / \mathrm{km}^{2}\right)$ não são muito intensas (LIMA, 2008).

A sub-bacia do córrego Capetinga apresenta mais usos do solo do que a sub-bacia do córrego Taquara (olericultura com canais de irrigação e pastos) e relevo mais declivoso, que possibilitam maior velocidade de escoamento superficial e maior carreamento de sedimentos para os rios, esta sub-bacia comporta-se ainda como córrego de cabeceira que apresenta resposta bem rápida, superando a velocidade de resposta do Ribeirão do Gama em aproximadamente três vezes durante eventos de chuva. Quanto à densidade de drenagem $\left(3,1 \mathrm{~km} / \mathrm{km}^{2}\right)$ e de rios $(22,23 \mathrm{~km})$, estas são mais elevadas, explicitando que a rocha e o solo desempenham menor resistência à erosão (LIMA, 2008).

Durante a pesquisa foi inferido que, quanto maior a densidade de drenagem, maior a vazão, e que, quanto mais próxima da foz do canal principal, mais elevada ela fica. Castro e Carvalho (2009) verificaram a mesma situação em seus estudos realizados no rio Turvo no estado do Goiás. Assim, pode-se observar que a morfometria se comporta como auxiliar na produção e principalmente no transporte de sedimentos.

No desenvolver deste estudo evidenciou-se que as classes de solo interferem na velocidade de escoamento e na infiltração hídrica, pois como a sub-bacia do córrego Capetinga é composta em sua maioria pela classe de solos Cambissolo o escoamento e a velocidade de escoamento deste são superiores as outras bacias, nas quais predominam a classe LatossoloVermelho, assim, devido a este perfil de solo ser melhor desenvolvido a infiltração ocorre de forma mais intensa que no Cambissolo, o qual está bem próximo do material de origem com solo incipiente. Esses aspectos vêm se confirmar na densidade de drenagem de cada bacia, onde o córrego Capetinga possui três vezes mais drenagem que as outras duas bacias e apresenta o dobro do número de canais da sub-bacia do córrego Taquara. Estas características fazem com que o pico de vazão no córrego Capetinga seja muito rápido, enquanto o córrego Taquara e o Ribeirão do Gama apresentam respostas hídricas mais atenuadas.

A rapidez na resposta da descarga líquida também está relacionada com a estrutura geomorfológica das sub-bacias, pois ambas possuem entalhamento aprofundado do talvegue e margens estreitas. Isso caracteriza trechos relacionados com resposta de descarga líquida turbulenta e rápidas (CHORLEY, et.al., 1962; CHRISTOFOLETTI, 1981, CARVALHO, 2000). Essa rapidez representou um fator limitante para pesquisa, pois a maioria dos eventos de 
chuva ocorreram durante a madrugada e o comportamento hidrológico de escoamento também é rápido. Melo et. al. (2009) enfrentaram a mesma problemática, mas mesmo assim obtiveram ótima correlação de sedimentos em suspensão para o rio Jacu $\left(\mathrm{R}^{2} 0,96\right)$.

Para a bacia do Ribeirão do Gama foram encontradas boas correlações (Figuras 30 e 31), pois apresentaram $\mathrm{R}^{2}$ com valores entre 0,5 e 0,6 ; Walszon et al. (2005), em pesquisa sobre a análise do fluxo de sedimentos em suspensão na bacia do rio Iguaçu, para ajuste da curva aos dados medidos da vazão sólida de sedimentos em suspensão em função da vazão líquida, definiram dois critérios para a aceitação. O primeiro estabelecia que o coeficiente de determinação $\left(\mathrm{R}^{2}\right)$ deveria ser superior a 0,60 . O segundo, que a curva obtida deveria apresentar um bom ajuste visual aos dados medidos. Logo os coeficientes encontrados para o Ribeirão do Gama podem ser considerados bons, visto que o período de amostragem foi curto, a pluviometria para esse ano foi distinta e porque não há ainda estudos desta temática para a área estudada.

Ainda em relação a velocidade de escoamento no canal o Ribeirão do Gama, tem-se que ela se comporta diferente das sub-bacias: apresenta margens mais largas e trechos de espraiamento, o que torna sua resposta de vazão mais lenta do que nas sub-bacias, demorando cerca de 24 horas para ascender a um pico máximo e regressar a cotas normais (Figuras 26, 27 e 28).

Esse retardo no escoamento faz com que a lei de Stokes e o número de Reynolds atuem por mais tempo do que o normal sobre os sedimentos em suspensão, prolongando seu tempo em suspensão e em fluxo. Como cada partícula possui determinado tempo de decantação, se o escoamento é retardado, constante, turbulento e com vazão superior ao normal, as partículas finas permanecem em suspensão por mais tempo do que o normal, contribuindo para o aumento da concentração de sedimentos em suspensão caso alguma coleta seja feita neste intervalo de regressão do rio (LIMA e LUZ, 2001).

O fenômeno observado da constância da quantidade de sedimentos em suspensão ocorreu nas duas metodologias de coleta mais utilizadas (vertical central e no IIL), mas é mais visível no Ribeirão do Gama, onde a discrepância entre as metodologias foi maior, mas o comportamento entre as metodologias foi bastante semelhante; o método do vertical central teve concentração de sedimentos em suspensão superior ao do IIL (Figura 23).

Isto, ademais do fato dos sedimentos permanecerem bastante tempo em suspensão, pode estar relacionado com o fato da quantidade amostrada, pois no método do IIL coletava-se em média $1,5 \mathrm{~L}$ de amostra contra $750 \mathrm{ml}$ na vertical central. Essa quantidade maior de amostra 
pode ter provocado diluição dos sedimentos, visto que nas sub-seções de amostragem próximas às margens apresenta-se menor quantidade de sedimento em suspensão. Deve-se ressaltar ainda que a seção fluviométrica do Ribeirão do Gama é maior que as das sub-bacias, implicando em maior quantidade de amostras coletadas.

Nas sub-bacias as diferenças nos métodos amostrais não foram muito pronunciadas, pois suas seções fluviométricas são bem estreitas, medindo apenas 2,7 metros de largura, o que implica pouca variação sedimentológica entre as sub-seções de amostragem. Logo, nesse tipo de canal, os dois métodos são aceitáveis e apresentam quantidade de sedimentos em suspensão bem próximas; entretanto, o método da vertical central torna-se mais rápido e prático do ponto de vista amostral (CARVALHO, 2001; FRAGOSO 2008), dessa forma é necessário avaliar as características da bacia estudada, assim como as particularidades de cada seção fluviométrica, pois essas variáveis implicaram na metodologia aplicada nas coletas de sedimentos em suspensão.

\section{5 - Considerações Finais}

A relevância deste Trabalho é enorme, tanto do ponto de vista ambiental quanto econômico e social, pois as pequenas bacias são as tributárias das bacias maiores, ou seja, a vitalidade das bacias menores é fundamental para a manutenção dos ecossistemas maiores, em consequência disto este estudo torna-se importante.

Durante o desenvolvimento desta pesquisa foi possível verificar que monitorar pequenas bacias pode ser um trabalho surpreendente, pois elas podem apresentar comportamentos e padrões distintos dos idealizados pelos pesquisadores no início da pesquisa, exemplificando tem-se que na bacia do Ribeirão do Gama nós conseguimos visualizar padrões diferentes de transporte de sedimentos entre as sub-bacias (Taquara e Capetinga) e a bacia principal, em que as sub-bacias apresentaram respostas bem mais rápidas que o Ribeirão do Gama devido a estrutura geomorfológica predominante em cada bacia, devido aos usos do solo, aos tipos de solos em cada uma e pela vegetação.

Conclui-se ainda que a olericultura desenvolvida na bacia do Ribeirão do Gama, mesmo abrangendo pequena área da bacia, contribui de forma efetiva para a alta concentração de sedimentos em suspensão no canal principal durante intensos eventos pluviométricos, pois constatou-se que durante estes eventos a concentração do material em suspensão eleva-se de forma intensa nas proximidades de sua foz. 
A realidade desta bacia juntamente com a realidade das outras sub-bacias do Lago Paranoá vem contribuir para o comprometimento da sustentabilidade do ecossistema do Lago, visto que esse ambiente lacustre é lêntico, ou seja, todo sedimento que chega ao lago é retido por ele, caso a quantidade de entrada de sedimentos seja superior a sua capacidade de absorção do material chegado inicia-se assim o processo de eutrofização deste, o que prejudica toda a estrutura desenvolvida a partir dele, tal como, geração de energia, lazer e esportes aquáticos, futuras instalações da adutora que será responsável por captação de água para parte da população do Distrito Federal e a manutenção das espécies que vivem no Lago e em suas redondezas.

Desta forma, afirma-se que este estudo de monitoramento da quantidade de transporte de sedimentos em suspensão é extremamente importante para a manutenção da qualidade da água, diminuição dos gatos com manutenção das hidrelétricas devido aos problemas causados pelo excesso de sedimentos, para preservação dos ecossistemas desenvolvidos, para a qualidade de vida da população dependente dos recursos hídricos, dentre outros. Por fim, é relevante enfatizar que é necessário continuar as pesquisas de monitoramento do transporte de sedimentos na bacia do Ribeirão do Gama e suas sub-bacias, a fim de potencializar os dados iniciais adquiridos nesta pesquisa.

\section{Agradecimentos}

Esta pesquisa teve apoio financeiro e material da CAPES, PTHAR-UnB - Programa de Pós-Graduação em Tecnologia Ambiental e Recursos Hídricos do Departamento de Engenharia Civil e Ambiental da Universidade de Brasília, Departamento de Pós-Graduação em Geografia-UnB e Instituto de Geociência-UnB, além da concessão de aparelhos de meteorológicos e apoio em campo da Agência Nacional de Aguas - ANA, da Companhia de Saneamento Ambiental do Distrito Federal - CAESB e da Fazenda Experimental Água Limpa da Universidade de Brasília - FAL-UnB.

\section{Referências Bibliográficas}

BRANCO, N. "Avaliação da produção de sedimentos de eventos chuvosos em uma pequena bacia hidrográfica rural de encosta". Dissertação de mestrado em Engenharia Agrícola - Área de concentração em Irrigação e Drenagem. Universidade Federal de Santa Maria, S, 1998. 
BICALHO, C. C. "Estudo do transporte de sedimentos em suspensão na bacia do rio Descoberto". Dissertação de Mestrado. Faculdade de Tecnologia. Universidade de Brasília, DF. 2006.

BRUM, L. B. "O uso da água pela agricultura irrigada na Região Serrana do Rio de Janeiro: Bacia do Córrego Sujo - Teresópolis”. Dissertação de Mestrado em Geografia Instituto de Geociências, Universidade Federal do Rio de Janeiro, RJ, 2010.

CAMPOS, J. E.G. "Hidrogeologia do Distrito Federal: bases para a gestão dos recursos hídricos subterrâneos”. Revista Brasileira de Geociências, v. 34, 2005.

CARVALHO, A. P. F. de, et. al.. "Desenvolvimento de metodologia em SIG para zoneamento ecológico: estudo de caso da bacia do Ribeirão do Gama - DF". Embrapa Cerrados, Planaltina, DF, 2001.

CARVALHO, N. de O. "Hidrossedimentologia prática”. CPRM, ELETROBRÁS. Rio de Janeiro, RJ, 1994.

CASTRO, S. B.; CARVALHO, T. M. "Análise morfométrica e geomorfologia da bacia hidrográfica do rio Turvo - GO, através de técnicas de sensoriamento remoto e geoprocessamento". Revista Scientia Plena, v. 5, 2009.

CODEPLAN - Companhia de Planejamento do Distrito Federal. “Atlas do Distrito Federal". $1^{\text {a }}$ ed., Brasília - GDF, 1984.

CHORLEY, R. J. “Geomorphology and General Systems Theory”. US. Geological Survey Professional paper, v. 500-B, 1962.

CHRISTOFOLETTI, A. “Geomorfologia”. São Paulo: Edgard Blucher, 1981.

FRAGOSO, M. M. A. (2008). "Estudo hidrológico e de transporte de sedimentos em uma bacia do bioma Cerrado: bacia do córrego do Capão Comprido," Universidade de Brasília, $\mathrm{DF}$.

FREITAS-SILVA, F. H. CAMPOS, J. E. G. “Geologia do Distrito Federal”. In: Inventário Hidrogeológico e dos Recursos Hídricos Superficiais do Distrito Federal. GDF: 1998.

FRANZA, C.; MAKESCHINA F., WEIB, H.; LORZC C. "Sediments in urban river basins: Identification of sediment sources within the Lago Paranoá catchment, Brasilia DF, Brazil - using the fingerprint approach". Science of The Total Environment. V.466-467, 2014. JUNIOR J. J.; ANDREOLI C. V. "Uso de dados climáticos e hidrológicos como subsídio na determinação do regime de fluxo de canais de drenagem". Revista Brasileira de Geomorfologia, SP, v. 16, 2014. 
Reatto, A., Martins, É. D. S., Farias, M. F. R., Silva, A. V. D., \& Carvalho Júnior, O. A. D. "Mapa pedológico digital-SIG atualizado do Distrito Federal, escala 1: 100.000 e uma síntese do texto explicativo". Planaltina: Embrapa Cerrados, 2004.

SANTOS, I. D., FILL, H. D., SUGAI, M. R. V. B., BUBA, H. KISHI, R. T, MARONE, E. e LAUTERT, L. F. "Hidrometria Aplicada”. Instituto de Tecnologia para o Desenvolvimento, Curitiba, 2001.

LEOPOLD, L. B.; Wolman, M. G.; Miller, J. P. "Fluvial process in geomorphology”. Library of Congress. 1995.

LIMA, W.P. "Hidrologia florestal aplicada ao manejo de bacias hidrográficas". USP. Piracicaba. 2008.

LIMA, R. M. F.; LUZ, J. A. M. da. “Análise granulométrica por técnicas que se baseiam na sedimentação gravitacional: Lei de Stokes”. Rem: Rev. Esc. Minas [online]. 2001, v. 54, nº. 2, pp. 155-159. ISSN 1807-0353. Disponível em: <http://dx.doi.org/10.1590/S037044672001000200014>.

MARTINS, S. E. de. "Evolução geomorfológica do Distrito Federal”. Planaltina, Embrapa Cerrados, Brasília, DF, 2004.

MELO, R. O.; CANTALICE, J. R. B.; ARAÚJO, A. M.; CUNHA FILHO, M. "Produccão de sedimento suspenso de uma típica bacia hidrográfica semi-árida”. VII Encontro Nacional de Engenharia de Sedimentos. Mato Grosso do Sul, 2009.

SIMÕES, S. J. C; BERNADES, G. P.; NUNES, C. M. F.; MARCH, T. C. "Variabilidade espacial do potencial de erosão e seus efeitos na sedimentação de um pequeno reservatório — A bacia dos Mottas, Sudeste do Brasil”. Revista Brasileira de Recursos Hídricos. v. 12 nº. 3. 2007.

STRAHLER, A.N. "Quantitative analysis of watershed geomorphology". New Halen: Transactions: American Geophysical Union, 1957.

TONELLO, K. C. et. al. "Morfometria da bacia hidrográfica da cachoeira das Pombas, Guanhães - MG”. Revista Árvore, Viçosa-MG, v. 30, nº 5, 2006.

WALZSON, T.A.L.; LIMA, J.E.F.W.; VIEIRA, M. R.; DIAS, F. S. "Análise do fluxo de sedimento em suspensão na bacia do rio Iguaçu”. In anais do XVI Simpósio Brasileiro de Recursos Hídricos. João Pessoa, PB. 2005. Disponível em: < http://tede.unioeste.br/tede//tde_arquivos/1/TDE-2008-01-30T132730Z167/Publico/Kayla\%20Walquiria\%20Garmus\%20Poletto.pdf $>$. Acesso 12 de out. de 2015. 


\section{6 - Conclusão}

Conclui-se que nas sub-bacias os materiais encontrados transportados em suspensão, em sua maioria, são do tipo finos (argila e silte), o que facilita a manutenção destes em suspensão tanto no fluxo laminar quanto no turbulento. No Ribeirão do Gama, ademais destes materiais também foi observada uma elevada concentração de matéria orgânica em suspensão.

Todo esse material transportado pelas sub-bacias e pelo Ribeirão do Gama fluem em direção ao Lago Paranoá, que é uma importante estrutura geográfica para o Distrito Federal, sendo caracterizado como fonte de lazer, gerador de energia elétrica e potencializador da umidade relativa do ar (ao menos para as localidades limítrofes às margens do Lago, pois existe o fenômeno da advecção que retira o ar úmido da superfície e o leva pra longe e ao longo de seu trajeto o ar perde umidade por atrito com o solo), dentre outras características.

Estas funções do Lago podem ser comprometidas a longo prazo, pois devido à ocupação urbana desenfreada e desordenada das bacias supridoras do Lago, este vem sendo assoreado, ocorrendo perda de sua área molhada. Este fato pode ser comprovado por meio de estudos desenvolvidos, tal como em Franza et al. (2014) o qual ressalta em seu estudo que a principal fonte de sedimentos em suspensão são as sub-bacias do Lago Paranoá, principalmente as mais urbanizadas; destaca ainda que a principal contribuinte é a sub-bacia do Riacho Fundo, próxima da bacia do Ribeirão do Gama.

Esta situação é preocupante, visto que, conforme esses materiais chegam ao lago, diminui-se o volume útil para geração de energia elétrica, água para diluição do esgoto das estações de tratamento, para o lazer, para o futuro abastecimento hídrico para a população do DF, provocando mau cheiro, perda de área molhada e, principalmente, desestabilização do ecossistema do lago, que fica mais instável a cada ano. Sem dizer que essas situações aumentam os custos das obras e manutenção da adutora que se deseja instalar no Lago Paranoá e, por haver menos água para diluir os sedimentos, os custos de manutenção da hidrelétrica já instalada. Ademais há aumento da turbidez e concentração de substâncias tóxicas carreadas junto com os sedimentos, tal como agrotóxicos e fertilizantes, dentre outros malefícios.

A forma mais usual de prevenir esses riscos é o monitoramento de todas as sub-bacias do Lago Paranoá, assim como das sub-bacias destas sub-bacias mantenedoras do Lago. Os meios para isso podem ser: (1) coletas manuais in situ tanto em baixa vazão quanto em alta, 
com frequência superior a uma vez por mês; (2) amostradores automáticos; (3) sensores de turbidez; (4) Veículo Aéreo não Tripulado (VANT) com sensores de medição da carga sedimentar em suspensão - este oferece a vantagem de coletar a informação sem riscos para os operadores, atingir locais de difícil acesso, principalmente em eventos de cheia; e, como essas bacias não são muito extensas, eles são capazes de sobrevoá-las durante e após os eventos de cheia, permitindo com isso obter informações mais completas.

Essa pesquisa de monitoramento é importante para prevenir desastres no meio hídrico, controlar a qualidade da água e sua disponibilidade para seus diversos fins. Isso é válido para todo tipo de bacia, seja ela de pequeno ou de grande porte. Dessa forma, este estudo buscou demonstrar a importância do monitoramento permanente de pequenas bacias, com vistas a manter a qualidade hídrica e evitar a perda de sua disponibilidade, já que os desastres envolvendo este recurso natural comprometem toda a cadeia social e econômica. Exemplificando, tem-se o desastre do rompimento das barragens de rejeito mineral no município de Mariana no estado de Minas Gerais que comprometeu todo o sistema hídrico e natural do Rio Doce em novembro de 2015. Destarte percebe-se que esse sistema necessita de toda atenção, pois é bastante sensível às alterações em sua volta e sua recuperação é extremamente cara e demorada.

Ademais conclui-se que o monitoramento hidrossedimentológico nas estações pluviofluviométrica durante o período de um ano apresentaram baixa contribuição de sedimentos em suspensão para o Lago Paranoá em período de seca. Entretanto, quando ocorrem eventos pluviométricos intensos essa quantidade de sedimento em suspensão varia intensamente, sendo uma das causas desse aumento sedimentológico a agricultura desenvolvida na bacia do Ribeirão do Gama, que é a olericultura, a qual deixa o solo exposto, provocando mais facilmente sua desagregação. Por fim, recomenda-se continuar o monitoramento do Ribeirão do Gama, a fim de fortalecer os dados adquiridos nesta pesquisa, pois para dar contribuições mais robustas são necessários pelo menos dez anos de pesquisas. 


\section{Referências Bibliográficas}

Agência Nacional de Águas, Superintendência de Gestão da Rede Hidrometeorológica. Especificações Técnicas - Plataformas de Coletas de Dados - PCDs. ANA, SGH, Brasília, DF, 2011.

ANTONELLI, V.; TOMAZ, E. L. Caracterização do meio físico da bacia do arroio Boa Vista - Guamiranga, PR. Universidade Federal de Uberlândia. Revista Caminhos de Geografia. $\mathrm{n}^{\circ}$ .20. 2007. Disponível em: <http://www.ig.ufu.br/revista/caminhos.html $>$. Acesso em 25 de junho de 2015.

ANTONIAZZI, L.B. Oferta de serviços ambientais na agricultura. Dissertação de Mestrado em Agricultura, Universidade de São Paulo, SP, 2008.

BELliSANO, T. B.; PAIVA, J. B. D.. Avaliação da produção de sedimentos em eventos chuvosos em uma pequena bacia hidrográfica semi-urbana de Encosta. Revista Brasileira de Recursos Hídricos. v. 12. 2007.

BICALHO, C. C. Estudo do transporte de sedimentos em suspensão na bacia do rio Descoberto. Dissertação de Mestrado. Faculdade de Tecnologia. Universidade de Brasília. 2006.

BRANCO, N. Avaliação da produção de sedimentos de eventos chuvosos em uma pequena bacia hidrográfica rural de encosta. Dissertação de mestrado em Engenharia Agrícola. Universidade Federal de Santa Maria, RS, 1998.

BROOKS, K.N.; P.F. FFOLLIOT; H.M. GREGERSEN; J.L. THAMES, 1991.Hydrology and the Management of Watersheds. Iowa State University Press. 391p.

BRUM, L. B. O uso da água pela agricultura irrigada na região serrana do Rio de Janeiro: Bacia do córrego Sujo - Teresópolis. Dissertação de Mestrado em Geografia - Instituto de Geociências, Universidade Federal do Rio de Janeiro, RJ, 2010.

BRUSA, C. L.; CLARKE, T. R. Erros envolvidos na estimativa da vazão máxima utilizando curva-chave. Caso de estudo: Bacia do Rio Ibicuí, RS. Instituto de Pesquisas Hidráulicas, Universidade Federal do Rio Grande do Sul. RBRH - Revista Brasileira de Recursos Hídricos v. 4 no. 3, 1999.

CAMPOS, J. E.G. Hidrogeologia do Distrito Federal: bases para a gestão dos recursos hídricos subterrâneos. Revista Brasileira de Geociências, v. 34, 2005.

CARMO, M. S. Geoquímica de águas e sedimentos de correntes da bacia hidrográfica do rio Descoberto - Brasília - DF. Dissertação de Mestrado. Universidade de Brasília. Instituto de Geociências. 2001.

CARVAlHO, A. P. F. de, CARVAlHO, O. A. de CARVAlHO JR.; LEITE, L.; GUIMARÃES, R. F. \& MARTINS, E. de S. Desenvolvimento de metodologia em SIG para zoneamento ecológico: estudo de caso da Bacia do Ribeirão do Gama - DF. Embrapa Cerrados, Planaltina, DF, 2001. 
CARVALHO, F. H. Uso do modelo SWAT na estimativa da vazão e da produção de sedimentos em bacia agrícola do Cerrado brasileiro. Dissertação de Mestrado em Agronomia e Medicina Veterinária. Universidade de Brasília, 2014.

CARVALHO, I. C. D. H. Implicações socioambientais decorrentes do processo de urbanização da regional administrativa de Santa Maria (DF). Dissertação de Mestrado em Geografia. Universidade de Brasília, 2012.

CARVALHO, N. de O. Hidrossedimentologia Prática. CPRM, ELETROBRÁS. Rio de Janeiro, RJ, 1994.

CARVALHO, N.O.; FILIZOLA JÚNIOR, N.P.; SANTOS, P.M.C.; LIMA, J.E.F.W. Guia de práticas sedimentométricas. ANEEL. Brasília, DF, 2000.

CASSOL, E. A.; ELTZ, F. L. F.; MARTINS, D.; LEMOS, A. M.; LIMA, V. S.; BUENO, A. C. Erosividade, Padrões hidrológicos, período de retorno e probabilidade de ocorrência das chuvas em São Borja, RS. Revista Brasileira Ciência do Solo, v.32, 2008.

CASTRO, S. B.; CARVAlHO, T. M. Análise Morfométrica e Geomorfologia da Bacia Hidrográfica do rio Turvo - GO, Através de técnicas de sensoriamento remoto e geoprocessamento. Revista Scientia Plena, v. 5, 2009.

CHELLA, R.; FERNANDES, C. S.; FERMIANO, G. A.; FILL, H. D.. Avaliação do transporte de sedimentos no rio Barigui. Revista Brasileira de Recursos Hídricos. v. 10. 2005.

CHEVALLIER, P.; PLANCHON, O. Hydrological Processes in a Small Humid Savanna Basin (Ivory Coast). Journal of Hydrology, 1993.

CHEVAlliER, P. Aquisição e processamento de dados. Hidrologia - Ciência e Aplicação, C. E. M. Tucci, ed., Editora da UFRGS / ABRH, Porto Alegre, 2004.

CHORLEY, R. J. Geomorphology and General Systems Theory US Geological Survey Professional paper, v. 500-B, 1962.

CHOW, V.T., MAIDMENT, D.; MAYS, L. W. Applied Hydrology. McGraw Hill. 1988.

CHRISTOPHERSON, R. W. Geossistema: Introdução a Geografia Física. Prentice Hall. 2012.

CHRISTOFOLETTI, A. Geomorfologia. São Paulo: Edgard Blucher, 1981.

CAESB - Companhia de Saneamento Ambiental do Distrito Federal. Projeto do Sistema de Abastecimento de Água com Captação no Lago Paranoá. Distrito Federal. Disponível em: $<$ http://www.caesb.df.gov.br/296-audiencia-publica-do-sistema-de-abastecimento-de-aguado-lago-paranoa.html $>$. Acesso em: 30 de junho de 2015.

COELHO NETTO, A.L; GUERRA, A. J. T; CUNHA, S. B. Geomorfologia: uma atualização de bases e conceitos. In: COELHO NETTO, A.L. (org). Hidrologia de encostas da interface com a geomorfologia. Rio de Janeiro: Bertrand Brasil. 1994. 
CODEPLAN - Companhia de Planejamento do Distrito Federal. Atlas do Distrito Federal. $1^{\text {a }}$ ed., Brasília - GDF, 1984.

DUNNE, T. Runoff production in a humid area. Agricultural Research Service United States Departamend of Agriculture 1943.

EDWARDS, T. K.; GLYSSON, G. D. Field methods for measurement of fluvial sediment. United States of Geological Survey. Virginia, 1999.

Empresa Brasileira de Pesquisa Agropecuária - EMBRAPA. Levantamento de reconhecimento dos solos do Distrito Federal, Boletim Técnico, 2004.

FERRANTE, J. E. T. RANCAN, L.; NETTO, P. B. Hidrografia. In: Olhares sobre o Lago Paranoá. Brasília. Secretaria do Meio Ambiente e Recursos Hídricos. 2001.

FERREIRA, R. S. Estudo dos controles morfométricos a feições erosivas na bacia hidrográfica do Ribeirão da Contagem/DF. Monografia em Geografia. Universidade de Brasília. 2013.

FILL, H. D.; SANTOS, I. Estimativa de concentração de sedimentos em suspensão através da profundidade de Sechi. In: V Simpósio de Hidráulica e Recursos Hídricos dos Países de Língua Oficial Portuguesa, 2001, Aracajú.

FLORENZANO, G. T. (org.). Geomorfologia: conceitos e tecnologias atuais. São Paulo: Oficina de textos, 2008.

FREITAS-SILVA, F. H. CAMPOS, J. E. G. Geologia do Distrito Federal. In: Inventário Hidrogeológico e dos Recursos Hídricos Superficiais do Distrito Federal. GDF: 1998.

GRAF, W. Hydraulics of sediment transport, Mc Graw Hill, New York, 1971.

GUERRA, A. J. T. e CUNHA, S. B. (org.). Geomorfologia: uma atualização de bases e conceitos. Rio de Janeiro: Bertrand Brasil. 1984.

GUIMARÃES, M. R. W. Estudo dos processos de hidrossedimentologia do exutório do Riacho Fundo no Lago Paranoá, Distrito Federal. Dissertação de mestrado em Planejamento e Gestão Ambiental. Universidade Católica de Brasília, Brasília, DF, 2011.

GOERL R.F.; KOBIYAMA M.; SANTOS I. Hidrogeomorfologia: Princípios, conceitos, processos e aplicações. In: Revista Brasileira de Geomorfologia, v.13, nº.2, 2012

GUY, H. P. Fluvial sediment concepts. U. S. Government. Printing Oficce, Washington, 1970, $55 \mathrm{p}$.

HACK, J.T. Interpretation of erosional topography in humid-temperate regions. America Journal. Science, New Haven, Conn. v. 258-A, 1960.

HICKIN, E. J. Sediment transport. In: River hydraulics and channel form. Universidade da Califórnia. Wiley, 1995.

JACON, G.; CUDO, K.J. Curva-chave: análise e traçado. Brasília: DNAEE, 1989. 
JUNIOR J. J.; ANDREOLI C. V. Uso de dados climáticos e hidrológicos como subsídio na determinação do regime de fluxo de canais de drenagem. Revista Brasileira de Geomorfologia, São Paulo, v.16, 2014.

LENZI, M. A., L. MAO, F. Effective discharge for sediment transport in a mountain river: Computational approaches and geomorphic effectiveness. Journal of Hydrology. 2005.

LEOPOLD, L. B.; Wolman, M. G.; Miller, J. P. Fluvial process in geomorphology. Library of Congress. 1995.

LIMA, R. M. F.; LUZ, J. A. M. da. Análise granulométrica por técnicas que se baseiam na sedimentação gravitacional: Lei de Stokes. Rem: Rev. Esc. Minas [online]. 2001, v.54, nº 2 , pp. 155-159. ISSN 1807-0353. Disponível em: <http://dx.doi.org/10.1590/S037044672001000200014>.

LIMA, W.P. Hidrologia florestal aplicada ao manejo de bacias hidrográficas. USP. Piracicaba. 2008 .

LINSLEY, R.K. Jr. et al. Hydrology for Engineers. 2a Ed. New York: McGraw-Hill, 1975.

LOPES, G. R., Távora, B. E. Santos, R. M. \& Koide, S. Estudo sobre correlação entre turbidez e sólidos em suspensão para estimativa da vazão sólida em uma pequena bacia. Anais do XVIII Simpósio de Recursos Hídricos, Campo Grande, MS, 2009.

LOPES, H. N.; KOBIYAMA, M. \& SANTOS, I. Relação entre concentração de sedimentos em suspensão e vazão em microbacias experimentais na região norte do estado de Santa Catarina, Brasil. Simpósio Brasileiro de Recursos Hídricos, 2007.

MARTINS, S. E. de. Evolução geomorfológica do Distrito Federal. Planaltina, Embrapa Cerrados, Brasília, DF, 2004.

MARTINS, E. S; R. A.; CARVALHO JÚNIOR, O. A. E; GUIMARÃES, R. F. Ecologia de Paisagem: Conceitos e aplicações potenciais no Brasil. Documentos Técnicos. Planaltina, Embrapa Cerrados. 2004.

MAST, A. M.; TURK, J. T. Environmental characteristics and water quality of hydrologic benchmark network station in the Midwesterm United States, 1963-95. U. S. Geological Survey circular: 1173 B, 1999.

MENDONÇA, P. R. Características hidrogeomorfológicas das bacias hidrográficas dos rios Santa Maria do Rio Doce e Santa Joana/ES. Dissertação de Mestrado em Geografia. Universidade Federal do Espírito Santo. 2013.

MERTEN, G. H. et. al.. Considerações sobre a utilização da curva-chave de sedimentos para determinação de fluxo de sedimentos. In: MERTEN, G. H. et. al. (Ed.), Sedimentos: O Desafio da Multidisciplinaridade. Porto Alegre, ABRH, 2006.

MINELLA, J. P. G. Utilização de técnicas hidrossedimentométricas combinadas com a identificação de fontes de sedimentos para avaliar o efeito do uso e manejo do solo nos recursos 
hídricos de uma bacia hidrográfica rural no Rio Grande do Sul. Tese de Doutorado. Programa de Pós-Graduação em Recursos Hídricos e Saneamento Ambiental. Universidade Federal do Rio Grande do Sul. 2007.

MINELLA, J.P.G.; WALLING, D.E.; MERTEN, G.H. Combining sediment source tracing techniques with traditional monitoring to asses the impact of improved land management on catchment sediment yields. Journal of Hydrology. v. 348, 2008.

MOTA, A. R. P.; CARDOSO, M. E. S.; SANTOS, D. H. Erosão e conservação dos solos na microbacia do córrego do Veado. Colloquium Agrarie: Presidente Prudente, v. 4, nº 1, 2008.

MOURA, L. H. A. Estudo geoquímico da bacia do Gama e avaliação da qualidade da água. Dissertação de Mestrado. Instituto de Geociências. Universidade de Brasília. 2010.

MOURA, L. H. A., BOAVENTURA, G. R. \& PINELLI, M. P. A Qualidade de água como indicador de uso e ocupação do solo: Bacia do Gama - Distrito Federal. Instituto de Geociências, Universidade de Brasília, Brasília - DF, Brasil. Química Nova, v. 33, nº 1, 2009.

PAIVA, J. B. D.; PAIVA, M.C.D.; PARANHOS, R.M.; EMMER, R. Curva-chave de vazões e sedimentos em pequenas bacias hidrográficas. IV Encontro Nacional de Sedimentos. Porto Alegre, ABRH, 2001.

PIMENTEL DA SILVA, L.; URPIA ROSA, E.; PIRES DA SILVA, C.P. Parâmetros físicos e do saneamento ambiental de bacia experimetal-representativa na baixada de Jacarepaguá, Rio de Janeiro, Brasil. In: Ambiente \& Água - An Interdisciplinary Journal of Apllied Science, v. 5 - Universidade de Taubaté - Taubaté, Brasil. 2010.

PAZ, V. P. S.; TEODORO, R. E. F. T.; MENDONÇA, F. C. Recursos hídricos, agricultura irrigada e meio ambiente. Revista Brasileira de Engenharia Agrícola e Ambiental, v.4, $\mathrm{n}^{\mathrm{o}} .3$, Universidade Federal da Paraíba. Campina Grande, PB, 2000.

PISSARRA T. C. T, POLITANO W.; FERRAUDO A. S. Avaliação de características morfométricas na relação solo-superfície da bacia hidrográfica do córrego Rico, Jaboticabal (SP). Revista Brasileira de Ciência do Solo, 2004.

PHILLIPS, J. M.; RUSSELL, M. A.; WALLING, D. E. Time-integrated sampling of fluvial suspended sediment: A simple methodology for small catchments. Hydrological. Processes. 2000.

POLETO, C., e MERTEN, G. H. Rede de monitoramento e coleta de amostras. Qualidade dos Sedimentos, ABRH, ed., Porto Alegre, v. 397, 2006.

PORTO, R.; FILHO, K.; SILVA, R. Apostila de hidrologia aplicada. Desenvolvida pela Escola Politécnica da Universidade de São Paulo no departamento de engenharia hidráulica e sanitária, 2001. Disponível em: $<$ http://www.unilasalle.edu.br/canoas/assets/upload/eng_ambiental/medicaodevazaoecurvach ave.pdf $>$. Acessado em 14/06/2015.

RICHARDSON, J. F. e ZAKI, W. N. The sedimentation of a suspension of uniform spheres under conditions of viscous flow. Chemical Engineering Science. v. 8, 1954. 
ROIG, H. L. Modelagem e Integração de Dados Aplicados à Análise dos Processos Erosivos e de Transporte de Sedimentos - O Caso da Bacia do Rio Paraíba do Sul - SP. Tese de Doutorado em Geologia. Instituto de Geociências da Universidade de Brasília, Brasília-DF, 2005.

ROBINSON, M. \& WHITEHEAD, P. G. A review of experimental and representative basin studies in methods of hydrological basin comparison - Natural Environmental Research Council. University of Oxford, 1992.

SANTOS, D. A. R.; MORAES, F. Análise morfométrica da bacia hidrográfica do rio Lago Verde como subsídio à compartimentação do relevo da região de Lagoa da Confusão - TO. Revista Geonorte, ed. especial, v.3, 2012.

SANTOS, I. D., FILL, H. D., SUGAI, M. R. V. B., BUBA, H. KISHI, R. T, MARONE, E. e LAUTERT, L. F. Hidrometria Aplicada. Instituto de Tecnologia para o Desenvolvimento, Curitiba, 2001.

SANTOS, L. G.; MAGIOTTO, S. R.; VASCONCELLOS, V. L. D.; EVANGELISTA, B. A.; D’ANGIOLLELA, G. Cenários de mudanças climáticas e variações do balanço hídrico do Distrito Federal. XVII Congresso Brasileiro de Agrometeorologia Guarapari, ES. 2011.

SCHEIDEGGER, A. E. Hydrogeomor-phology. Journal of Hydrology, nº. 20, 1973.

SIGNELL. R. P. W. Transient eddy formation around headlands. Journal of Geophysical Research. 2012.

SILVA, M. M. da. Dinâmica espaço-temporal das áreas de afluência da bacia do córrego cavalheiro, 2012.

SILVEIRA, A.L.L. Ciclo hidrológico e bacia hidrográfica. In: Tucci, C.E.M. Hidrologia: ciência e aplicação. 2a ed. Porto Alegre: Ed. Universidade/UFRGS: ABRH. 2009.

SIMÕES, S. J. C; BERNADES, G. P.; NUNES, C. M. F.; MARCH, T. C. Variabilidade espacial do potencial de erosão e seus efeitos na sedimentação de um pequeno reservatório - A Bacia dos Mottas, Sudeste do Brasil. Revista Brasileira de Recursos Hídricos. v. 12 nº.3. 2007.

SIMÕES, S. J. C.; COIADO, E. M. Métodos de Estimativa de Sedimentos em Pequenas Bacias Hidrográficas, in: Hidrologia aplicada a gestão de pequenas bacias hidrográficas. Porto Alegre, ABRH, 2001.

STEINKE, E.T. Considerações sobre variabilidades e mudança climática no Distrito Federal, suas repercussões nos recursos hídricos e informação ao grande público. Tese de Doutorado. Universidade de Brasília. Instituto de Biologia. Departamento de Ecologia. 2004.

STRAHLER, A. N. Hypsometric (area-altitude) - Analysis of Erosion Altopography. Geological Society of America Bulletin, v. 63, $\mathrm{n}^{\circ} .11,1952$.

STRAHLER, A.N. Quantitative analysis of watershed geomorphology. New Halen: Transactions: American Geophysical Union, 1957. 
SUMMERFILD, M. A. Global Geomorphology: an Introduction to the Study of Landforms. Longman Scientific \& Technical, 1991.

TOMAZ, P. Transporte da carga total de sedimentos em rios de pequeno porte pelo Método de Yang, 1973. In: Curso de Manejo de águas pluviais. Cap. 95. 2013.

TONELLO, K. C. et. al. Morfometria da bacia hidrográfica da cachoeira das Pombas, Guanhães, MG. Revista Árvore, Viçosa-MG, v.30, nº.5, 2006.

TUCCI, C. E. M. Hidrologia: ciência e aplicação. Universidade Federal do Rio Grande do Sul, Porto Alegre, RS, 2013.

TUCCI, C. E. M.; MENDES, C. A. Avaliação ambiental integrada de bacia hidrográfica. Ministério do Meio Ambiente. Brasília: MMA, 2001.

UNITED STATES GEOLOGICAL SURVEY. The Water Cicle. Disponível em: $<$ http://water.usgs.gov/edu/watercycleportuguese.html $>$. Acessado em: 07/06/2015.

VILLAS-BOAS, M. D.; CHAVES, C. F. B.; SANTOS, F. J.; SILVA, J. G. P.; HENRIQUES, M. P.; MONTEIRO, A. E. G. C. Avaliação preliminar da qualidade da água nas bacias experimentais e representativa do rio Piabanha a partir do cálculo do índice de qualidade de água - IQA. XIX Simpósio Brasileiro de Recursos Hídricos. Maceió. 2011.

VILlELA, S. M.; MATTOS, A. Hidrologia aplicada. São Paulo: McGraw - Hill do Brasil. 1975.

WISLER, C. O.; BRATER, E. Hidrologia. Rio de Janeiro, RJ: Ao Livro Técnico. 1964.

WORLD METEOROLOGICAL ORGANIZATION. Lower tropospheric data compatibility: Low-level intercomparison experiment (Boulder, United States, 1979). Instruments and Observing Methods Report nº. 3, Geneva. 1980. 


\section{APÊNDICE}

\section{A - Descrição Ampliada dos Materiais e Métodos Utilizados}

\section{A.1 - Obtenção dos Parâmetros Meteorológicos, do Nível e da Vazão nos Trechos Analisados}

Os dados pluviométricos foram adquiridos junto a ANA no site HIDROWEB. Esta página é mantida pela própria agência, onde está disponível toda série histórica das estações pluviométricas instaladas no território nacional.

Em contrapartida a CAESB também mantém algumas estações pluvio-fluviométricas dentro do Distrito Federal, os dados disponíveis das estações foram disponibilizados pelos responsáveis e verificados pela pesquisadora. São dados de boa qualidade e foram consistidos pelos próprios funcionários desta companhia.

A aquisição destes dados meteorológicos caracterizou-se por ser a primeira fase desta pesquisa, a partir desta etapa foi possível verificar algumas das limitações incisivas à pesquisa, tal como os poucos dados meteorológicos disponíveis para a bacia hidrográfica do Ribeirão do Gama, muitos destes dados apresentavam inconsistências e longos períodos sem mensuração.

Desta forma foi realizada a sistematização das estações viáveis à pesquisa, assim, de trinta e quatro (34) estações pluviométricas disponibilizadas pela CAESB restou apenas uma (1) para ser analisada durante a pesquisa e outras duas (2) da ANA. Destas três (3) definiu-se as melhores, a fim de abranger as áreas de coleta sedimentar, com o objetivo de possibilitar melhores correlações entre as variáveis chuva, vazão e carga sedimentar, abaixo segue a localização das estações: 


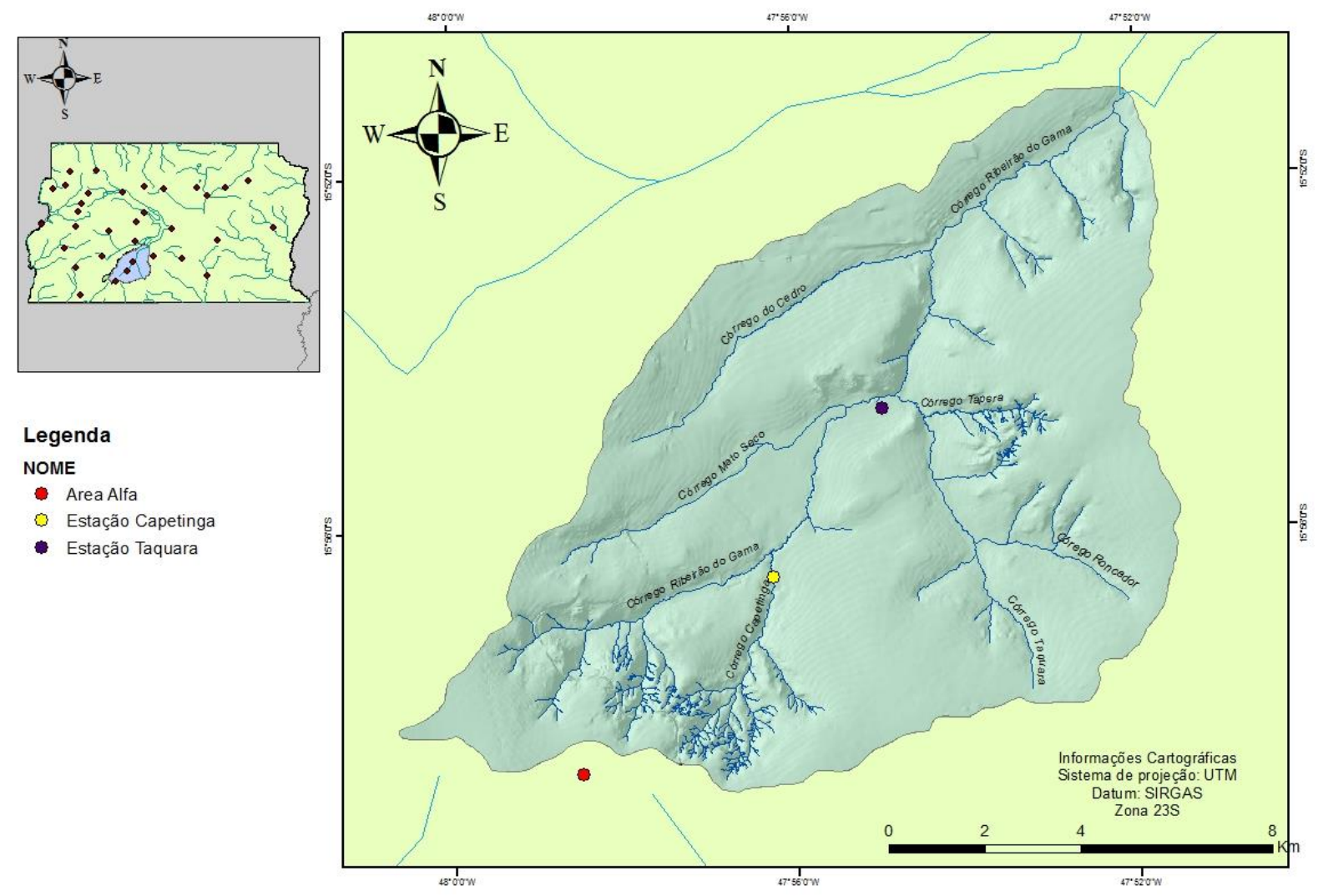

Figura 31: Estações utilizadas na pesquisa.

As estações pluvio-fluviométrica dos córregos Taquara e Capetinga foram instaladas pela pesquisadora durante o ano de 2013 em parceria com a ANA, CAESB e FAL-UnB, onde a ANA forneceu as Plataformas de Coleta de Dados - PCD, com painéis solar; a CAESB auxiliou com as réguas linimétricas e o cercado de proteção das estações; a FAL - UnB colaborou com materiais, tal como madeira para as pontes e mão-de-obra.

As PCD's além de mensurar os índices pluviométricos também captam o nível fluviométrico dos córregos, uma vez que nelas está instalado um sensor de nível (Córrego Taquara) e um radar (Córrego Capetinga), ambos equipamentos inferem o nível dos córregos a cada 15 minutos.

Não obstante, para inferir a vazão dos corpos hídricos estudados foi necessário estabelecer uma logística em parceria o PTHAR, pois não há equipamento disponível que mensure esta variável de forma automática sem a presença de um operador, desta forma foi organizada uma agenda onde se estabeleceu uma campanha por mês para adquirir os dados de descarga líquida (vazão) e a descarga sólida (carga sedimentar em suspensão), buscou-se ainda 
realizar campanhas em eventos de cheia, todavia esta foi prejudicada pela falta de transporte e auxílio em campo.

\section{A.2 - Instrumentalização das Estações Córrego Taquara e FAL - UnB}

Caracterizando a segunda etapa desta pesquisa tem-se a estruturação e instalação das estações pluvio-flúviometricas dos córregos Taquara e Capetinga, localizadas dentro da área da Fazenda Experimental Água Limpa - UnB, as estações possuem as seguintes referências geográficas:

- Estação Córrego Taquara (1554'40"S, 47054'32"O) e;

- Estação FAL-UnB (1556’42”S, 4756’18”O).

A instalação destas estações seguiu as orientações explanadas no relatório de instalação de estações hidrométricas da Agência Nacional de Águas (2011) e dos critérios trazidos por Santos et. al. (2001). Estes trabalhos ressaltam que as estações deviam ser instaladas em terreno plano, relativamente protegido, livre de obstáculos e de riscos de inundações, com a superfície de captação do pluviômetro em um plano horizontal, não apresentando deformações, além de estar a uma altura de 1,5 metros acima do solo. Os obstáculos deverão estar a uma distância igual ou superior a duas vezes a altura do obstáculo com relação à superfície de captação dos pluviômetros, abaixo segue modelo:

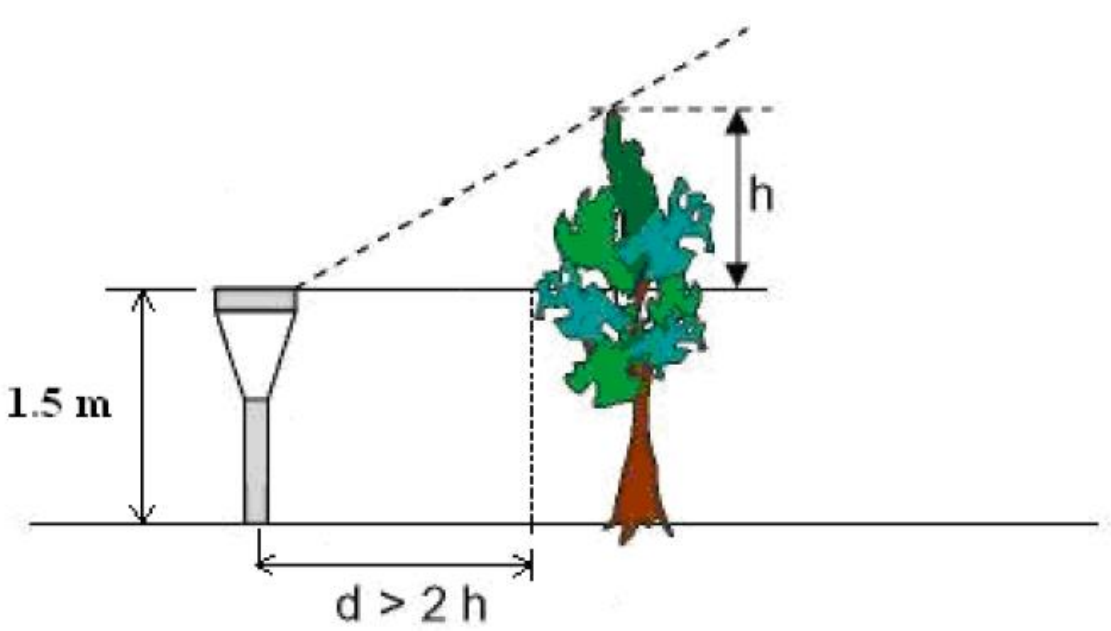

Figura 32: Esquema de posicionamento do pluviômetro em relação aos obstáculos. Fonte: ANA, 2011. 
Toda instalação foi acompanhada pelos agentes da ANA, a qual concedeu dois pluviôgrafos, um para cada estação, um radar para mensuração de nível, o qual está instalado na estação FAL-UnB, um sensor de nível, instalado da estação Córrego Taquara. Juntamente com as estações também foi necessária a construção das pontes sobre os córregos, pois não havia estrutura alguma para este tipo de pesquisa. As pontes foram instaladas pela própria FALUnB, esta cedeu tanto o material quanto a mão-de-obra para a construção.

Seguem as fotos da construção e instalação das estações pluvio-fluviométricas na FAL - Unb: 


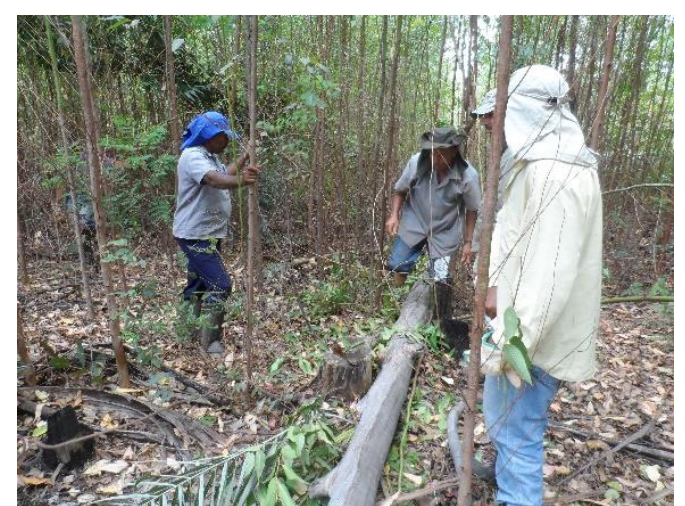

Figura 33: Escolha das árvores para confecção das pontes - córrego Taquara e Capetinga.

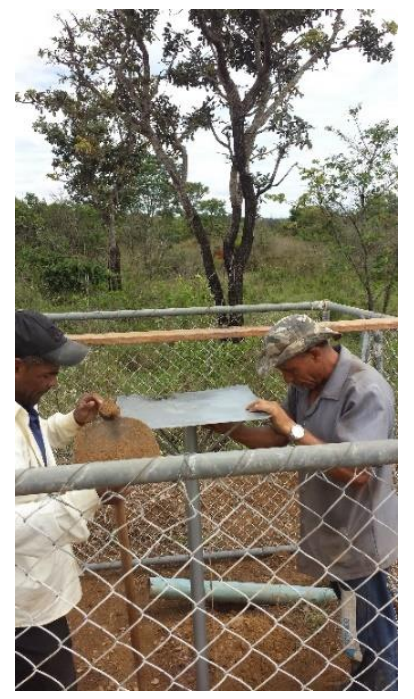

Figura 35: Instalação estação pluviométricafluviométrica - córrego Taquara

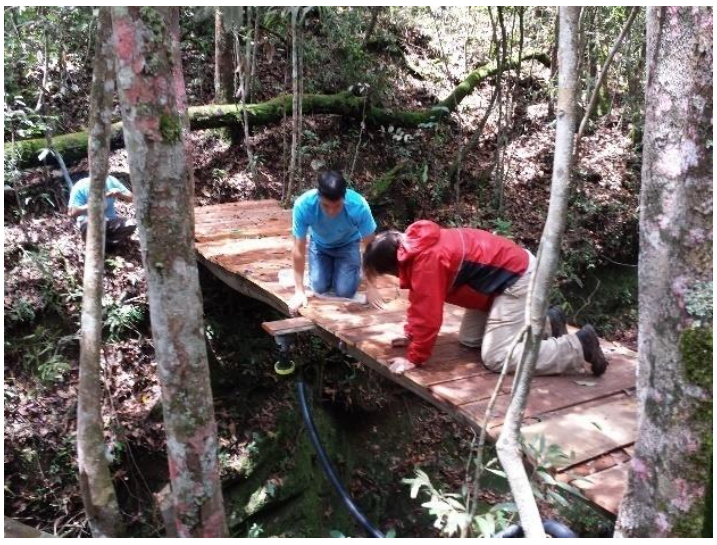

Figura 37: Instalação radar e ponte concluída córrego Capetinga.

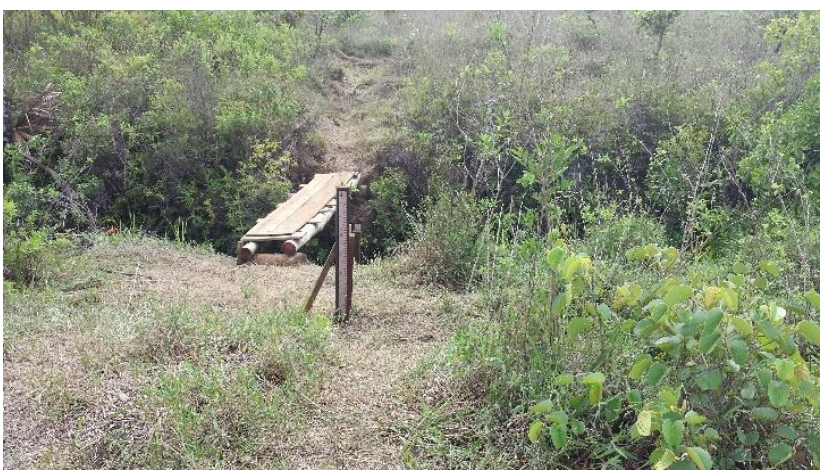

Figura 34: Ponte córrego Taquara.

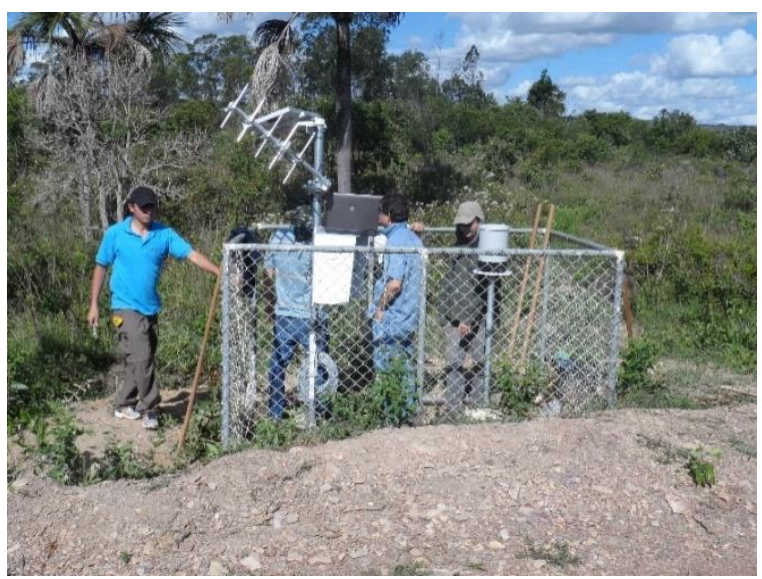

Figura 36: Técnicos da ANA auxiliando na instalação da estação córrego Taquara.

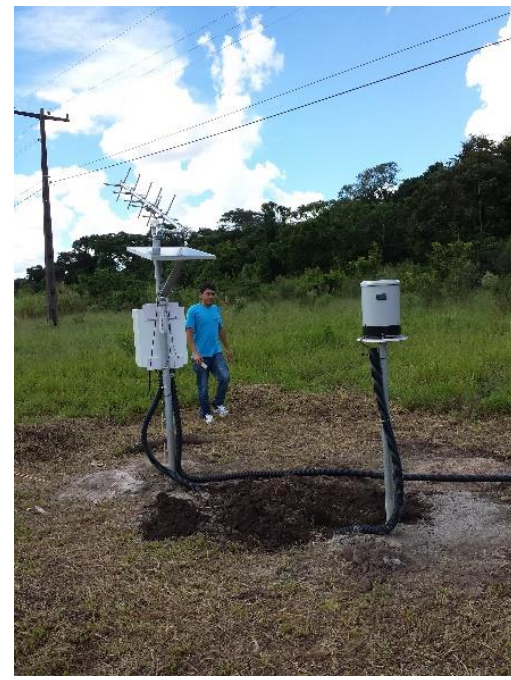

Figura 38: Instalação estação pluviométrica e fluviométrica - córrego Capetinga. 


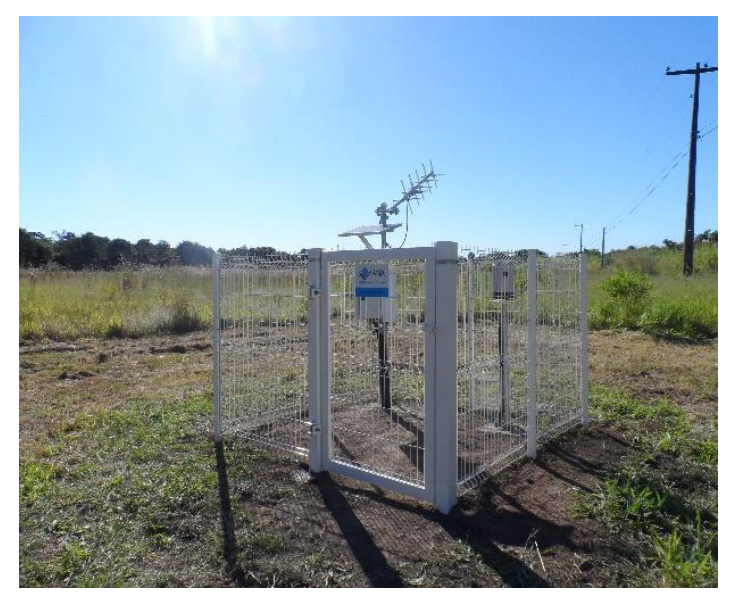

Figura 39: Estação FAL - UnB concluída.

É necessário frisar, que os medidores de nível devem ser instalados em locais fixos sem chances de oscilação em relação à altura, pois necessitam ficar estáticos para realizarem leituras precisas do nível da coluna d'água.

Outro instrumento importante e indispensável em estações fluviométricas são as réguas linimétricas, desta forma foram instalados lances de réguas linimétricas em ambas estações. As réguas utilizadas nas seções foram cedidas pela CAESB e são do material alumínio anodizado e suas disposições são de $1 \mathrm{~m}$ em $1 \mathrm{~m}$. Este padrão de régua foi criado pelo antigo Departamento Nacional de Águas e Energia Elétrica - DNAEE, as quais foram inspiradas no modelo de ferro esmaltado.

Finalizada as instalações seguiu-se com a coleta dos dados captados pelas Plataformas de Coleta de Dados - PCD's, verificação da confiabilidade do dado e seu adequado funcionamento em campo. A aquisição dos dados capturados pelas PCD's pode-se dar por duas vias, uma em campo diretamente na PCD ou pela base de dados online da ANA, pois os dados são transmitidos diretamente para o sistema informacional da agência via satélite, onde são disponibilizados para todos que o quiserem acessar.

Este serviço via web da ANA funciona como um banco de dados online, o qual abriga toda série histórica das estações conveniadas a ela. O funcionamento deste sistema dá-se da seguinte forma: os dados são recebidos via WebService, que são armazenados com segurança nas bases de dados da ANA, sendo posteriormente qualificados e disponibilizados ao público a partir do portal do Sistema Nacional de Recursos Hídricos - SNIRH, localizado no endereço: http://www.ana.gov.br/portalsnirhe de fácil acesso e aquisição. 


\section{A.3 - Dificuldades na Coleta dos Dados em Campo}

Concomitante a coleta de dados pluviométrico e de nível buscou-se realizar as mensurações das descargas sólidas e líquidas nos pontos de coleta, esta etapa foi a que mais exigiu esforço, visto que é a mais problemática, pois demanda logística muito bem definida, pessoal, equipamentos calibrados e previamente testados, ademais de recursos financeiros.

Todavia, no total, foram realizadas oito (8) campanhas de campo, todas em conformidade com os manuais da ANEEL - Agência Nacional de Energia Elétrica e ANA. Não obstante, não foi possível realizar mais campanhas devido à falta de transporte, pessoal e equipamentos disponíveis, pois estes estavam sendo utilizados/compartilhados pelos alunos do PTHAR, do Instituto de Geociências e pelo Departamento de Geografia, ou seja, algumas vezes houve choques de agenda, que inviabilizaram a realização de mais campanhas de monitoramento.

A questão do transporte foi uma problemática a ser superada, pois as áreas estudadas eram distantes da Universidade e também distantes entre si, fato que impossibilitou, muitas vezes as visitas e campanhas, pois necessitava transportar grande quantidade de equipamentos e estes, em sua maioria, são grandes e pesados. Esta fase foi contornada com o auxílio do PTHAR, o qual cedeu carro que o departamento possui para as pesquisas de campo; o sistema de transportes da UnB também foi útil, pois viabilizou algumas campanhas; apesar de que este, incontáveis vezes, não compareceu ao local marcado.

Concomitante houvera a dificuldade de encontrar recursos humanos disponíveis para realizar as atividades em campos, pois como é exposto no Manual de práticas hidrossedimentológicas, são necessários ao menos uma dupla de pessoas para realizar as campanhas. O LAGEF disponibilizou alguns estagiários para auxiliar nas campanhas, medida que possibilitou o prosseguimento desta pesquisa, entretanto, tantas outras campanhas deixaram de ser realizadas pela incompatibilidade de horários entre os estagiários e a necessidade de campo.

Ademais, durante o desenvolvimento deste trabalho ocorreu a perda de alguns dados de vazão e nível, fato que corroborou para a inconsistências das curvas-chave e a imprecisão dos resultados obtidos, todavia os dados obtidos são de grande valia, pois estes são inéditos para as áreas do Córrego Capetinga e para o Córrego Taquara, além de abrir caminho para outros pesquisadores. 


\section{A.4 - Instrumentos Utilizados nas Campanhas}

\section{Acustic Digital Current - ADC}

Para a obtenção da vazão utilizou-se o Acustic Digital Current (ADC), o qual é ideal para medições de fluxo em cursos d'água de pequeno e médio porte. As drenagens podem ser classificadas de acordo com a média anual da profundidade da seção fluviométrica. Desta forma o ADC foi classificado como um equipamento eficiente e preciso para esta pesquisa.

O funcionamento deste equipamento constitui-se de um sensor de pressão acoplado no molinete o qual captura a profundidade do local, permitindo assim o perfilamento da seção do córrego e o cálculo automático da vazão ao final da medição, as seções de medição são previamente estabelecidas ao se inserir a largura do canal, ou seja, o ADC divide automaticamente as áreas de medição.

Ademais, é possível ajustar a quantidade de pontos a ser mensurado em cada seção e a velocidade de mensuração de cada ponto, desta forma, para as seções verificados foi estabelecido as velocidades de mensuração seria de 15 segundos em cada ponto e foram verificados dois pontos em cada seção, um próximo ao leito e outro próximo a superfície, finalizada esta etapa o equipamento faz a soma das velocidades médias de cada vertical e apresenta a vazão do curso hídrico.

$$
\begin{gathered}
Q=A . V \\
Q=m^{2} \cdot m / s \\
Q=\frac{m^{3}}{s} \\
\sum V m \cdot A v=\text { Qrio }
\end{gathered}
$$

Onde:

$Q$ é a vazão;

$\boldsymbol{A}$ é área da seção molhada;

$\boldsymbol{V}$ é a velocidade;

$\boldsymbol{V} \boldsymbol{m}$ é a velocidade média e;

$A v$ é a área das verticais.

Para os dois córregos (Taquara e Capetinga) o equipamento sugeriu a tomada de vazão em oito verticais, sendo de $30 \mathrm{~cm}$ a distância de uma seção para outra, pois os canais são de pequeno porte, apresentando largura, de uma margem a outra, de aproximadamente 2,5m, 
todavia só é possível a tomada de sete verticais devido a lâmina d'água ser muito baixa nas proximidades da margem direita em ambos os córregos.

Já para o Ribeirão do Gama que variava de seção conforme o nível linimétrico apresentava largura de uma margem a outra entre seis (6) a oito (8) metros, desta forma a quantidade de seções a serem realizadas as mensurações variavam, entretanto, cada seção era espaçada em $60 \mathrm{~cm}$ cada, pois este é um rio maior, considerado de médio porte.

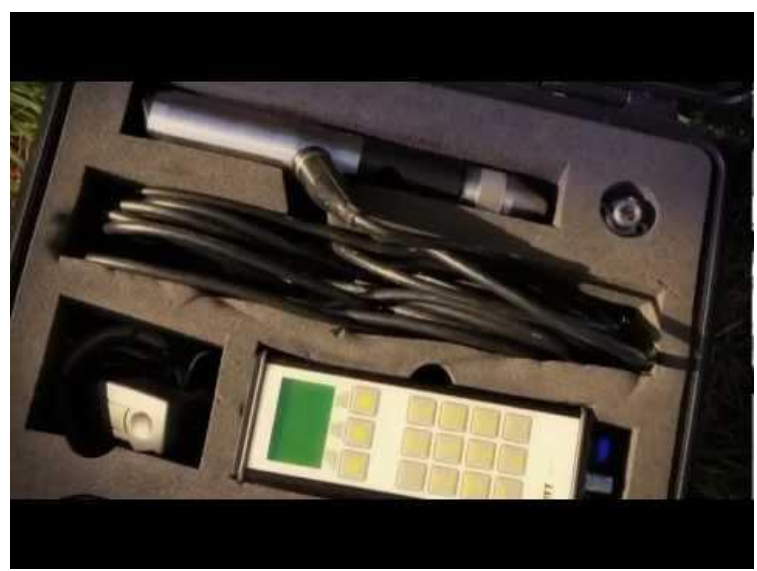

Figura 40: Acustic Digital Current - ADC.

\section{ADC - Acoustic Digital Current Meter - Qlinner 2}

Outro equipamento utilizado para mensurar a vazão foi o ADCQlinner, também conhecido como catamarã ou Qlinner 2, este segue o mesmo padrão de mensuração do ADC descrito acima, ou seja, apresenta um sensor acoplado na parte inferior no aparelho que realiza as medições de forma semi-automática. O Qlinner 2 da empresa OTT utiliza tecnologia doppler para medição de vazão móvel em rios e canais, a medição é realizada utilizando o processo clássico das verticais, onde o hidrometrista insere a largura do rio de uma margem a outra e o próprio aparelho estabelece a quantidade de seções a serem mensuradas. 


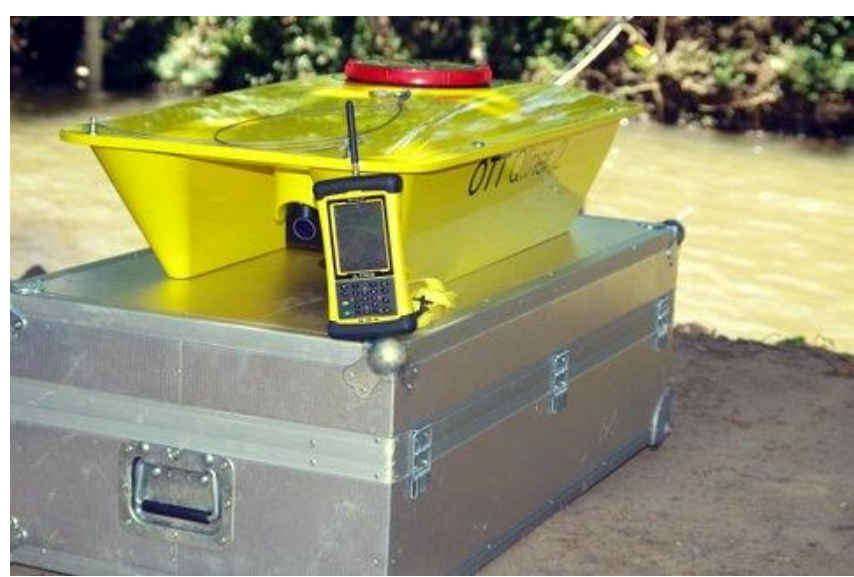

Figura 41: Acustic Digital Current - ADC - OTT Qlinner 2.Fonte: Bruno Távora.

Nas verticais sugeridas, o Qlinner 2 realiza duas medições simultaneamente, que são: a velocidade de cada seção e a profundidade desta. Todos os dados medidos são transferidos para o PDA (Palmtop) via Bluetooth. Concluída a medição a descarga estará disponível imediatamente e a faixa de medição é de aproximadamente $10 \mathrm{~m} / \mathrm{s}$. O Qlinner 2 pode ser facilmente operado em formas de cabo, a partir de pontes ou a partir da borda dos rios ou canais.

\section{Amostrador USDH-48}

Este equipamento é utilizado para proporcionar a realização das coletas de sedimentos em suspensão, todavia é adequado para coletas em vazões menores. As amostras foram coletadas em garrafas de vidro com capacidade de 1 litro, este aparelho é um integrador na vertical para coleta de amostras em corpos hídricos de até $1,5 \mathrm{~m}$ de profundidade, sendo calibrada para um bico de 1/4. A garrafa fica acomodada no equipamento em um ângulo de $45^{\circ}$.

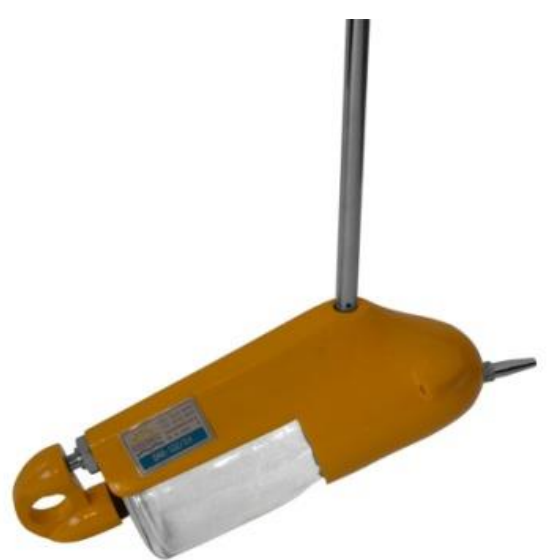

Figura 42: Amostrador USDH - 48. 
A finalidade deste método é a obtenção de amostras representativas da mistura águasedimento em movimento no fluxo nas várias verticais, para o seu uso é necessário apenas definir a metodologia a ser aplicada em campo e manter atenção ao tempo de descida que deve ser igual ao de içamento, de forma a ser constante, tomando cuidado para que o equipamento não toque o leito do rio.

\section{Amostrador USDH-59}

Este amostrador é mais utilizado em rios que apresentam descarga líquida mais elevada e para eventos de cheias, pois possui aerodinâmica mais estável em água e peso superior ao USDH-48. Nesta pesquisa este equipamento foi manuseado manualmente por meio de cabo, há possibilidade de utilizá-lo com guincho acoplado em barcos ou pontes.

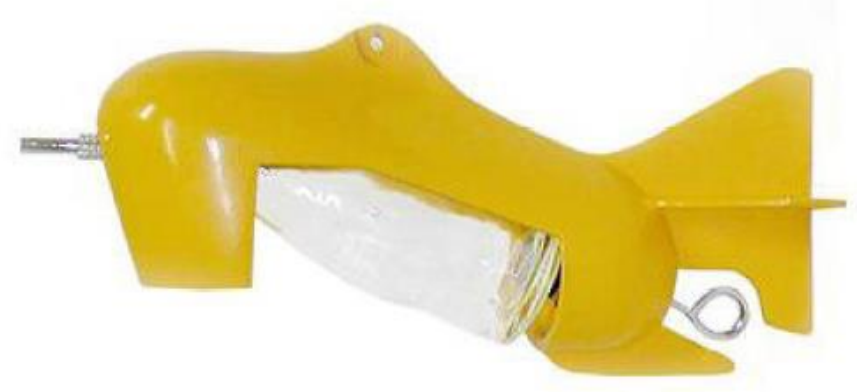

Figura 43: Amostrador USDH-59.

Este tipo de amostrador é do padrão leve, utiliza garrafa de 1litro, segue a mesma regra de manuseio do amostrador USDH-48 descrito acima. Ele foi fabricado para uso com cabo em suspensão, apresentando algumas facilidades maiores que o USDH-48, pois pode ser usado a vau, encima de uma ponte ou de barco, em rios com velocidade até $1,5 \mathrm{~m} / \mathrm{s}$. este é ainda integrador na vertical para profundidades de até quase $5 \mathrm{~m}$, possui três bicos calibrados para 1/8", 3/16" e 1/4" que são usados conforme as profundidades e a velocidade da corrente.

\section{Amostrador Automático ISCO 6712}

O ISCO 6712 é um amostrador do tipo automático, ou seja, não necessita da presença humana para que funcione, bastando apenas sua programação prévia. Este amostrador é 
composto por uma bomba veloz, que, originalmente foi desenvolvida para sugar águas residuais, entretanto as águas residuais, normalmente, não carregam quantidades significativas de sedimentos. Portanto, a representação da distribuição de partículas não era um critério considerado, durante as fases de concepção e ensaio do equipamento.

O amostrador possui um dispositivo elétrico que impulsiona a bomba peristáltica, que é ativado em um horário pré-determinado por um temporizador interno ou a ativação ocorre devido a mudança no nível da lâmina d'água. O tubo de entrada é purgado antes e depois de cada período de bombeamento por inversão automática da bomba, isto pode ser determinado nas configurações prévias.

Nesta pesquisa foram alcançados 11 eventos de cheia com o amostrador ISCO 6712, não foi atingido número maior, pois houve dificuldade do tipo estrutural na instalação deste em campo.

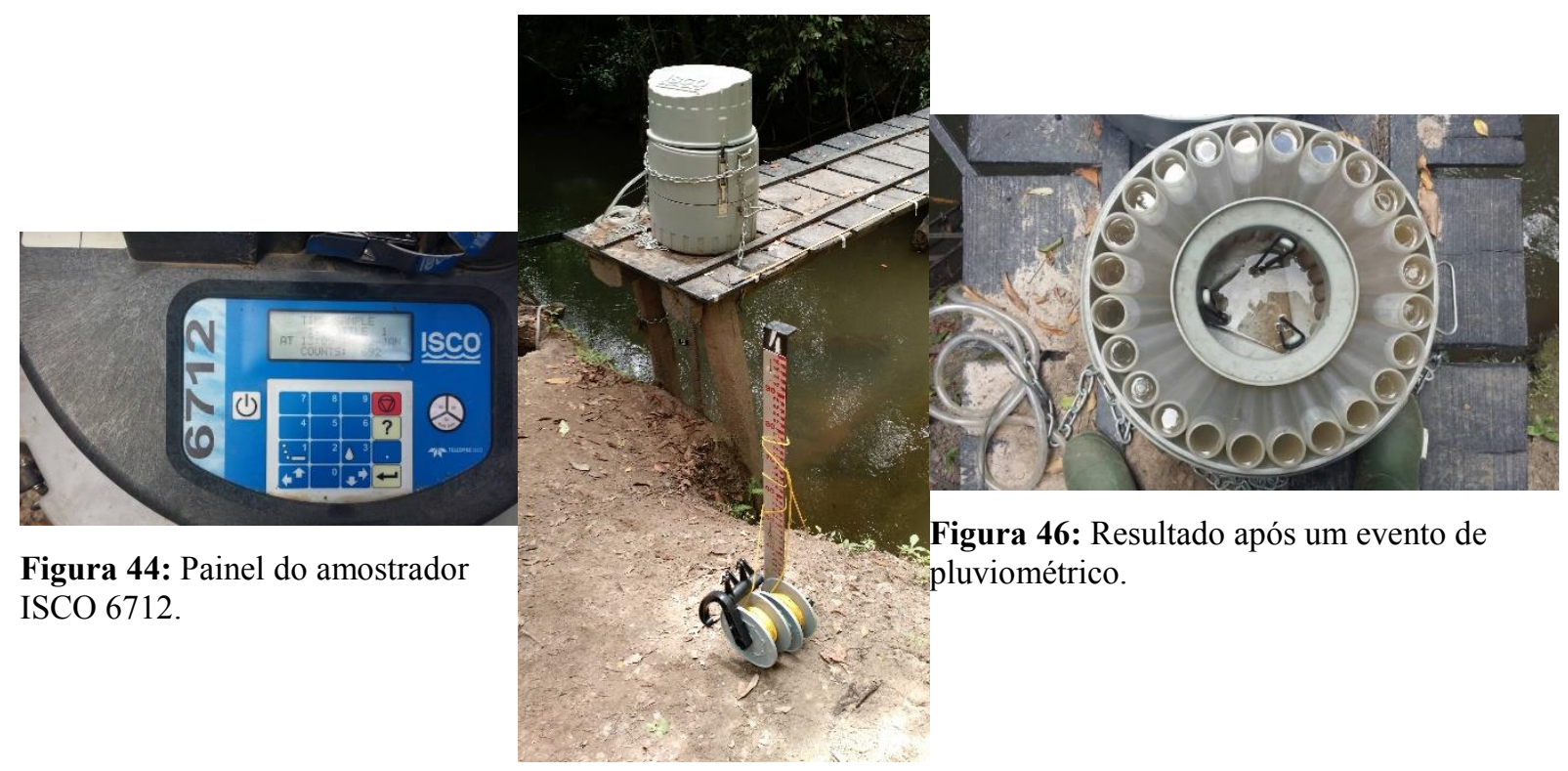

Figura 45: Amostrador instalado no Ribeirão do Gama.

\section{Réguas Linimétricas}

As réguas utilizadas são fabricadas em alumínio anodizado e os lances destas estão dispostos de $1 \mathrm{~m}$ em $1 \mathrm{~m}$. Este padrão de régua foi criado pelo antigo DNAEE, foram inspiradas no modelo de ferro esmaltado, sendo útil para medir o nível da lâmina d'água. 


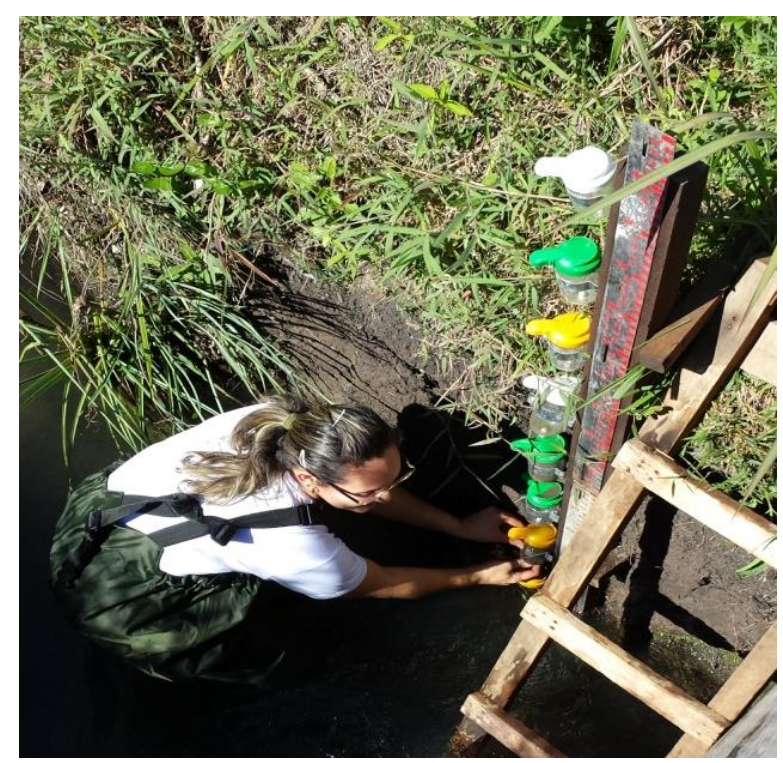

Figura 47: Réguas linimétricas instaladas.

\section{Plataforma de Coleta de Dados}

Uma PCD é um dispositivo automatizado que dispõe de sensores eletrônicos capazes de medir diversas variáveis ambientais, tais como precipitação, pressão atmosférica, radiação solar, temperatura, detecção da variação dos níveis de corpos de água, dentre outras varáveis, bastando apenas a instalação destes sensores e sua configuração nas PCDs.

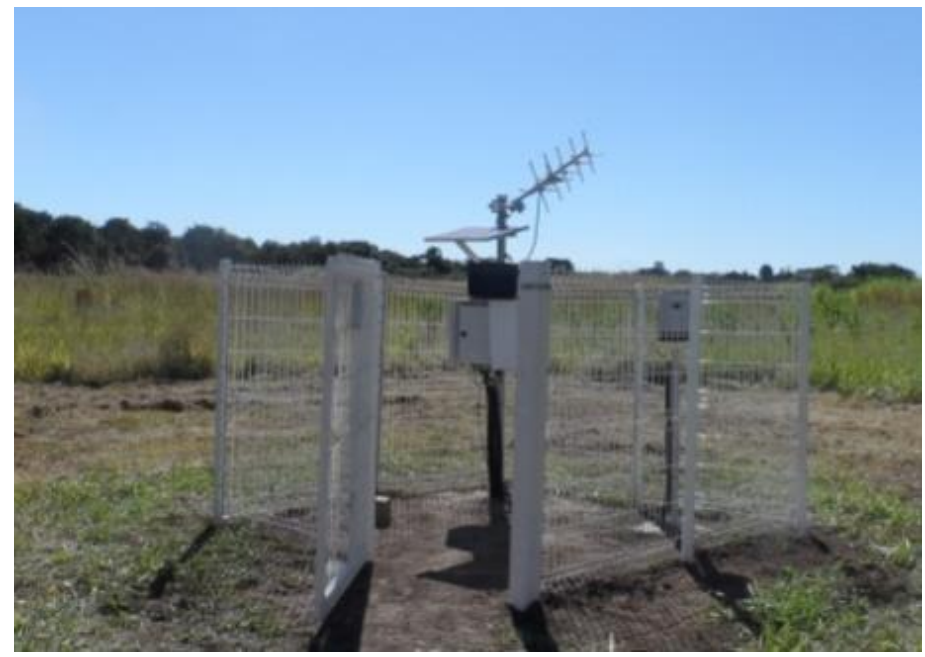

Figura 48: Plataforma de coleta de dados.

Como as duas estações pluvio-fluviométricas foram instaladas com auxílio da ANA seguiram-se todas as especificações e normas técnicas exigidas por esta agência. As PCDs 
possuem uma antena de transmissão que enviam os dados via satélite para a ANA, podendo ser baixados em tempo real no site do SNIRH e o sistema operacional desta plataforma é o VAISALA, este é um programa simples e de fácil operação.

\section{Linígrafo com Data Logger}

Os linígrafos instalados nas seções do Ribeirão do Gama e Córrego Taquara são compostos de um sensor de nível, o qual é imerso totalmente na água e possui um cabo que se conecta a plataforma de coleta de dados - PCD, onde os dados são armazenados por um período de aproximadamente um ano. O cabo de ligação possui um duto de ar que faz compensação da pressão atmosférica, resultando assim o nível do corpo hídrico.

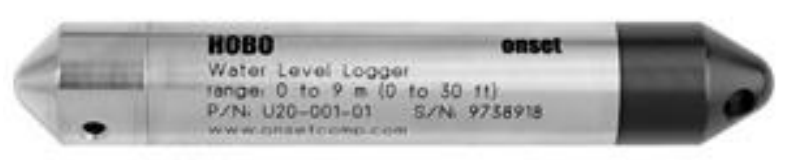

Figura 49: Linígrafo com data logger.

Os dados por ele adquiridos podem ser baixados utilizando cabos adaptadores, um software específico denominado VAISALA e um computador portátil, além de se poder fazer o download ou visualizá-los no site da Agência Nacional de Águas por meio do endereço eletrônico <http://mapas-hidro.ana.gov.br/Usuario/DadoPesquisar.aspx>.

\section{Sensor tipo Radar}

Este sensor tem a mesmo objetivo do linígrafo, entretanto este radar foi instalado no córrego Capetinga, o qual capta a altura da lâmina d'água a cada 15 minutos, ele é programável para frequência de leituras entre uma leitura a cada 30 segundos e uma leitura por dia; a faixa de medição é de 1 a $20 \mathrm{~m}$ e a faixa de exatidão é de $\pm 5 \mathrm{~mm}$ sobre todo o range de medida. 


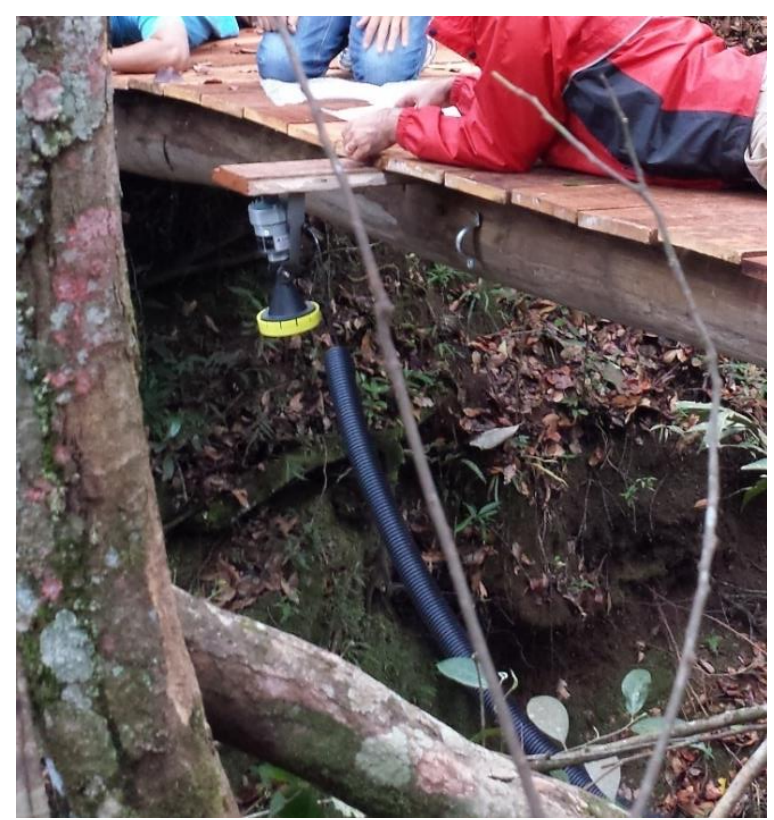

Figura 50: Sensor de nível tipo radar.

O ângulo total máximo de abertura é de $12^{\circ}$; a faixa de alimentação é de 9 a 16 volts ou amplitude superior; a conexão é via elétrica com cabo integral de poliuretano com os devidos conectores para ligação entre o sensor de nível e a PCD, moldado ou similar, e com 100 metros de comprimento; - Material do invólucro inoxidável e resistente às intempéries e o seu peso máximo é de $3 \mathrm{~kg}$.

\section{A.5 - Análise Laboratorial}

Compreende a etapa seguinte ao campo, ou seja, a coleta de dados in situ. Esta etapa é umas das que mais exige atenção e cuidado do pesquisador, pois cada passo interferirá no resultado final esperado. A primeira fase desta etapa inicia-se em campo com o armazenamento das amostras, onde seguiu-se os métodos estabelecidos por Edwards e Glysson (1999.

Após este procedimento, dirige-se para o laboratório, onde serão guardadas as amostras em lugar seco, com pouca ou nenhuma luz e sem vibrações, pois as amostras devem descansar por três a quatro dias, a fim de que todo material em suspensão decante.

Em seguida deve-se verificar o método de análise a ser aplicado, uma vez que este variará em relação a qualidade da amostra, a concentração do material e aos objetivos da pesquisa. Quando as amostras apresentam baixas concentrações de sedimento o método da filtração é o mais indicado, podendo ser aplicado ainda o método da evaporação, nesta pesquisa 
aplicou-se somente a filtração, vez que as amostras apresentavam baixa quantidade de sedimentos e pouca turbidez aparente.

O procedimento seguido foi bastante simples e rápido, inicialmente foi determinado o volume da amostra a ser utilizada, em seguida retirou-se o material sobrenadante com uma mangueira, tomando cuidado para que não toque no fundo e nem agite a amostra; adiante, utilizou-se um béquer para transferir todo o composto (líquido + sedimentos) para um recipiente que funciona com uma bomba a vácuo succionando o material através de um papel filtro com malha de $0,47 \mathrm{~mm}$ ou inferior, que deve ser secado em estufa a $100^{\circ} \mathrm{C}$ (no máximo) por 1 hora e pesado antes da filtragem.

O resíduo da filtragem presente no papel filtro foi levado à estufa, onde permaneceu cerca de 2 horas a uma temperatura em torno de $100^{\circ} \mathrm{C}$, depois o material foi introduzido no dessecador a vácuo até atingir a temperatura ambiente, para em seguida, ser pesado na balança de precisão e o valor obtido foi subtraído do peso inicial do filtro originando a concentração sedimentar. A concentração Cs é determinada pela razão entre o peso seco do sedimento (P) contido na amostra e o volume total utilizado (V).

$$
C_{s}=\frac{\mathbf{P}}{\mathbf{V}}
$$

Escolhido o método, este será aplicado para a determinação da concentração de sedimentos em suspensão (Css) no instante da medida, dada em mg.L $L^{-1}$. A concentração de sedimentos multiplicada pela vazão instantânea fornece a estimativa da descarga de sedimentos (Qss), que, integrada no tempo, fornece a estimativa da produção de sedimentos (ton. $/ \mathrm{km}^{2} / \mathrm{dia}^{-1}$ ) (Santos et al., 2001).

Segundo a Organização Meteorológica Mundial (WMO, 1981) os volumes necessários a uma correta análise com precisão adequada, são aqueles apresentados na tabela abaixo:

A seguir seguem imagens dos procedimentos laboratoriais desenvolvidos durante a pesquisa: 


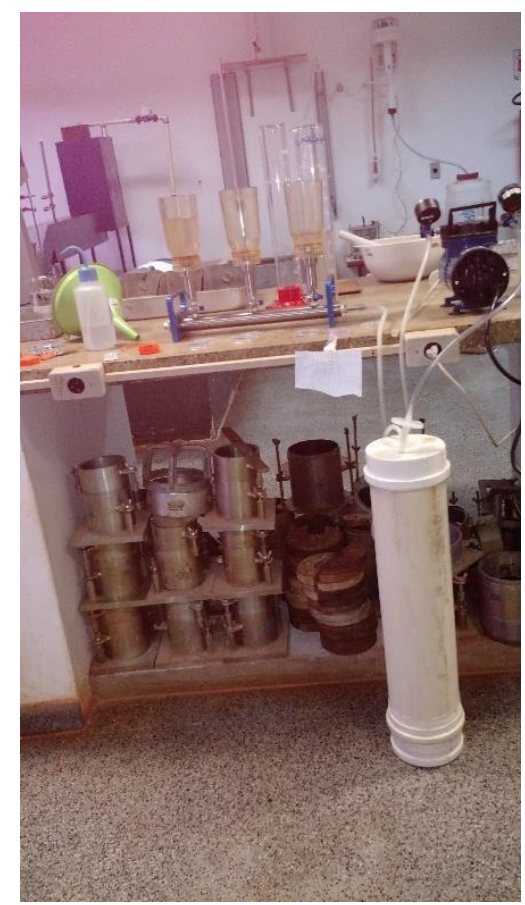

Figura 51: Estação para filtragem completa.

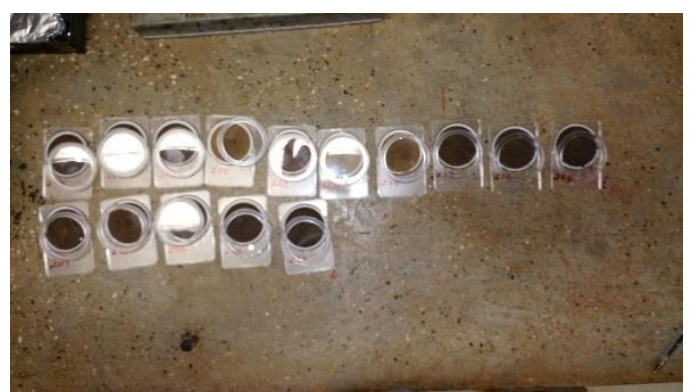

Figura 53: Petris com amostras filtradas (Ribeirão do Gama são as escuras e as mais claras são dos córregos Taquara e Capetinga).

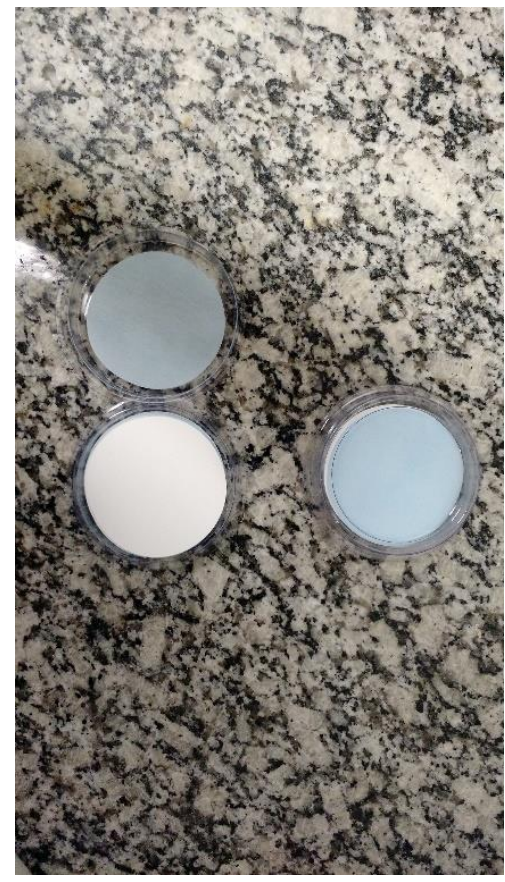

Figura 52: Filtros utilizados.

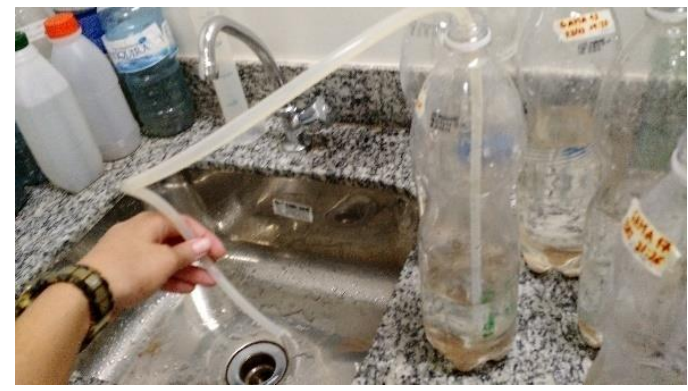

Figura 54: Retirada dos sedimentos sobrenadante. 


\section{Anexos}

1) Procedimento para Análise Sedimentométrica em Laboratório pelo Método da Filtração

\section{Objetivo:}

Este procedimento objetiva prescrever o método de análise sedimentométrica para a determinação quantitativa de sedimentos em amostras de água com turbidez abaixo de 200NTU pelo método da Filtração.

-Procedimento de Execução

- Balança analítica;

- Papel filtro $0,45 \mu \mathrm{m}$;

- Cápsula de porcelana;

- Espátula;

- Filtro;

- Pissete;

- Turbidímetro;

- Pipeta/mangueira;

- Estufa;

- Dessecador;

- Proveta graduada de 2L.

\section{- Preparação do papel filtro}

1- Lavar papéis de filtro com água destilada ou deionizada.

2- Transferir para estufa (com temperatura 103 e $\left.105^{\circ} \mathrm{C}\right)$, onde permanecerá por mais de 2 horas.

3- Transferir para um dessecador.

4- Retirar todo o ar do dessecador por meio de bomba a vácuo.

5- Esperar que o papel esfrie por 15 minutos e/ou até que resfrie.

6- Medir a massa do papel de filtro em balança analítica e anotar na planilha.

\section{- Determinação Sedimentométrica}

1- Realizar análise de turbidez da amostra (sem descartar nenhuma alíquota). 
2- Medir o volume da amostra em proveta de $2000 \mathrm{ml}$ (0,02 L). Retornar a amostra para o recipiente de origem, tendo o cuidado de, com o auxílio do pissete com água destilada, retirar todo sedimento que possa ter ficado nas paredes da proveta.

3- Deixar a mostra em repouso por, pelo menos, quatro dias, em local protegido da luz (caso o frasco seja transparente).

4- Com cuidado de não movimentar a amostra, retirar o líquido sobrenadante, utilizando o método de pipetagem ou sifonagem com mangueira (encha a mangueira de água, tape uma das extremidades com uma mão e insira, cuidadosamente, a outra extremidade na amostra) de forma a deixar a amostra com aproximadamente $200 \mathrm{ml}$.

5- Proceder à filtração da amostra utilizando o papel de filtro que foi previamente preparado, lavando o recipiente de origem com água destilada ou deionizada sem desperdiçar nenhuma alíquota.

6- Transferir o papel de filtro para a estufa (com temperatura entre 103 e $105^{\circ} \mathrm{C}$, onde deve permanecer por $1 \mathrm{~h}$.

7- Proceder com todo o processo de esfriamento do papel em dessecador com o auxílio da bomba de vácuo.

8- Medir a massa do papel filtro + sedimento em balança analítica e anotar em planilha.

Obs.: As equações utilizadas não estão dispostas aqui porque já foram explicadas acima. 